ФГБНУ «Научный Центр Психического Здоровья»

Министерство Здравоохранения Российской Федерации ФГБОУ ВО «Российский Национальный Исследовательский

Медицинский Университет имени Н.И. Пирогова» Обособленное Структурное Подразделение «Научно-исследовательский Институт Педиатрии имени Ю.Е. Вельтищева»

Министерство Здравоохранения Российской Федерации ФГБОУ ДПО «Российская Медицинская Академия Непрерывного Профессионального Образования»

Министерство образования и науки Российской Федерации ФГАОУ ВО «Белгородский государственный национальный исследовательский университет»

\author{
И.Ю. Юров, С.Г. Ворсанова, \\ В.Ю. Воинова, М.И. Чурносов, Ю.Б. Юров
}

\title{
ЦИТОГЕНЕТИЧЕСКИЕ, МОЛЕКУЛЯРНЫЕ И КЛИНИЧЕСКИЕ ОСНОВЫ ГЕНЕТИЧЕСКИ ОБУСЛОВЛЕННЫХ БОЛЕЗНЕЙ
}

\section{Учебное пособие}

Рекомендовано УМО РАЕ

в качестве учебного пособия

для студентов, ординаторов,

врачей, обучающихся по направлениям

подготовки по специальностям

31.08 .30 - «Генетика»;

31.08 .06 - «Лабораторная генетика»;

31.08.20 - «Психиатрия»;

31.08 .19 - «Педиатрия»

Москва 


\section{Рещензенты:}

Куцев С.И. - член-корр. РАН, доктор медицинских наук, профессор, директор ФГБНУ «Медико-генетический научный центр», зав. кафедрой молекулярной и клеточной генетики ФГБОУ ВО «РНИМУ им. Н.И. Пирогова» Минздрава России;

Ларионова В.И. - доктор медицинских наук, профессор кафедры педиатрии и детской кардиологии ФГБОУ ВО «Северо-Западный государственный медицинский университет им. И.И. Мечникова» Министерства здравоохранения Российской Федерации.

Цитогенетические, молекулярные и клинические основы Ц74 генетически обусловленных болезней: учебное пособие / И.Ю. Юров, С.Г. Ворсанова, В.Ю. Воинова, М.И. Чурносов, Ю.Б. Юров. - М.: Издательский дом Академии Естествознания, 2019. - 164 с.

\section{ISBN 978-5-91327-581-3 \\ DOI 10.17513/np.351}

Учебное пособие предназначено для ординаторов и студентов, получающих медицинское, биологическое, психологическое образование в соответствующих ВУЗах и постигающих основы медицинской генетики. В нём освещены вопросы истории генетики, в том числе формальной и медицинской генетики; молекулярных и цитогенетических основ наследственности, генетических и эпигенетических процессов, лежащих в основе патогенеза генетических болезней, их семиотики, а также различных методов исследования генома человека. Знание основ общей и медицинской генетики позволит понять молекулярные процессы, приводящие к патологическим изменениям в организме, приобрести знания по генетически обусловленным болезням, их диагностики, своевременно выбрать адекватные методы лечебной коррекции, направить семью на медико-генетическое консультирование с целью профилактики наследственной патологии.

Учебное пособие подготовлено в соответствии с требованиями Федерального государственного образовательного стандарта высшего профессионального образования по направлению подготовки 31.08.30 - «Генетика», 31.08.06 - «Лабораторная генетика», 31.08.20 - «Психиатрия», 31.08.19 - «Педиатрия» и предназначено для студентов, ординаторов и врачей, обучающихся в системе дополнительного профессионального образования, по специальностям: 31.08 .30 - «Генетика», 31.08 .06 - «Лабораторная генетика», 31.08.20 - «Психиатрия», 31.08.19 - «Педиатрия».

Печатается по решению Ученого Совета ФГБНУ «Научный Центр Психического Здоровья» «26 февраля» 2019 г, протокол № 2.

ISBN 978-5-91327-581-3

(С) Юров И.Ю., Ворсанова С.Г., Воинова В.Ю., Чурносов М.И., Юров Ю.Б., 2019

(с) ИД «Академия Естествознания»

(C) АНО «Академия Естествознания» 


\section{ОГЛАВ ЛЕНИЕ}

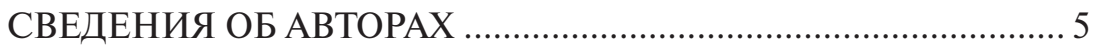

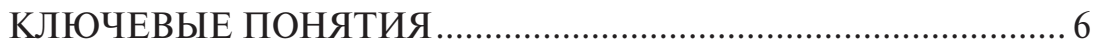

ГЛава 1. ИСТОРИЯ И ЗНАЧЕНИЕ ГЕНЕТИКИ В КОНТЕКСТЕ МЕДИКО-БИОЛОГИЧЕСКИХ ИССЛЕДОВАНИЙ ....... 7

1.1. Хромосомы человека...................................................... 9

1.2. ДНК как основа наследственности .................................. 15

1.3. Генетический объект - плодовая муха

(Drosofila melanogaster).................................................... 16

1.4. Краткая история медицинской генетики .......................... 16

1.4.1. Моногенные болезни ............................................ 18

1.4.2. Хромосомные болезни .............................................. 19

1.4.2.1. Микроделеционные

и микродупликационные синдромы ...... 24

1.4.3. Мультифакторные (многофакторные) болезни..... 37

1.4.4. Митохондриальные болезни ................................... 38

1.4.5. Вклад генетических болезней

в структуру заболеваемости ..................................... 39

Глава 2. МОЛЕКУЛЯРНЫЕ ОСНОВЫ

НАСЛЕДСТВЕННОСТИ ............................................ 40

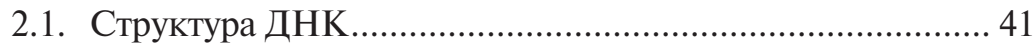

2.2. Синтез ДНК ................................................................... 42

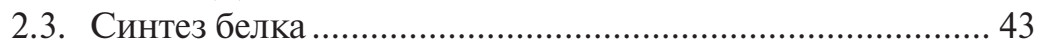

2.4. Вариации генома человека: генные мутации .................... 45

2.5. Эпигенетические процессы

и наследственные болезни ................................................ 48

Глава 3. ЦИТОГЕНЕТИЧЕСКИЕ ОСНОВЫ

НАСЛЕДСТВЕННОСТИ .............................................. 55

3.1. Геном человека и структурная организация хромосом..... 56

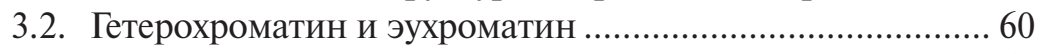

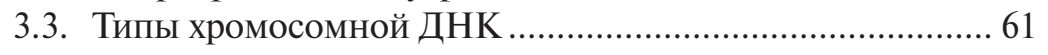




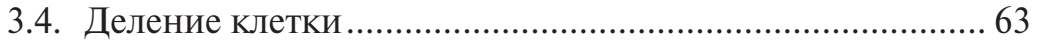

3.5. Вариации генома человека: хромосомные мутации ....... 67 ГЛава 4. СЕМИОТИКА ГЕНЕТИЧЕСКИ ОБУСЛОВЛЕННЫХ БОЛЕЗНЕЙ................................... 71

4.1. Особенности клинических проявлений наследственных болезний................................................. 71

4.2. Принципы клинической диагностики наследственных болезней ............................................. 74

4.3. Клинико-генеалогический анализ ..................................... 81

ГЛава 5. ФОРМАЛЬНАЯ ГЕНЕТИКА........................................... 83

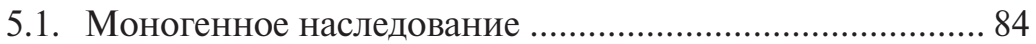

5.1.1. Аутосомно-доминантное наследование................. 84

5.1.2. Аутосомно-рецессивное наследование .................. 86

5.1.3. Наследование, сцепленное с полом...................... 87

5.2. Мультифакторное (многофакторное) наследование ...... 92

5.3. Митохондриальное наследование .................................... 92

ГЛава 6. ВРОЖДЁННЫЕ АНОМАЛИИ И СИНДРОМЫ ............ 95

6.1. Классификация врождённых аномалий .......................... 96

6.2. Генетические причины врождённых аномалий................ 99

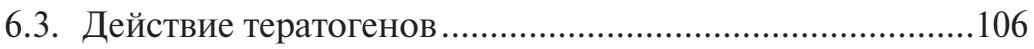

Глава 7. МЕТОДЫ ИЗУЧЕНИЯ ГЕНОМА ЧЕЛОВЕКА .............111

7.1. Молекулярно-генетические методы .................................112

7.2. Цитогенетические и молекулярно-цитогенетические

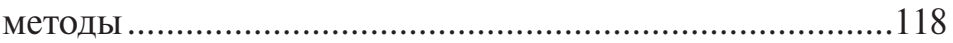

7.2.1. Цитогенетические методы ...................................119

7.2.2. Молекулярно-цитогенетические методы .............120

ГЛава 8. МЕДИКО-ГЕНЕТИЧЕСКОЕ КОНСУЛЬТИРОВАНИЕ (МГК) ...................................

РЕКОМЕНДУЕМАЯ ЛИТЕРАТУРА ...............................................144 РЕКОМЕНДУЕМЫЕ ЭЛЕКТРОННЫЕ РЕСУРСЫ ...................146 ПРИЛОЖЕНИЕ. Оценка основных антропометрических данных у детей 


\section{СВЕДЕНИЯ ОБ АВТОРАХ}

Юров И.Ю. - доктор биологических наук, профессор РАН, профессор кафедры медицинской генетики Академического образовательного центра фундаментальной и трансляционной медицины ФГБОУ ДПО РМАНПО Минздрава России, член-корр. РАЕ, заведующий лабораторией молекулярной генетики и цитогеномики мозга им. проф. Ю.Б. Юрова ФГБНУ «Научный центр психического здоровья», главный научный сотрудник ОСП НИКИ педиатрии им. академика Ю.Е. Вельтищева ФГБОУ ВО «РНИМУ им. Н.И. Пирогова» Минздрава России;

Ворсанова С.Г. - заслуженный деятель науки, доктор биологических наук, профессор, академик РАЕ, заведующая лабораторией молекулярной цитогенетики нервно-психических заболеваний ОСП НИКИ педиатрии им. академика Ю.Е. Вельтищева ФГБОУ ВО «РНИМУ им. Н.И. Пирогова» Минздрава России, главный научный сотрудник ФГБНУ «Научный центр психического здоровья»;

Воинова В.Ю. - доктор медицинских наук, главный научный сотрудник отдела клинической генетики ОСП НИКИ педиатрии им. академика Ю.Е. Вельтищева ФГБОУ ВО «РНИМУ им. Н.И. Пирогова» Минздрава России, ведущий научный сотрудник ФГБНУ «Научный центр психического здоровья»;

Чурносов М.И. - доктор медицинских наук, профессор, заведующий кафедрой медико-биологических дисциплин ФГАОУ ВО «Белгородский государственный национальный исследовательский университет», заслуженный работник высшей школы РФ;

Юров Ю.Б. - заслуженный деятель науки, доктор биологических наук, профессор, академик РАЕ, заведующий лабораторией цитогенетики и геномики психических заболеваний (до декабря 2017 года) ФГБНУ «Научный центр психического здоровья», главный научный сотрудник ОСП НИКИ педиатрии им. академика Ю.Е. Вельтищева ФГБОУ ВО «РНИМУ им. Н.И. Пирогова» Минздрава России (до декабря 2017 года). 


\section{КЛЮЧЕВЫЕ ПОНЯТИЯ}

Медицинская генетика - раздел генетики человека, изучающий роль генетических и эпигенетических факторов в возникновении наследственных заболеваний.

Клиническая генетика - прикладной раздел медицинской генетики, изучающий вопросы диагностики, профилактики, течения и лечения наследственных заболеваний.

Цитогенетика - наука, изучающая структуру и функцию хромосом.

Молекулярная генетика - раздел молекулярной биологии, изучающий основы наследственности и изменчивости путем исследования протекающих на молекулярном уровне процессов передачи, реализации и изменений генетической информации.

Молекулярная цитогенетика - наука, изучающая структуру и функцию хромосом (генома) с помощью молекулярных технологий. 


\section{Г Яава 1. ИСТОРИЯ И ЗНАЧЕНИЕ ГЕНЕТИКИ В КОНТЕКСТЕ МЕДИКО-БИОЛОГИЧЕСКИХ ИССДЕДОВАНИЙ}

История генетики представляет собой череду захватывающих открытий, благодаря которым общество получило возможность лечения и предотвращения многих тяжелейших заболеваний. Согласно современным представлениям, человек появился на Земле от 50 до 200 тысяч лет назад. Можно предполагать, что наследственность интересовала людей издавна. Так, в Халдее и Вавилоне около 6000 лет назад изучались родословные, прослеживающие передачу некоторых характеристик конской гривы. Ранние греческие философы Аристотель и Гиппократ считали, что признаки у человека передаются из поколения в поколение через семя, а матка женщины служит лишь «инкубатором». Они утверждали, что семя продуцирует всё тело человека, поэтому, например, отец с лысиной имеет лысого сына. Эти идеи превалировали вплоть до XVII-го столетия, когда датские ученые А. Ливенгук (A. Leeuwenhoek, 1632-1723 гг.) и Р. де Грааф (R. de Graaf, 1641-1673 гг.) открыли существование сперматозоидов (спермы) и яйцеклеток, объяснив тем самым передачу потомству как отцовских, так и материнских признаков.

Расцвет различных наук в XVIII-XIX столетиях вызвал рост интереса к наследственности. Пьер де Мопертуи (Pierre de Maupertuis, 1698-1759 гг.), французский натуралист, изучал наследование полидактилии (дополнительных пальцев) и альбинизма (недостатка пигментации) и показал, что эти аномалии поразному передаются в родословных. Джозеф Адамс (Joseph Adams, 1756-1818 гг.), английский врач, также анализировал различные механизмы наследования и опубликовал «Трактат о предполагаемых наследственных свойствах болезней», который явился предпосылкой к созданию медико-генетического консультирования. Джон Дальтон (John Dalton, 1766-1844 гг.) установил тот факт, что некоторые состояния, особенно цветовая слепота (дальтонизм) и гемофилия, наследуются сцеплено с полом. 
Настоящие представления о генетике сложились благодаря работам Грегора Менделя (Gregor Mendel, 1822-1884 гг.), который в 1865 году представил результаты экспериментов по скрещиванию гороха на заседании Общества Естествознания. Эти наблюдения были опубликованы, но оставались незамеченными. И лишь в 1900 году, через 16 лет после смерти Менделя, его эксперименты были воспроизведены. Сущность его работы была в открытии единиц наследственности - генов и того, каким образом они передаются в поколениях. Термин «ген» был впервые предложен датским ботаником У. Джохансеном (W. Johansen, 1857-1927 гг.), и был получен из введенного Г. де Врайсом (H. de Vries, 1848-1935 гг.) термина «панген», который, в свою очередь, был дериватом термина «Пангенезис», предложенного Чарльзом Дарвиным (C. Darwin, 1809-1882 гг.) в 1868 году. Определение «менделевский тип» сейчас применяют для обозначения наследования моногенных признаков и заболеваний, возникающих в результате изменений в одном гене. В 1906-1907 гг. английский учёный Уильям Бэтсон (William Bateson, 1861-1926 гг.) предложил для науки о наследственности и изменчивости название «генетика». Он был одним из иностранных членов Российской академии наук (1923 г.).

В своих экспериментах Мендель исследовал контрастирующие признаки садового гороха. Он заметил, что, если горох с таким наследственным признаком, как высокорослость, скрещивается с низким горохом, то в первом поколении - F1 - потомство будет высоким. Если же скрестить между собой гибриды первого поколения, это приведет к появлению высоких и низких растений в соотношении 3:1. Признаки, которые проявлялись в поколении F1, были названы доминантными, а те, которые проявлялись во втором поколении (F2), - рецессивными. Одним из обвинений в адрес Менделя было то, что он публиковал только те результаты, которые соответствовали его гипотезе. Согласно последней, пара контрастирующих признаков растения контролируется двумя факторами (генами), унаследованными по одному от каждого из родителей. До скрещивания растения имели по паре идентичных генов, т. е. были гомозиготны (представляли собой «чистые» линии). Гибриды первого поколения имели по одному гену высокорослости 
и низкорослости, т. е. были гетерозиготны. На основе проведенных опытов Менделем были сформулированы 3 основных закона:

1. Закон единообразия гибридов первого поколения отражает тот факт, что при скрещивании гомозигот (АА х аa) все потомство получается гетерозиготным и внешне идентичным (поколение F1, доминирующие признаки).

2. Закон сегрегащии (отделения, расщепления) утверждает то, что каждый отдельный признак индивидуума контролируется двумя генами, только один из которых может передаваться потомку.

3. Закон независимого наследования постулирует то, что различные пары генов передаются потомству независимо друг от друга. Существует ряд случаев, когда законы Менделя нарушаются, но, в целом, они остаются основополагающими.

К началу XX века было известно, что каждая клетка содержит ядро, внутри которого есть несколько нитевидных структур, названных хромосомами из-за своего сродства к определенным красителям (chroma - цвет, soma - тельце). В 1903 году Уолтер Саттон (Walter Sutton, 1877-1916 гг.) и Теодор Бовери (Theodor Boveri, 1862-1915 гг.) независимо друг от друга предположили, что хромосомы несут наследственные факторы или гены. Это предположение было поддержано наблюдениями за поведением хромосом при делении клетки, которое объясняло сегрегацию генов. Долгое время считалось, что нормальное число хромосом человека равно 48. Правильное их число (46) было установлено лишь в 1956 году Джо Тио (Joe Tjio, 1919-2001 гг.) и Альбертом Ливеном (Albert Levan, 1905-1998 гг.) через три года после открытия структуры ДНК. В течение нескольких лет выяснилось, что болезни человека могут быть связаны с потерей или приобретением хромосом или их участков. Затем стало известно, что некоторые структурные аномалии хромосом, такие как транслокации (обмен хромосомным материалом), могут передаваться и сегрегировать в семьях по законам Менделя.

\section{1. Хромосомы человека}

Хромосомный набор человека, определяемый как кариотип совокупность данных о структуре, размерах и количестве митотических хромосом, - установлен в начале 60 -х годов прошлого 
века. Ещё в 1888 году Г. Вальдеер (Н. Waldeyer, 1836-1921 гг.) ввёл термин «хромосома» для обозначения окрашенных нитевидных структур, видимых в ходе стадий деления клетки (митоза). Характерные особенности строения каждой хромосомы человека определяются, как известно, положением в ней центромеры важнейшей структуры, которая в делении клетки (митозе) соединяется с нитями веретена и определяет расхождение сестринских хроматид к противоположным полюсам клетки. Метафазная хромосома состоит из двух хроматид (сестринские хроматиды) и центромеры, при помощи которой они соединяются. В районе центромеры хромосома сужена, две её хроматиды сближены, и этот район в теле хромосомы образует первичную перетяжку. Центромера делит хромосому на два плеча (короткое и длинное). По положению центромеры и первичной перетяжки среди хромосом человека различают метацентрические хромосомы, у которых центромера расположена в середине хромосомы (медианно) и делит её на два равных по длине плеча; субметацентрические хромосомы, в которых центромера расположена субмедианно и делит хромосому на два плеча неравной длины; и акроцентрические хромосомы, у которых центромера расположена почти на конце хромосомы (терминально), отделяя от длинного очень короткое плечо. У некоторых хромосом на коротком плече двух хроматид на красящейся тонкой нити располагаются маленькие хроматические тельца - спутники. Участки на концах хромосомы называются теломерами. Структуры в виде точек прикрепления нитей митотического веретена к центромерам называются кинетохорами. Плечи некоторых хромосом содержат перетяжки, называемые «вторичными» (например, хромосомы 1, 9, 16). Диплоидный набор человека, состоящий из 46 хромосом, составлен из 23 пар гомологичных хромосом - гомологов (отцовского и материнского происхождения): 22 пары аутосом и плюс половые хромосомы (гоносомы) - XX у женщин или XY у мужчин. Гомологичные хромосомы, как правило, сходны между собой в размерах и строении, хотя могут встречаться некоторые отклонения от каждого показателя, и это носит название «гетероморфизм хромосом». Термин «кариотип» рекомендуется применять к систематизированному 
набору хромосом отдельной клетки человека. Существует также термин «идиограмма», который сохраняется для представления кариотипа в виде схемы, построенной на основании измерений хромосом большого числа клеток. Хромосомы пронумерованы серийно от 1 до 22 в соответствии с их длиной, а также с другими особенностями их строения, допускающими идентификацию. Половые хромосомы (гоносомы) не имеют номеров и обозначаются как Х и Ү. Следует отметить, что термины и «кариотип», и «идиограмма», получившие международное признание и распространение, принадлежат русским цитологам: «идиограмма» - С.Г. Навашину (1857-1930 гг.) в 1921 году и «кариотип» - Г.А. Левитскому (1878-1942 гг.) в 1924 году. В фазах деления - метафазах и прометафазах (см ниже) - хромосомы можно увидеть в световом микроскопе как дискретные удлинённые структуры длиной от 2 до 11 мкм. На рисунках 1 и 2 представлены мужской и женский кариотипы человека.

1

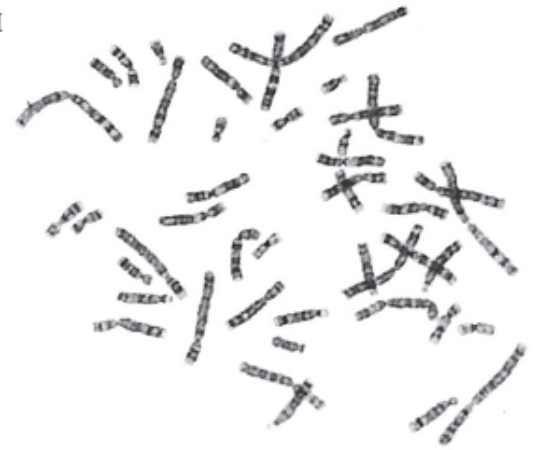

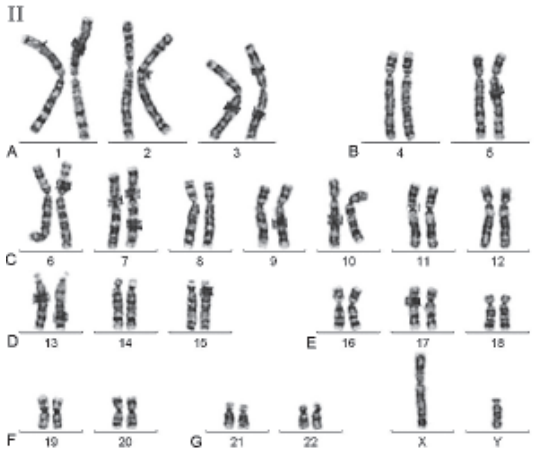

Рис. 1. Мужской кариотип:

I - метафазная пластинка;

II - классификация по группам и нумерация хромосом

Как указано выше, кариотип человека состоит из 46 хромосом, которые нумеруются от 1 до 22 (аутосомы) и делятся на 7 групп, - A, B, C, D, E, F, G и половые хромосомы (гоносомы) Х и Y (рис. 1 и 2).

K первой группе А относятся хромосомы 1, 2 и 3, которые хорошо отличаются друг от друга. Хромосома 1 (размер - 11 мкм) - 
метацентрическая, содержит вторичную перетяжку в околоцентромерном участке длинного плеча. Хромосома 2 (10,8 мкм) по размерам почти равна хромосоме 1 и является субметацентрической. Хромосома 3 (размер - 8,3 мкм) - практически метацентрическая.
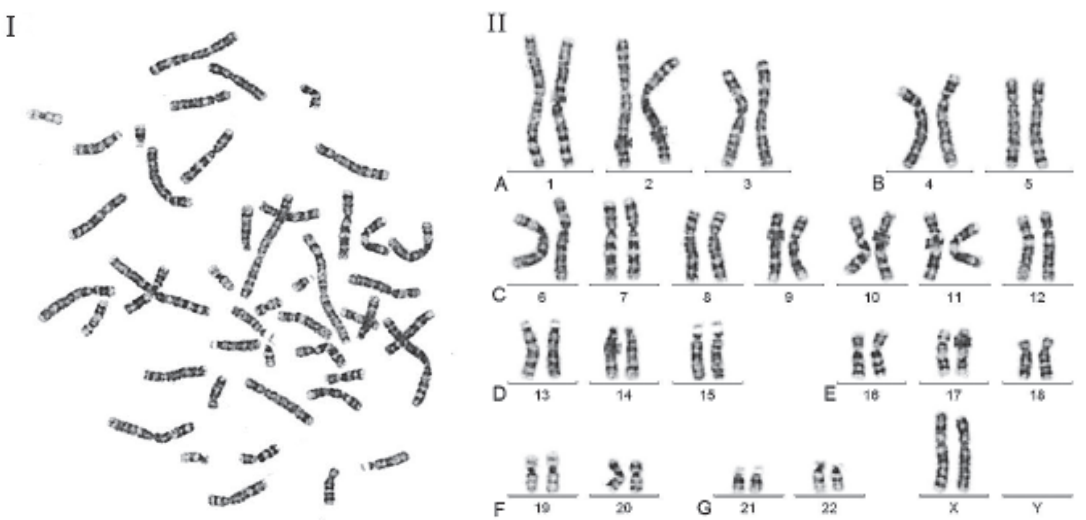

Рис. 2. Женский кариотип:

I - метафазная пластинка;

II - классификация по группам и нумерация хромосом

К группе В относятся хромосомы 4 и 5 (размер - 7,7 мкм каждая) - это крупные субметацентрические хромосомы, которые не отличаются друг от друга при рутинном окрашивании ни размером, ни положением центромер.

К группе С относятся хромосомы с 6 по 12 и Х. В основном, это субметацентрические хромосомы крупных и средних размеров. Наиболее крупные хромосомы из группы $\mathrm{C}-6,7$ и $\mathrm{X}$ (6,8-7,2 мкм). Хромосома Х является половой хромосомой (гоносомой). Хромосома 7 более метацентрична, чем хромосома 6. Хромосомы 8 и 9 - практически одинаковы по размеру (5,8 мкм). Хромосома 8 метацентричнее хромосомы 9, которая характеризуется регулярной вторичной перетяжкой в прицентромерном районе длинного плеча.

К группе D относятся хромосомы 13, 14 и 15 (4,2 мкм) - средних размеров акроцентрические хромосомы с почти терминальным 
расположением центромеры. Эти хромосомы между собой не различаются ни по размерам, ни морфологически после рутинного окрашивания. Короткое плечо всех трёх пар хромосом может формировать спутники (рис. 1, 2 и 5).

К группе Е относятся хромосомы 16, 17 и 18. Хромосома 16 (размер - 3,6 мкм) - сравнительно небольшая метацентрическая хромосома, содержащая вторичную перетяжку в длинном плече. Хромосома 17 (размер - 3,5 мкм) - сравнительно короткая субметацентрическая хромосома. Хромосома 18 (размер - 3,2 мкм) самая короткая субметацентрическая хромосома.

Группа F представлена хромосомами 19 и 20 (размеры 2,9 мкм). Это короткие метацентрические хромосомы, которые не отличаются между собой без дифференциального окрашивания по длине.

Хромосомы 21 и 22 (2,8 мкм) относятся к группе G. Это наиболее короткие акроцентрические хромосомы в кариотипе, которые обладают способностью формировать спутники на коротком плече (рис. 1, 2 и 5).

Хромосома Y (2,3 мкм) является маленькой акроцентрической хромосомой, сравнимой по размерам с хромосомами 21 и 22, но не имеющая спутников.

Важнейшая работа по созданию общей системы обозначения и классификации хромосом человека, представляемая в виде отдельной книги, проводилась регулярно из года в год, куда в последние десятилетия включались и результаты использования современных молекулярно-цитогенетических методов. Первые результаты работы учёных по номенклатуре и классификации хромосом человека были представлены в 1960 году в Денвере, в Университете штата Колорадо (США). Работа комиссии была проведена при поддержке американского онкологического общества. В состав комиссии входили известнейшие учёные: 14 учёных-цитологов и 3 учёных-генетика. Результаты были опубликованы в Денвере в том же 1960 году в ряде журналов в виде документа (книги), названного как «Стандартная система номенклатуры митотических хромосом человека». Впоследствии был создан комитет по номенклатуре хромосом человека. Комиссия 
и комитет периодически собирались для работы и, по мере развития цитогенетических, а в последние десятилетия и молекулярно-цитогенетических исследований, вносили поправки и дополнения в существующую классификацию. Работа комиссий проводилась регулярно в различных странах и городах. Комитет последовательно собирался в Париже, Чикаго, Мехико, ЛэйкПлэсиде, Эдинбурге, Стокгольме, где было решено разработать и опубликовать унифицированный вариант номенклатуры хромосом человека, включающий основные положения первых совещаний (Денвер, Лондон, Чикаго, Париж). Результаты работы комитета публиковались в различных издательствах. Этот важный документ получил название «Международная система номенклатуры хромосом человека» - «An International System for Human Cytogenetic Nomenclature» (ISCN). В дальнейшем поправки и дополнения в документе делались, учитывая новые разработанные технологии, включая молекулярно-цитогенетические, и докладывались на различных конференциях. Последний документ «ISCN 2016» - An International System for Human Cytogenetic Nomenclature» опубликован в 2016 году. Таким образом, в одном документе даётся полная номенклатура хромосом в норме и при хромосомных синдромах и аномалиях, исходя из цитогенетических и современных молекулярно-цитогенетических технологий (см рекомендуемую литературу).

Следует отметить, что хромосомные синдромы и аномалии связаны с хромосомными (геномныли) мутациями (аномалиями) в виде различных структурных перестроек хромосом или с изменением их числа (n). Численные изменения хромосом могут быть двух типов: полиплоидии - умножение хромосомного набора (3n, 4n и т. д.) или генома, кратное гаплоидному числу хромосом; анеуплоидии - увеличение или уменьшение числа хромосом, некратное гаплоидному. Структурные хромосомные (геномные) перестройки классифицируют по принципу линейной последовательности расположения генов: делеции (потеря хромосомных участков), дупликации (удвоение хромосомных участков), инверсии (перевертывание на $180^{\circ}$ относительно нормальной последовательности хромосомных участков), инсерции (вставки 
хромосомных участков) и транслокащи (изменение расположения хромосомных участков). Подробная информация по возможным аномалиям хромосом человека представлена в главе 3.5.

\section{2. ДНК как основа наследственности}

«Мы предлагаем вашему вниманию структуру ДНК, имеющую некоторые новые свойства, которые представляют значительный биологический интерес...». Так начиналась статья Джеймса Уотсона (James Watson, 1928 г. - настоящее время) и Френсиса Крика (Francis Crick, 1916-2004 гг.) в международном научном журнале «Nature» от 27 апреля 1953 года. В этой статье ученые предлагали модель двухцепочечной спирали ДНК, похожей на винтовую лестницу, «ступеньками» которой являются пары нуклеотидов «Аденин - Тимин» и «Гуанин - Цитозин». «Перилами» лестницы служат молекулы дезоксирибозы, а соединяются нуклеотиды в цепочку при помощи остатка фосфорной кислоты. Так, Джеймс Уотсон, Фрэнсис Крик и Морис Уилкинс (Maurice Wilkins, 19162004 гг.), получившие в 1962 году Нобелевскую премию, сделали одно из самых значительных открытий в биологии XX века: установили структуру молекулы ДНК - генетического материала клетки - носителя информации о наследственных признаках организма и обеспечивающего ее передачу из поколения в поколение. Ключевая роль ДНК для наследственности была открыта еще в 1940-х годах. До этого многие полагали, что наследственные признаки передаются белками. В 1944 году в институте Рокфеллера в Нью-Йорке, работая с пневмококками, Освальд Эйвери (Osvald Avery, 1877-1955 гг.), Маклин МакКарти (Macklyn McCarty, 1911-2005 гг.) и Колин МакЛеод (Colin McLeod, 1909-1972 гг.) определили ДНК как генетический материал. Связь между последовательностью оснований в ДНК и последовательностью аминокислот в белках (т.е. генетический код) была установлена с помощью биохимических методов в 1960-х годах. Таким образом, было постулировано то, что нарушение последовательности ДНК может приводить к изменению структуры белка. Подтверждения этого предположения были получены с развитием метода секвенирования ДНК (определения последовательности 
оснований в молекуле ДНК). Первой болезнью, охарактеризованной на молекулярном уровне, была серповидноклеточная анемия, при которой мутация гена гемоглобина ведёт к его повреждению и, как следствие, к заболеванию. Интересно, что еще в 1957 году это заболевание было идентифицировано определением структуры соответствующего белка.

\section{3. Генетический объект - пдодовая муха (Drosofila melanogaster)}

Стоит отметить заслуги одного небольшого насекомого, которое представляет собой ценный объект для генетических исследований. Плодовая мушка дрозофила обладает некоторыми особыми преимуществами перед другими лабораторными объектами: она легко разводится в лаборатории; быстро репродуцируется, давая 20-25 поколений за год; обладает рядом легко распознаваемых характеристик, таких как изогнутые крылья и желтое тело, которые наследуются согласно законам Менделя; имеет всего лишь четыре пары хромосом, сильно отличающихся друг от друга.

В силу своих уникальных свойств, дрозофила широко использовалась в ранних генетических экспериментах, и продолжает использоваться сегодня. С помощью дрозофилы были продемонстрированы расщепление и сегрегация признаков, их доминантность и рецессивность, сцепленное наследование генов; определена роль хромосом в процессе наследования; изучены организация хромосом и их «поведение» при делении клеток, процесс кроссинговера, химический мутагенез и др. У дрозофилы были идентифицированы многие гены, отвечающие за развитие различных признаков. Одним из достижений генетики стало секвенирование генома Drosofila melanogaster в 1999 году. Результаты многих из вышеперечисленных открытий использовались в генетике человека.

\section{4. Краткая история медицинской генетики}

Первые данные, связанные с медицинской генетикой, о моногенных заболеваниях были представлены Уильямом Бэйтсоном (William Bateson, 1861-1926 гг.) и Арчибальдом Гарродом 
(Archibald Garrod, 1857-1936 гг.), которые вместе предположили то, что алкаптонурия - рецессивно наследуемая болезнь. При этом заболевании моча становится темной при экспозиции на воздухе и при взаимодействии со щелочью из-за неспособности пациента метаболизировать гомогентизиновую кислоту. У больных отмечается склонность к артритам крупных суставов. Принимая во внимание вовлечение биохимических процессов при этом заболевании, Гаррод ввёл понятие врождённых ошибок метаболизма. В настоящее время идентифицированы сотни подобных болезней, описание которых дало начало такой науке, как биохимическая генетика.

В первые десятилетия XX века приобрело широкую известность такое научное направление, как евгеника. В ее основе лежала ранее сформулированная Френсисом Гальтоном (Francis Galton, 1822-1991 гг.) идея о возможности улучшения породы человека. Евгеника ставила своей целью искоренение наследственных заболеваний путем насильственной стерилизации больных и/или их родителей. В некоторых странах в первой половине $\mathrm{XX}$ века были приняты законы о принудительной стерилизации лиц, родивших детей с умственной отсталостью, шизофренией и рядом других заболеваний. Евгеника сыграла отрицательную роль в развитии генетики.

В России генетика успешно развивалась в 20-30 гг. XX века. Большой вклад в развитие генетики внёс Николай Константинович Кольцов (1872-1940 гг.), русский биолог, который с 1917 года возглавлял созданный им Институт экспериментальной биологии (ныне Институт биологии развития Российской Академии Наук). Н.К. Кольцову принадлежит «главная идея XX-го века в биологии» - идея матричного размножения биологических макромолекул («наследственных молекул»). В своем институте Н.К. Кольцов развернул исследования по медицинской генетике (первые работы по исследованию групп крови и т.д.), а также по таким вопросам генетики, как наследование цвета волос и глаз, изменчивость и наследственность сложных признаков у однояйцовых близнецов и т.д.

Одним из основоположников медицинской генетики в нашей стране стал Сергей Николаевич Давиденков (1880-1961 гг.), 
который был одновременно невропатологом и генетиком и внёс большой вклад в изучение генетики болезней нервной системы. Кроме того, он сформулировал понятие генетической гетерогенности болезней нервной системы, поставил вопрос о создании каталога генов человека, а также способствовал созданию медико-генетического консультирования.

С 1930 г. по 1937 г. в медико-биологическом, переименованном затем в медико-генетический институт, под руководством профессора С.Г. Левита (1894-1937 гг.) проводились близнецовые и цитогенетические исследования. Однако в 1937 году институт был закрыт, а его директор подвергнут репрессиям. До 60-х годов развитие генетики в нашей стране было остановлено. В ее возрождении в 60-е годы приняли активное участие С.Н. Давиденков, Н.В. Тимофеев-Ресовский, В.П. Эфроимсон, А.А. Прокофьева-Бельговская, С.Н. Ардашников, Е.Ф. Давиденкова и др.

В течение последних десятилетий двадцатого столетия стало ясно, что наследственные факторы лежат в основе многих заболеваний. Традиционно наследственные болезни рассматривают под названиями «моногенные, хромосомные, мультифакторные или многофакторные (ошибочно называемые ранее мультифакториальными) и митохондриальные», которые будут представлены ниже.

\subsection{1. Моногенные болезни}

Одной из обширных групп наследственно детерминированных заболеваний являются генные болезни. Этиологическим фактором моногенных болезней служат мутации в отдельных генах. Частота моногенных заболеваний среди новорожденных оценивается в $2 \%$. Ещё английский врач А. Гэррод (А. Garrod, 1857-1936 гг.) в начале прошлого века (1908 г.) предположил, что кроме алкаптонурии, выявленной в 1902 году, аутосомно-рецессивно наследуются альбинизм и гомоцистинурия. Вскоре последовали другие примеры (фенилкетонурия, тирозинемия, кретинизм). К 1966 году почти 1500 моногенных болезней и признаков были описаны, что побудило американского учёного Виктора МакКьюсика (Victor McKusick, 1921-2008 гг.) к публикации каталога всех известных к тому времени моногенных состояний. К 1998 году, 
когда было опубликовано двенадцатое издание каталога, в нем содержалось свыше 8500 наименований. Экспоненциальный рост каталога привел к тому, что сейчас он не публикуется в печатном виде, а доступен через сеть Internet как Online Mendelian Inheritance in Man (OMIM) (см рекомендуемую литературу). Интересно отметить, что в настоящее время каталог содержит около 25000 статей о моногенных болезнях и признаках, среди них аутосомные, сцепленные с хромосомами X и Y, а также о митохондриальных болезнях. Каталог содержит на сентябрь 2018 года 24781 публикацию (табл. 1).

Таблица 1

Статистика каталога ОМІМ, сентябрь 2018 года

\begin{tabular}{|c|c|c|c|c|c|}
\hline $\begin{array}{c}\text { Категории } \\
\text { болезней } \\
\text { и признаков }\end{array}$ & $\begin{array}{c}\text { Ауто- } \\
\text { сомные }\end{array}$ & $\begin{array}{c}\text { Сцепленные } \\
\text { с хромосо- } \\
\text { мой X }\end{array}$ & $\begin{array}{c}\text { Сцепленные } \\
\text { с хромосо- } \\
\text { мой Y }\end{array}$ & $\begin{array}{c}\text { Митохон- } \\
\text { дриаль- } \\
\text { ные }\end{array}$ & Всего \\
\hline $\begin{array}{l}\text { Количество } \\
\text { заболеваний } \\
\text { и признаков }\end{array}$ & 23364 & 1289 & 60 & 68 & 24781 \\
\hline
\end{tabular}

\subsection{2. Хромосомные болезни}

Совершенствование техники микроскопии привело к открытию в 1959 году того факта, что дополнительная хромосома 21 в кариотипе (трисомия хромосомы 21) ведет к развитию синдрома Дауна. Вскоре последовали другие подобные открытия. Так в 1960 году был описан синдром Патау (трисомия хромосомы 13), основными признаками которого являются расщелина верхней губы и нёба, поражения ЦНС, при этом наиболее постоянна аринэнцефалия, часто выявляются аплазия и гипоплазия червя мозжечка, голопрозэнцефалия и связанные с ней циклопия, этмоцефалия, цебоцефалия. В том же 1960 году Джон Эдвардс (John Edwards, 1928-2007 гг.) с сотрудниками при цитогенетическом исследовании клеток больных с множественными врождёнными пороками развития обнаружили добавочную (лишнюю) хромосому 
в кариотипе из группы Е. В дальнейшем эту хромосому определили как 18, и эту трисомию стали называть синдромом Эдвардса. Цитогенетика - наука, изучающая структуру и функции хромосом, на несколько десятилетий стала ведущим направлением в генетике человека. Появление в начале 70-х годов методов дифференциального окрашивания хромосом по длине позволило идентифицировать индивидуальные хромосомы и установить то, что потеря или приобретение сегмента хромосомы может быть причиной нарушения развития организма.

В настоящее время развивается молекулярная ицтогенетика, которая имеет дополнительный методический арсенал для идентификации хромосомных аномалий, включая микроперестройки. Методы молекулярной цитогенетики основаны на специфических биохимических свойствах молекул нуклеиновых кислот, предоставляя возможность детекции последовательностей ДНК и РНК в каждой клетке. Впервые детекция нуклеиновых кислот с использованием радиоактивной метки in situ (непосредственно на препарате) была описана в 1969 году американскими учеными М.Л. Пардю (M.L. Pardue, 1933 г. - настоящее время) и Д. Голлом (D. Gall, 1928 г. - настоящее время). Однако понадобилось не одно десятилетие для того, чтобы молекулярно-цитогенетические методы, а именно IISH (isotopic in situ hybridization - изотопная in situ гибридизация), нашли свое применение для лабораторной диагностики наследственных заболеваний. Необходимо отметить, что их внедрение в медицинскую практику является заслугой таких отечественных учёных - молекулярных цитогенетиков, как С.Г. Ворсанова, И.В. Соловьев и Ю.Б. Юров. Впоследствии эти методы были модифицированы с целью определения специфических последовательностей молекул ДНК на хромосомах человека с использованием нерадиоактивных ДНК зондов и, таким образом, было положено начало молекулярно-цитогенетическим исследованиям с использованием флюоресценции (FISH). C cередины 80-х годов они динамично развиваются и начинают использоваться в диагностике хромосомных синдромов и аномалий. В частности, отечественными исследователями было показано, что многие из них являются необходимыми дополнительными 
методами для уточнения цитогенетического диагноза (см рекомендуемую литературу).

Далее были разработаны технологии геномной гибридизации: высокоразрешающей метафазной геномной гибридизации и серийной сравнительной геномной гибридизации (HR CGH и arrayCGH). Исследование методом HR CGH проводилось на метафазных пластинках с использованием смеси меченых одним флюорохромом геномной ДНК пациента и другим флюорохромом ДНК донора (при исследовании численных хромосомных аномалий) или геномной ДНК какой-то конкретной хромосомы донора (при исследовании структурных хромосомных аномалий). Затем с помощью цифрового анализа производилась сравнительная оценка интенсивности суперпозиции сигналов двух разных флюорохромов, в результате чего становилось возможным определение приобретения или потери последовательностей ДНК у пациента в строго определенных участках хромосом. При отсутствии количественных изменений в кариотипе исследуемого образца наблюдается соотношение 1:1 интенсивности свечения двух флюорохромов. В случае дупликации интенсивность сигнала соответствующего флюорохрома будет увеличиваться, а в случае потери генетического материала, наоборот, уменьшаться. Метод высокоразрешающей метафазной CGH позволяет идентифицировать несбалансированные хромосомные перестройки с использованием только геномной ДНК. Среди ограничений метода HR CGH необходимо отметить невозможность выявления мозаицизма и сбалансированных перестроек. Разрешение метода может составить 1-2 млн пар нуклеотидов (пн), позволяя использовать высокоразрешающую CGH для диагностики в медико-генетической практике.

Разработка протоколов модификации CGH технологии была направлена на создание высокоразрешающих методов идентификации хромосомных микроаберраций (микроделеций и микродупликаций). В результате этого были созданы методы arrayCGH анализа, а также ВАC (ВАC - искусственные бактериальные хромосомы) и олигонуклеотидная CGH. Метод серийной сравнительной геномной гибридизации (молекулярного кариотипирования) или arrayCGH - это анализ, который основан 
не на гибридизации тотальной геномной ДНК донора и пациента на метафазных хромосомах, как HR CGH, а на замене клеточной суспензии хромосом донора на специфические последовательности ДНК, соответствующие определенным участкам хромосом. Для их иммобилизации используют наночип, на который наносится от нескольких тысяч до нескольких миллионов проб. Затем меченые ДНК гибридизуют на данном чипе. СGH проводится несколькими сериями с использованием цифровых систем детекции суперпозиции сигналов. Модификациями arrayCGH анализа являются ВАС и олигонуклеотидная CGH. Эти технологии имеют большую разрешающую способность за счет применения ВАС ДНК размером от 100000 до 350000 пн или олигонуклеотидных последовательностей ДНК размером от 25-100 пн и более. Данные методы используются для идентификации хромосомных микроаберраций, а также генных мутаций, затрагивающих последовательности ДНК, размер которых может быть больше 50 пн. Существует 4 основных разновидностей наночипов:

1) чип с пробами на определенные участки генома;

2) чип, сканирующий геном с разрешением 1 млн пн (расстояние между локализацией каждой пробы составляет примерно 1 млн пн);

3) чип, сканирующий геном «перекрывающими» друг друга ВАС пробами, разрешением около 100 тысяч пн;

4) чип, сканирующий геном с использованием олигонуклеотидных/SNPs проб, разрешением около 1 тысячи пн.

Кроме идентификации потери или приобретения последовательностей ДНК модифицированные протоколы arrayCGH могут быть использованы для высокоразрешающих эпигенетических исследований генома (анализ экспрессии последовательностей ДНК/РНК или метилирования ДНК). Они также применимы для анализа последствий вариаций гетерохроматиновых участков ДНК в плане изменения свойств генов, локализованных в непосредственной близости к этим хромосомным районам. При исследовании геномных вариаций вышеперечисленными технологиями обнаружено, что, помимо ранее описанных хромосомных аномалий, более 5 \% последовательностей ДНК генома (включая 
множество генов) участвуют в субмикроскопических хромосомных перестройках, фенотипические проявления которых имеют неочевидные последствия. Для определения степени патогенности выявленной хромосомной перестройки используются следующие приемы:

1) обследование родственников пациента с помощью метода arrayCGH (в первую очередь родителей);

2) создание доступных баз исследований разного разрешения с помощью метода arrayCGH.

Последнее имеет значение для диагностической практики, особенно применительно для arrayCGH, позволяющей проводить сравнительный анализ результатов отдельного индивидуума с данными предыдущих исследований.

Исследования методом arrayCGH были признаны одними из наиболее эффективных среди молекулярно-цитогенетических технологий. Разрешение этого метода сравнимо с методами, основанными на FISH, а во многих случаях arrayCGH заменила их (например, исследование субтеломерных аномалий, микроделеционных/микродупликационных синдромов, на которых мы остановимся отдельно в следующей главе - 1.4.2.1). По последним данным, такой анализ выявляет субтеломерные перестройки в 5-25\% случаев умственной отсталости. Это практически в 2 раза больше по сравнению с данными, полученными при более ранних исследованиях. Примечательно то, что, по некоторым данным, вклад субтеломерных делеций, идентификация которых ранее была затруднена вследствие недостаточно высокого уровня разрешения стандартных методов, сравним с вкладом интерстициальных хромосомных перестроек. Более того, применение метода arrayCGH позволило выделить целый ряд достаточно частых и ранее неизвестных микроделеционных синдромов (например, микроделеции в участках 16p11.2p12.2 и 17q21.31). Помимо этого, вариации генома в виде делеций и дупликаций, определённых с помощью метода высокоразрешающей arrayCGH, достаточно часто обнаруживаются у детей, страдающих аутизмом (до $10 \%$ случаев). Среди индивидуумов с врождёнными пороками сердца около $30 \%$ имеют хромосомные микроперестройки, более 
половины из которых достоверно связана с данной патологией. Следует особо отметить, что многие микроперестройки генома при врождённых пороках сердца можно обнаружить только с использованием arrayCGH. Имеются также данные о том, что эта технология позволяет не только уточнить аномалии хромосом в клетках опухолей и при гематологических заболеваниях, но и определять хромосомные участки для последующего картирования онкогенов, а в некоторых случаях непосредственно их выявлять. Эти возможности метода arrayCGH являются исключительно значимыми в пренатальной, доклинической и постнатальной диагностике, а также в прогнозировании, мониторинге и терапевтическом вмешательстве при всех перечисленных заболеваниях, которые в совокупности являются основной причиной инвалидизации как детей, так и лиц в старшем возрасте.

Таким образом, можно с уверенностью утверждать, что методы молекулярной цитогенетики (особенно следует отметить arrayCGH) являются необходимыми для корректного и эффективного изучения широкого спектра заболеваний, включая микроделеционные и микродупликационные синдромы, и отсутствие данных технологий в арсенале соответствующих научных и научно-практических учреждений заметно снижает их исследовательский и диагностический потенциал.

\subsubsection{1. Микроделеционные и микродупликационные синдромы}

Ранее, при исследовании кариотипа классическими цитогенетическими методами, считалось, что структурные аномалии хромосом (инсерции, инверсии, делеции, дупликации, транслокации) встречаются значительно реже, чем численные. Выявление структурных аномалий хромосом зависит от их размера, локализации, типа перестройки (регулярная или мозаичная), а также метода, используемого для исследования. При этом разрешающая способность классических цитогенетических методов составляет от 5-7 млн пн. С внедрением современных молекулярно-цитогенетических технологий исследования хромосом (генома) стали возможны с разрешающей способностью от 1000 пн и меньше, что позволяет обнаружить субмикроскопические перестройки 
и уточнить координаты геномных нарушений, в том числе микроделеций и микродупликаций, и число обнаруженных структурных перестроек, значительно возросло. Это, в свою очередь, позволяет получать информацию о генах, находящихся в исследуемых участках, и в дальнейшем проводить биоинформатический анализ с целью определения генов-кандидатов патологических фенотипических проявлений у детей.

Данные аномалии часто выявляются при анализе генома детей с недифференцированными формами умственной отсталости, микроаномалиями развития (MAР) и врождёнными пороками развития (ВПР). Известно, что структурные аномалии хромосом ассоциированы с определёнными фенотипическими проявлениями, в том числе, как и с наиболее частыми микроделеционными/ микродупликационными синдромами, так и с редкими микроаномалиями. Несмотря на это, даже при наиболее часто встречающихся микроделеционных/микродупликационных синдромах, затрагивающих области, в которых локализованы более 100 генов, вклад отдельных генов в формирование патологических фенотипических проявлений ещё предстоит изучать. Наиболее часто встречающиеся микроделеционные/микродупликационные синдромы и аномалии представлены в таблице 2. У многих синдромов, описанных с внедрением современных молекулярноцитогенетических технологий, частота не известна. Ниже даётся описание отдельных микроделеционных/микродупликационных синдромов и аномалий.

\section{Синдром микроделеции 1 p36}

При данном синдроме наблюдаются задержка моторного развития, расстройства аутистического спектра; некоторые исследователи отмечают, что $25 \%$ пациентов могут ходить самостоятельно, широкой походкой, примерно к 2-7 годам. Экспрессивная речь отсутствует в $75 \%$ случаев, понимание обращенной речи ограничено определенными ситуациями. Стремление к коммуникации в ранние периоды развития проявляется слабо, но улучшается со временем при расширении используемых жестов. Многие исследователи выявляют следующие клинические 
признаки: резкие перемены настроения, самоповреждающее поведение, стереотипии и МАР: прямые брови, микроцефалия, широкая переносица, низко расположенные аномальной формы ушные раковины, клинодактилия, небольшие ступни, а также отмечают пороки сердечно-сосудистой системы (ССС).

\section{Микроделеции 1q41q42}

При микроделеции 1q41q42 наблюдаются умеренная умственная отсталость, аутизм, судороги, микроцефалия, косолапость, МАР: гипотелоризм глазных щелей, вывернутые вперёд ноздри.

\section{Синдром микроделеции 2q37}

Описано более 100 клинических случаев с микроделецией участка 2q37. У этих индивидуумов обычно отмечается лёгкая или умеренная задержка психического развития, у $30 \%$ пациентов имеются черты аутизма. Дети обычно невысокого роста с гипермобильными суставами, сколиозом, синдактилией кистей и/или стоп. Пороки сердца встречаются у $35 \%$, нередко выявляются пороки почек. К характерным лицевым аномалиям при синдроме микроделеция 2q37 относят следующие: брахицефалия, круглое широкое лицо, редкие волосы на голове, широкие лоб и нос с расщеплением кончика, глубоко посаженные глаза, редкие высокие арочные брови, готическое нёбо; отмечают также укороченные фаланги пальцев рук и ног, экзему.

\section{Микроделеции 3q29}

При данной микроделеции наблюдается умственная отсталость средней тяжести, отмечаются аутистические черты, МАР: микроцефалия, длинное узкое лицо, большие ушные раковины, аномально сформированная спинка носа, а также атаксия, пороки сердца и почек. Нередко отмечают аутистические проявления.

\section{Микродупликации 4p16.3}

При данной микродупликации наблюдается умственная отсталость средней тяжести, встречаются аутистические проявления, задержка роста, задержки психомоторного (ЗПМР) 
и психоречевого развития (ЗПРР), микроцефалия, лицевые аномалии: высокий лоб, низко расположенные ушные раковины, короткая шея, аномалии глазных щелей, а также гипотония с мышечной гипотрофией, пороки ССС.

\section{Синдром Вольфа-Хиршхорна (делеция в участке 4p16)}

При данной микроделеции наблюдаются умственная отсталость различной степени тяжести, задержка роста, ЗПМР и ЗПРР, микроцефалия, лицевые микроаномалии: высокий лоб, эпикант, маленький рот с опущенными углами, клювовидный нос с выступающим надпереносьем, микрогения, низко расположенные деформированные ушные раковины с преарикулярными складками, короткая шея, а также пороки ССС, почек, желудочно-кишечного тракта, гипоспадия, гипотония с мышечной гипотрофией, судороги. Иногда встречаются пороки мозга в виде агенезии или гипоплазии мозолистого тела, гипоплазии мозжечка. Характерным признаком синдрома является воронкообразное углубление в области крестца (sinus sacralis). Частота этого синдрома в популяции 1:90000 - 100000 по данным публикаций различных авторов. Встречаются аутистические расстройства.

\section{Синдром «крика кошки» («cri du chat», делеция в участке 5p15.2)}

Наибольшее отставание в развитии при этом синдроме наблюдается при навыках, которые требуют мобильности, ловкости и вербальной коммуникации. По сравнению с мелкой моторикой, крупная моторика рук относительно сохранна и дети способны совершать «машущие» движения рукой или поймать мяч. Отсутствие речи компенсируется у 2/3 детей при помощи невербальных методов коммуникации, примерно $50 \%$ детей способны использовать язык жестов для сообщения основных потребностей. Основным диагностическим признаком синдрома является «крик кошки», связанный с изменением гортани (сужение, мягкость хрящей, отечность или складчатость слизистой, уменьшение надгортанника). Наблюдаются также следующие клинические признаки: умственная отсталость, микроцефалия, низко расположенные деформированные ушные раковины, микрогения, 
гипертелоризм и антимонголоидный разрез глазных щелей, эпикант, косоглазие, гипотония мышц, пороки ССС, иногда выявляют аринэнцефалию, гипоплазию мозжечка, микрогирию больших полушарий, пороки развития почек и желудочно-кишечного тракта. Частота синдрома в популяции 1:45000.

Синдромы Вольфа-Хиршхорна и «крика кошки» относятся к делеционным синдромам, но довольно часто геномные микроаномалии затрагивают только критические сегменты хромосом (4p16 и 5p15, соответственно), и тогда можно их отнести к микроделеционным синдромам.

\section{Микродупликации 7p22.1}

При данной микродупликации наблюдаются умственная отсталость различной степени тяжести, аутизм, черепно-лицевые аномалии: макроцефалия, гипертелоризм глазных щелей, аномалии ушных раковин.

\section{Синдром Вильямса (делеция в участке 7q11.23)}

Основными проявлениями синдрома являются хрипловатый голос, отсутствие чувства дистанции при общении. У пациентов с синдромом Вильямса наблюдается слабая зрительно-моторная интеграция, в результате чего вместо целостной картинки они видят ее отдельные составные части. Кроме того, у больных выявлены макроцефалия, макрокрания, мышечная гипотония, МАР: широкий лоб, глубоко посаженные глазные щели, широкая короткая переносица, оттопыренные ушные раковины, колобома, аномалии зубов; потеря слуха, тревожность, дефицит внимания с гиперактивностью (СДВГ), пороки ССС. Многие дети с этим синдромом могут играть на музыкальных инструментах, общительны, не имеют задержки в речевом развитии. Частота 1:10000 20000 по данным публикаций различных авторов.

\section{Микроделеции 11q13}

При данной микроделеции наблюдаются ЗПРР, расстройства аутистического спектра, МАР: синофриз, широкий нос, ретрогнатия, широкие пальцы с короткими дистальными фалангами. 


\section{Синдром микродупликации 15q11q13}

Следует отметить, что микродупликацию 15q11q13 можно отнести к часто встречающимся цитогенетическим аномалиям при аутизме. По данным литературы, указанная микроперестройка встречается примерно у $1 \%$ детей с аутизмом, и она индексирована в базе данных OMIM (Online Mendelian Inheritance in Man) (ОМІМ:608636) как генетически обусловленное состояние. Имеются исследования, направленные на приоритизацию генов-кандидатов психических нарушений у пациентов с перестройками в этом участке, включая и микродупликацию.

\section{Синдром Ангельмана (делеция или унипарентальная дисомия} в участке 15q11.2q13 материнского происхождения)

Нарушения в данном участке связаны с таким генетическим заболеванием, как синдром Ангельмана при нарушении в хромосоме материнского происхождения. При перестройке материнского происхождения у детей часто наблюдаются эпилепсия, атаксия, умственная отсталость и характерные лицевые микроаномалии. Основной значимой характеристикой синдрома Ангельмана является чрезмерно положительное настроение с постоянной улыбкой и смехом у ребёнка. Выявляются фокальные стереотипии, однако не наблюдаются специфичные, часто повторяющиеся стереотипные движения. Дети заинтересованы в социальных взаимодействиях, многие пациенты стремятся к коммуникации, несмотря на выраженные нарушения речи. Пациенты испытывают трудности во взаимодействии по причине слабого понимания социальных и эмоциональных сигналов. Психические нарушения зависят от происхождения перестройки, а именно, от того, является ли делетированный участок материнским или отцовским. Это позволяет говорить о том, что эпигенетический феномен геномного импринтинга играет значимую роль в этиологии и патогенезе психических нарушений.

\section{Синдром Прадера-Вилли (делеция или унипарентальная} дисомия в участке 15q11.2q13 отцовского происхождения)

Нарушения поведения при данном синдроме проявляются в резких перепадах настроения, упорстве, соответствующем 
поведении, обсессивно-компульсивных характеристиках, а также сложностью в отвлечении от ежедневно повторяемых рутинных событий. Синдром Прадера-Вилли ассоциирован с повышенным риском психических нарушений. Пациенты с синдром ПрадераВилли при отсутствии отцовской копии указанного участка хромосомы 15 (унипарентальная дисомия) подвержены различным психическим расстройствам.

\section{Микроделеции 15q24}

При данной микроделеции наблюдаются умственная отсталость, низкорослость, микроцефалия, пониженный мышечный тонус (гипотония), скелетные аномалии, гипоспадия.

\section{Синдром микроделеции 16p11.2}

Перестройки в участке 16p11.2, по данным литературы, ассоциированы с аутизмом и лёгкой формой умственной отсталости. При исследовании детей с расстройствами аутистического спектра микроделеция участка 16p11.2 выявляется в 0,4-1,2\% случаев. Чаще обнаруживают эту микроделецию de novo; тем не менее, микроделеция также может передаваться от родителей к ребёнку. Микроделеции участка $16 \mathrm{p} 11.2$ встречаются чаще при аутизме по сравнению с микродупликациями этого же участка. У пациентов с микроделецией в данном участке отмечают более тяжёлые фенотипические проявления по сравнению с микродупликацией. Выявляются следующие врождённые проявления: задержка речевого развития (3РP), отставание в физическом развитии, двигательные нарушения, эпилепсия, пороки сердца, ожирение. Среди МАР отмечают низко расположенные ушные раковины и частично перепончатые пальцы.

\section{Синдром Смит-Маженис (делеция в участке 17p11.2)}

Для микроделеции участка 17p11.2 характерны различные фенотипические проявления. Эти признаки были объединены в синдром Смит-Маженис, индексированным в ОМIM (182290). Для синдрома характерны черепно-лицевые 
аномалии (широкое/плоское лицо, широкая переносица, выпуклый лоб, сросшиеся брови, низко расположенные ушные раковины), широкие короткие кисти, плоскостопие, брахидактилия, а также нарушения развития и поведения. Черты аутизма присутствуют более чем у $50 \%$ детей с данным синдромом. У 80 \% пациентов проявляется самоповреждающее поведение (аутоагрессия), включая онихотилломанию, кусание запястий, качание головой, а также повышенную толерантность к боли, нарушение сна. Навыки импрессивной речи, как правило, выше, чем экспрессивной. Хриплый голос может являться диагностическим маркером синдрома. Использование языка жестов значительно способствует улучшению коммуникативных способностей ребенка. Выявляют умственную отсталость от умеренной до тяжёлой степени.

Следует сказать и про микродупликацию в этом участке, которая ассоциирована с синдромом Потоцки-Лупски, индексированным в ОМІМ (610883). Заболевание проявляется гипотонией мышц, врождёнными пороками развития, лицевыми аномалиями, пороками ССС, низким ростом и различными нервными и психическими нарушениями. По данным исследований, аутизм встречается у этих детей в $65 \%$ случаев.

\section{Синдром микроделеции 22q11.2}

Синдром микроделеции участка 22q11.2 ассоциируется с аутизмом, велокардиофациальным синдромом и синдромом ДиДжорджи. Частота его составляет 1:4000 новорождённых. У детей с такой перестройкой выявляют нарушение психического и моторного развития, отмечают медленный рост и гипотонию. К менее распространённым нарушениям при нём можно отнести аномалии ССС, расщелину нёба, лицевые МАР, нарушение иммунитета. Аутистические проявления наблюдаются также у 15-25\% пациентов с микродупликацией в данном участке. 


\section{Синдром микроделеции 22q13.3}

Синдром микроделеции 22q13.3 известен также как синдром Фелан-МакДермид. Он с одинаковой частотой встречается у лиц мужского и женского пола. К характерным признакам данного синдрома можно отнести неонатальную гипотонию, микроаномалии развития, задержку или полное отсутствие речи, аутизм и эпилепсию. К основным фенотипическим проявлениям данного синдрома относятся следующие: большие ушные раковины, диспластичные ногти, широкий лоб, острый подбородок. При исследовании нескольких групп детей с микроделецией в участке 22q13.3 аутистические черты были выявлены у $85 \%$ пациентов.

Основные характерные особенности, свойственные известным микроделеционным и микродупликационным синдромам, представлены в таблице 2.

Таблица 2

Характерные особенности некоторых часто встречающихся микроделеционных* и микродупликационных* синдромов и аномалий

\begin{tabular}{|c|c|c|c|c|c|}
\hline $\begin{array}{c}\text { Син- } \\
\text { дромы } \\
\text { и анома- } \\
\text { лии }\end{array}$ & $\begin{array}{c}\text { Основ- } \\
\text { ная гене- } \\
\text { тическая } \\
\text { причина }\end{array}$ & Частота & $\begin{array}{c}\text { Умствен- } \\
\text { ная от- } \\
\text { сталость }\end{array}$ & Аутизм & $\begin{array}{l}\text { Характерные феноти- } \\
\text { пические проявления }\end{array}$ \\
\hline 1 & 2 & 3 & 4 & 5 & 6 \\
\hline $\begin{array}{l}\text { Делеции } \\
1 \text { p36 }\end{array}$ & $\begin{array}{l}\text { Делеция } \\
1 \text { p36 }\end{array}$ & $\begin{array}{l}1: 4000- \\
1: 10000\end{array}$ & $\begin{array}{l}\text { Тяжёлая } \\
\text { степень } \\
\text { умствен- } \\
\text { ной от- } \\
\text { сталости }\end{array}$ & $\begin{array}{l}\text { Неко- } \\
\text { торые } \\
\text { прояв- } \\
\text { ления } \\
\text { аутизма }\end{array}$ & $\begin{array}{l}\text { Резкие перемены на- } \\
\text { строения, самоповреж- } \\
\text { даюеее поведение, } \\
\text { стереотипии, МАР: } \\
\text { прямые брови, микро- } \\
\text { цефалия, широкая } \\
\text { переносица, низко } \\
\text { расположенные ано- } \\
\text { мальной формы ушные } \\
\text { раковины, клино- } \\
\text { дактилия, небольшие } \\
\text { ступни, пороки ССС. }\end{array}$ \\
\hline
\end{tabular}


Продолжение табл. 2

\begin{tabular}{|c|c|c|c|c|c|}
\hline 1 & 2 & 3 & 4 & 5 & 6 \\
\hline $\begin{array}{l}\text { Делеция } \\
\text { 1q41q42 }\end{array}$ & $\begin{array}{l}\text { Делеция } \\
\text { 1q41q42 }\end{array}$ & - & $\begin{array}{l}\text { Умерен- } \\
\text { ная ум- } \\
\text { ственная } \\
\text { отста- } \\
\text { лость }\end{array}$ & Аутизм & $\begin{array}{l}\text { МАР: гипотелоризм } \\
\text { глазных щелей, вы- } \\
\text { вернутые вперёд } \\
\text { ноздри, микроце- } \\
\text { фалия, косолапость, } \\
\text { судороги. }\end{array}$ \\
\hline $\begin{array}{l}\text { Делеции } \\
\text { 2q37 }\end{array}$ & $\begin{array}{l}\text { Делеция } \\
2 \text { q37 }\end{array}$ & - & $\begin{array}{l}\text { Умствен- } \\
\text { ная от- } \\
\text { сталость } \\
\text { средней } \\
\text { степени } \\
\text { тяжести }\end{array}$ & Аутизм & $\begin{array}{l}\text { МАР: брахицефалия, } \\
\text { круглое, широкое } \\
\text { лицо, высокие ароч- } \\
\text { ные брови, широкий } \\
\text { нос, укороченные } \\
\text { фаланги пальцев рук } \\
\text { и ног, экзема. }\end{array}$ \\
\hline $\begin{array}{l}\text { Делеция } \\
\text { 3q29 }\end{array}$ & $\begin{array}{l}\text { Делеция } \\
\text { 3q29 }\end{array}$ & - & $\begin{array}{l}\text { Умствен- } \\
\text { ная от- } \\
\text { сталость } \\
\text { средней } \\
\text { степени } \\
\text { тяжести }\end{array}$ & $\begin{array}{l}\text { Отме- } \\
\text { чаются } \\
\text { аути- } \\
\text { стиче- } \\
\text { ские } \\
\text { черты }\end{array}$ & $\begin{array}{l}\text { МАР: микроцефалия, } \\
\text { длинное узкое лицо, } \\
\text { большие ушные } \\
\text { раковины, аномаль- } \\
\text { но сформированная } \\
\text { спинка носа, атак- } \\
\text { сия, пороки сердца } \\
\text { и почек. }\end{array}$ \\
\hline $\begin{array}{l}\text { Дупли- } \\
\text { кация } \\
4 \text { p16.3 }\end{array}$ & $\begin{array}{l}\text { Дупли- } \\
\text { кация } \\
\text { 4p16.3 }\end{array}$ & - & $\begin{array}{l}\text { Умствен- } \\
\text { ная от- } \\
\text { сталость } \\
\text { средней } \\
\text { степени } \\
\text { тяжести }\end{array}$ & $\begin{array}{l}\text { Встре- } \\
\text { чаются } \\
\text { аути- } \\
\text { стиче- } \\
\text { ские } \\
\text { прояв- } \\
\text { ления }\end{array}$ & $\begin{array}{l}\text { Задержка роста, } \\
\text { ЗПМР, ЗПРР, микро- } \\
\text { цефалия, лицевые } \\
\text { аномалии: высокий } \\
\text { лоб, низко распо- } \\
\text { ложенные ушные } \\
\text { раковины, короткая } \\
\text { шея, пороки ССС, } \\
\text { аномалии глазных } \\
\text { щелей, гипотония } \\
\text { с мышечной гипо- } \\
\text { трофией. }\end{array}$ \\
\hline
\end{tabular}


И.Ю. Юров, С.Г. Ворсанова, В.Ю. Воинова, М.И. Чурносов, Ю.Б. Юров

Продолжение табл. 2

\begin{tabular}{|c|c|c|c|c|c|}
\hline 1 & 2 & 3 & 4 & 5 & 6 \\
\hline $\begin{array}{l}\text { Вольфа- } \\
\text { Хирш- } \\
\text { хорна* }\end{array}$ & \begin{tabular}{|l} 
Делеция \\
4p16.3
\end{tabular} & $\begin{array}{c}1: 90000- \\
100000\end{array}$ & $\begin{array}{l}\text { Умствен- } \\
\text { ная от- } \\
\text { сталость } \\
\text { раз- } \\
\text { личной } \\
\text { степени } \\
\text { тяжести }\end{array}$ & - & $\begin{array}{l}\text { 3РР, ЗПМР, ЗПРР, } \\
\text { микроцефалия, } \\
\text { лицевые МАР: вы- } \\
\text { сокий лоб, анома- } \\
\text { лии глазных щелей, } \\
\text { гипертелоризм, } \\
\text { клювовидный нос } \\
\text { с выступающим над- } \\
\text { переносьем, микро- } \\
\text { гения, низко рас- } \\
\text { положенные ушные } \\
\text { раковины, короткая } \\
\text { шея, гипоспадия, } \\
\text { крипторхизм, тонкие } \\
\text { конечности, гипо-- } \\
\text { тония с мышечной } \\
\text { гипотрофией; часто } \\
\text { встречаются пороки } \\
\text { ССС и почек. }\end{array}$ \\
\hline $\begin{array}{l}\text { «крика } \\
\text { кошки»* }\end{array}$ & \begin{tabular}{|l} 
Делеция \\
5p12
\end{tabular} & $\begin{array}{c}1: 15000- \\
1: 50000\end{array}$ & $\begin{array}{l}\text { Ум- }_{\text {м }} \\
\text { ственная } \\
\text { отста- } \\
\text { лость от } \\
\text { умерен- } \\
\text { ной до } \\
\text { тяжёлой } \\
\text { степени }\end{array}$ & $\begin{array}{l}\text { Аути- } \\
\text { стиче- } \\
\text { ские } \\
\text { черты }\end{array}$ & $\begin{array}{l}\text { Нарушение поведе- } \\
\text { ния, повторяющиеся } \\
\text { движения, изменения } \\
\text { гортани и надгор- } \\
\text { танника, микроце- } \\
\text { фалия, микрогения, } \\
\text { низко расположен- } \\
\text { ные ушные ракови- } \\
\text { ны, гипертелоризм } \\
\text { и антимонголоидный } \\
\text { разрез глазных щелей, } \\
\text { косоглазие. }\end{array}$ \\
\hline $\begin{array}{l}\text { Дупли- } \\
\text { кация } \\
7 \text { p22.1 }\end{array}$ & \begin{tabular}{|l} 
Дупли- \\
кация \\
7 p22.1
\end{tabular} & - & $\begin{array}{l}\text { Умствен- } \\
\text { ная отста- } \\
\text { лость раз- } \\
\text { личной } \\
\text { степени } \\
\text { тяжести }\end{array}$ & Аутизм & $\begin{array}{l}\text { Черепно-лицевые } \\
\text { аномалии: макроце- } \\
\text { фалия, гипертело- } \\
\text { ризм глазных щелей, } \\
\text { аномалии ушных } \\
\text { раковин. }\end{array}$ \\
\hline
\end{tabular}


Продолжение табл. 2

\begin{tabular}{|c|c|c|c|c|c|}
\hline 1 & 2 & 3 & 4 & 5 & 6 \\
\hline $\begin{array}{l}\text { Вильям- } \\
\text { са }\end{array}$ & $\begin{array}{l}\text { Делеция } \\
\text { 7q11.23 }\end{array}$ & $\begin{array}{c}1: 10000 \\
\text { до } \\
1: 20000\end{array}$ & $\begin{array}{l}\text { Уме- } \\
\text { ренная } \\
\text { умствен- } \\
\text { ная от- } \\
\text { сталость } \\
\text { (средний } \\
\text { IQ 58-69) }\end{array}$ & $\begin{array}{l}\text { Неко- } \\
\text { торые } \\
\text { аути- } \\
\text { стиче- } \\
\text { ские } \\
\text { прояв- } \\
\text { ления }\end{array}$ & $\begin{array}{l}\text { СДВГ, тревожность, } \\
\text { мышечная гипото- } \\
\text { ния, макрокрания, } \\
\text { макроцефалия, МАР: } \\
\text { широкий лоб, глубо- } \\
\text { ко посаженные глаза, } \\
\text { широкая короткая } \\
\text { переносица, оттопы- } \\
\text { ренные ушные рако- } \\
\text { вины; пороки ССС. }\end{array}$ \\
\hline $\begin{array}{l}\text { Делеция } \\
11 \mathrm{q} 13\end{array}$ & $\begin{array}{l}\text { Делеция } \\
11 \mathrm{q} 13\end{array}$ & - & - & $\begin{array}{l}\text { Рас- } \\
\text { строй- } \\
\text { ства } \\
\text { аути- } \\
\text { стиче- } \\
\text { ского } \\
\text { спектра }\end{array}$ & $\begin{array}{l}\text { ЗПРР, МАР: синоф- } \\
\text { риз, широкий нос, } \\
\text { ретрогнатия, широкие } \\
\text { пальцы с короткими } \\
\text { дистальными фалан- } \\
\text { гами. }\end{array}$ \\
\hline $\begin{array}{l}\text { Дупли- } \\
\text { кации } \\
15 q 11 q 13\end{array}$ & $\begin{array}{l}\text { Дупли- } \\
\text { кация } \\
\text { 15q11q13 }\end{array}$ & - & $\begin{array}{l}\text { Умствен- } \\
\text { ная от- } \\
\text { сталость } \\
\text { раз- } \\
\text { личной } \\
\text { степени } \\
\text { тяжести }\end{array}$ & Аутизм & $\begin{array}{l}\text { Различные психиче- } \\
\text { ские расстройства. }\end{array}$ \\
\hline $\begin{array}{l}\text { Ангель- } \\
\text { мана }\end{array}$ & $\begin{array}{l}\text { Делеция } \\
15 q 11.2 \\
\text { на хро- } \\
\text { мосоме } \\
\text { матери }\end{array}$ & $\begin{array}{c}1: 12000- \\
1: 20000\end{array}$ & $\begin{array}{l}\text { Тяжёлая } \\
\text { степень } \\
\text { умствен- } \\
\text { ной от- } \\
\text { сталости }\end{array}$ & $\begin{array}{l}\text { Аути- } \\
\text { стиче- } \\
\text { ские } \\
\text { прояв- } \\
\text { ления }\end{array}$ & $\begin{array}{l}\text { Нарушения речи, } \\
\text { походки, координа- } \\
\text { ции, концентрации } \\
\text { внимания; гиперак- } \\
\text { тивность, импульсив- } \\
\text { ность; эпилепсия, } \\
\text { атаксия, умственная } \\
\text { отсталость, характер- } \\
\text { ные лицевые микро- } \\
\text { аномалии. }\end{array}$ \\
\hline
\end{tabular}


И.Ю. Юров, С.Г. Ворсанова, В.Ю. Вочнова, М.И. Чурносов, Ю.Б. Юров

Продолжение табл. 2

\begin{tabular}{|c|c|c|c|c|c|}
\hline 1 & 2 & 3 & 4 & 5 & 6 \\
\hline $\begin{array}{l}\text { Пра- } \\
\text { дера - } \\
\text { Вилли }\end{array}$ & $\begin{array}{l}\text { Делеция } \\
15 q 11.2 \\
\text { на хро- } \\
\text { мосоме } \\
\text { отца }\end{array}$ & $\begin{array}{c}1: 15000- \\
1: 30000\end{array}$ & $\begin{array}{l}\text { Уме- } \\
\text { ренная } \\
\text { умствен- } \\
\text { ная от- } \\
\text { сталость } \\
\text { (средний } \\
\mathrm{IQ}-60)\end{array}$ & $\begin{array}{l}\text { Рас- } \\
\text { строй- } \\
\text { ства } \\
\text { аути- } \\
\text { стиче- } \\
\text { ского } \\
\text { спектра }\end{array}$ & $\begin{array}{l}\text { Дизлексия, риту- } \\
\text { альное поведение, } \\
\text { компульсивные } \\
\text { симптомы, по- } \\
\text { вышенный риск } \\
\text { психических на- } \\
\text { рушений; различ- } \\
\text { ные психические } \\
\text { расстройства. }\end{array}$ \\
\hline $\begin{array}{l}\text { Делеция } \\
15 q 24\end{array}$ & \begin{tabular}{|l} 
Делеция \\
$15 \mathrm{q} 24$
\end{tabular} & - & $\begin{array}{l}\text { Умствен- } \\
\text { ная от- } \\
\text { сталость }\end{array}$ & - & $\begin{array}{l}\text { Низкорослость, } \\
\text { микроцефалия, по- } \\
\text { ниженный мышечный } \\
\text { тонус (гипотония), } \\
\text { скелетные аномалии, } \\
\text { гипоспадия. }\end{array}$ \\
\hline $\begin{array}{l}\text { Делеции } \\
16 \text { p11.2 }\end{array}$ & \begin{tabular}{|l} 
Делеция \\
16 p11.2
\end{tabular} & - & $\begin{array}{l}\text { Умствен- } \\
\text { ная от- } \\
\text { сталость }\end{array}$ & Аутизм & $\begin{array}{l}\text { ЗРР, эпилепсия, низ- } \\
\text { кий рост, низко рас- } \\
\text { положенные ушные } \\
\text { раковины, частично } \\
\text { перепончатые пальцы, } \\
\text { пороки сердца, ожи- } \\
\text { рение. }\end{array}$ \\
\hline $\begin{array}{l}\text { Смит - } \\
\text { Маже- } \\
\text { нис }\end{array}$ & \begin{tabular}{|l} 
Делеция \\
$17 \mathrm{p} 11.2$
\end{tabular} & $\begin{array}{c}1: 15000- \\
1: 25000\end{array}$ & $\begin{array}{l}\text { Ум- } \\
\text { ственная } \\
\text { отста- } \\
\text { лость от } \\
\text { умерен- } \\
\text { ной до } \\
\text { тяжёлой } \\
\text { степени }\end{array}$ & $\begin{array}{l}\text { Неко- } \\
\text { торые } \\
\text { аути- } \\
\text { стиче- } \\
\text { ские } \\
\text { прояв- } \\
\text { ления } \\
\text { варьи- } \\
\text { руют }\end{array}$ & $\begin{array}{l}\text { Нарушение поведе- } \\
\text { ния, агрессия, резкая } \\
\text { смена настроения, } \\
\text { СДВГ, низкий рост, } \\
\text { МАР: брахицефалия, } \\
\text { широкие переносица } \\
\text { и лицо, синофриз. }\end{array}$ \\
\hline
\end{tabular}


Окончание табл. 2

\begin{tabular}{|c|c|c|c|c|c|}
\hline 1 & 2 & 3 & 4 & 5 & 6 \\
\hline $\begin{array}{l}\text { Делеции } \\
22 \text { q11.2 }\end{array}$ & $\begin{array}{l}\text { Делеция } \\
22 \mathrm{q} 11.2\end{array}$ & $1: 4000$ & $\begin{array}{l}\text { Умствен- } \\
\text { ная от- } \\
\text { сталость }\end{array}$ & Аутизм & $\begin{array}{l}\text { ЗПМР, ЗПРР, МАР: } \\
\text { расщелина губы } \\
\text { и нёба, снижение слу- } \\
\text { ха; пороки ССС. }\end{array}$ \\
\hline \begin{tabular}{|l} 
Делеции \\
22q13.3 \\
(син- \\
дром \\
Фелан- \\
Мак \\
Дермид)
\end{tabular} & $\begin{array}{l}\text { Делеция } \\
22 \mathrm{q} 13.3\end{array}$ & - & - & Аутизм & $\begin{array}{l}\text { Неонатальная гипо- } \\
\text { тония, задержка или } \\
\text { полное отсутствие } \\
\text { речи, эпилепсия, } \\
\text { МАР: большие ушные } \\
\text { раковины, дис- } \\
\text { пластичные ногти, } \\
\text { широкий лоб, острый } \\
\text { подбородок. }\end{array}$ \\
\hline
\end{tabular}

*Синдромы Вольфа-Хиршхорна и «крика кошки» относятся к делеционным синдромам, но в данной таблице речь идёт о микроперестройках в делетированных хромосомах (микроделеции), затрагивающих критический участок синдрома.

\subsection{3. Мультифакторные (многофакторные) бодезни}

Френсис Гальтон (Francis Galton, 1822-1991 гг.) и его последователи ещё в середине 19 века пришли к заключению о том, что такие признаки, как рост и цвет кожи, могут быть обусловлены взаимодействием многих генов, каждый из которых оказывает определенный аддитивный эффект («аддитивный эффект» - от английского слова «addition» - дополнение) - вид синергизма, при котором эффект действия генов совместно равен сумме эффектов действия каждого в отдельности. Это контрастирует с характеристиками моногенного наследования, при котором действие одного гена является независимым и неаддитивным. Такая модель широко используется для объяснения наследования при многих врождённых аномалиях (например, расщелина губы и нёба), и часто встречающихся в популяции заболеваний (например, сахарный диабет, гипертоническая болезнь). Эти болезни с наследственным предрасположением являются наиболее 
распространёнными заболеваниями, генетика которых носит полигенный характер. Болезни, в которых принимает участие множество генов (полигенная основа) и средовые факторы, получили название мультифакторных или многофакторных заболеваний, ранее ошибочно называемых мультифакториальными. Согласно последним данным к ним относится большинство заболеваний человека (около 80-90\%). Следует отметить, что к ним могут быть отнесены практически все болезни, за исключением наследственной патологии, вызванной генными и хромосомными мутациями, а также травматические и инфекционные заболевания. Причём восстановительные процессы после травмы и действия инфекций также, как и воздействие факторов окружающей среды, в определённой степени зависят от генотипа. Изучением влияния факторов окружающей среды на наследственный аппарат клетки занимается экологическая генетика. Среди множества внешнесредовых факторов окружающей среды особое место принадлежит лекарственным препаратам. Изучением роли наследственных факторов в формировании реакций организма на лекарственные препараты занимается фармакогенетика. Знание основ экологической генетики и фармакогенетики является значительным вкладом в профилактику и лечение многофакторных заболеваний (см рекомендуемую литературу).

\subsection{4. Митохондриадыные бодезни}

Митохондриальные болезни относятся к особому классу наследственной патологии, связанному с митохондриальным (цитоплазматическим) типом наследования. Изучение этих заболеваний берёт начало в 60-х годах прошлого столетия. Так, в 1962 году P. Лафт (R. Luft) с соавторами обратил внимание на ассоциацию тяжелой мышечной недостаточности с нарушением процессов окислительного фосфорилирования в митохондриях мышечной ткани. Первые сообщения о мутациях митохондриальной ДНК (мтДНК) у больных с миопатиями были сделаны в 1988 году. Известно, что каждая клетка содержит тысячи копий митохондриальной ДНК. Благодаря успехам секвенирования было сформулировано представление о митохондриальных болезнях как 
о состояниях, обусловленных дефектами мтДНК. Появился термин «митохондриальные миопатии», а в 1998 году выявлены мутации генов ядерной ДНК, связанные также с этими миопатиями. Ряд редких болезней с необычной комбинацией неврологических и миопатических признаков, кардиомиопатии, диабет, как оказалось, возникают вследствие мутаций митохондриальных генов. Неудивительно, что головной мозг, мышцы и сердце поражаются в большей степени, поскольку эти органы наиболее энергозависимы. Митохондриальные болезни поражают оба пола, но передаются только через женщин.

\subsection{5. Вклад генетических болезней в структуру заболеваемости}

Среди причин многих болезней растет вклад генетических факторов. Для определенных заболеваний (например, манифестирующих в перинатальном периоде) этот рост является незначительным, поскольку благодаря достижениям медицины уменьшается вклад таких причин, как инфекции. Но для ряда хронических нервных и психических болезней (шизофрении или аутизма) общий вклад генетических причин постоянно увеличивается. Влияние генетических факторов на здоровье может быть оценено, исходя из приведённых ниже наблюдений.

Заболевания новорожденных. Среди новорожденных 2-3\% имеют, по крайней мере, один врождённый порок развития. Около половины пороков у новорожденных вызваны генетическими факторами. Частота хромосомных аномалий у этой категории детей составляет 1:200.

Заболевания у детей в возрасте от 1 месяща до 18 лет. В основе не менее $25 \%$ случаев смерти детей в возрасте до года лежат наследственные и врождённые заболевания. Генетические болезни составляют $50 \%$ причин слепоты и глухоты, и более трети тяжелых когнитивных нарушений у детей. В развитых странах врождённые и наследственные заболевания вместе составляют около $30 \%$ госпитализаций, и 40-50\% смертных случаев зарегистрировано в детском возрасте. 
Заболевания взрослых. Наследственные болезни поражают около $5 \%$ популяции к возрасту 25 лет. Принимая во внимание вклад наследственности в кардиоваскулярные, онкологические и психические заболевания, можно считать, что свыше половины популяции развитых стран страдает генетически обусловленными заболеваниями. Для лечения и профилактики болезней, встречающихся в практике врачей всех специальностей, необходимо знать механизмы взаимодействия средовых и наследственных факторов в их возникновении и развитии.

Таким образом, на рубеже XX и XXI веков медицинская генетика заняла лидирующее место в медицине и биологии и стала оказывать значительное влияние на развитие многих наук, включая различные направления медицины, биологии и психологии.

В настоящее время следует особо отметить интенсивное изучение наследственной патологии с внедрением современных молекулярно-цитогенетических технологий в клиническую практику, что вносит значительный вклад в диагностику и профилактику генетических заболеваний.

\section{ГДава 2. МОЯЕКУ ЯЯРНЫЕ ОСНОВЫ НАС ЛЕДСТВЕННОСТИ}

Генетическая информация закодирована в последовательности макромолекулы дезоксирибонуклеиновой кислоты (ДНК), которая представляет собой полимер, состоящий из мономеров - нуклеотидов. Молекула ДНК, взаимодействуя со специфическими белками (хромосомными белками - гистонами и негистоновыми белками), а также с рибонуклеиновой кислотой (РНК), образует хроматин, который представляет собой структурную основу хромосом - нитевидных структур, основных супрамолекулярных носителей наследственной информации. Соматические клетки (все клетки организма, кроме половых) в норме имеют клеточное ядро с 23 парами гомологичных хромосом (46 хромосом) - диплоидный хромосомный набор. 
Гень - фундаментальные единицы наследственности - находятся в каждой хромосоме. Они являются линейными последовательностями ДНК, кодирующими молекулы белков, необходимых для нормального развития и жизнедеятельности организма. Преемственность генетической информации от клетки к клетке и от организма к организму осуществляется за счет копирования хромосомной ДНК (репликации) и передачи наследственной информации во время клеточного деления (митотического и мейотического деления).

\section{1. Структура ДНК}

Молекула ДНК представляет собой двойную спираль: две параллельные цепи нуклеотидов, закрученные относительно друг друга и поддерживающие свою структуру за счет водородных связей. Нуклеотид является органическим соединением, состоящим из дезоксирибозы (углеводной функциональной группы), фосфатной группы и одного из 4-х азотистых оснований (гетероциклических соединений): аденина (А), гуанина (Г), цитозина (Ц) или тимина (T). Аденин и гуанин являются пуриновыми гетероциклическими соединениями, тогда как цитозин и тимин - пиримидиновыми. ДНК образуется за счет того, что дезоксирибозная компонента и фосфатная группа каждого из нуклеотидов последовательно связываются, образуя остов спиральной молекулы, к которому присоединяются азотистые основания. Каждый пятый атом углерода (5') дезоксирибозной компоненты нуклеотида связывается с каждым третьим атомом углерода (3') последующего нуклеотида посредством ковалентных связей с фосфатной группой. Комплементарные азотистые основания (А комплементарен Т, а Г - Ц) образуют друг с другом водородные связи - процесс спаривания нуклеотидов. Двунитевая молекула ДНК - антипараллельна, т. е. последовательность нуклеотидов одной нити является обратной последовательности другой. Это является причиной того, что макромолекула ДНК спиральна, а также гарантирует возможность образования однонитевой ДНК, которая необходима для корректного воспроизведения последовательностей ДНК в ходе их копирования или репликации. Следует 
также отметить, что соотношения количества нуклеотидов А:Т и Г:Ц в клетках любого организма составляют 1:1 (правило Чаргаффа).

\section{2. Синтез ДНК}

Процесс синтеза новых молекул ДНК называется репликацией (рис. 3). Первой стадией этого процесса является разрыв водородных связей между нуклеотидами и образование однонитевых последовательностей ДНК при воздействии ферментов ДНКхеликаз и других специфических белков, которые сохраняют структуру ДНК в ходе репликации. Участком образования однонитевой ДНК, которая служит матрицей (матричная нить) для копирования ДНК, является структура в виде латинской буквы Y, называемая репликационной вилкой. Обе матричные нити создают основу для синтеза новых последовательностей ДНК согласно правилу комплементарности Чаргаффа. Комплементарные нуклеотиды присоединяются к 3' концу образующейся последовательности ДНК за счет взаимодействия ДНК полимеразы I на одной матричной нити (непрерывный синтез ДНК), тогда как синтез ДНК на другой матричной нити происходит за счет образования небольших двунитевых последовательностей ДНК, фрагментов Оказаки (прерывистый синтез ДНК). После разделения двух матричных нитей фермент ДНК праймаза использует рибонуклеотиды (мономеры макромолекулы РНК) для формирования РНKзатравки (небольшие последовательности РНК, участвующие в процессе репликации).

Рибонуклеиновая кислота (РНК) отличается от ДНК тем, что (1) она - однонитевой полимер, (2) углеводная компонента РНК представляет собой рибозу, (3) вместо тимина в её последовательность входит урацил (У). Небольшие последовательности РНК располагаются в начале каждого нового фрагмента Оказаки, и играют значимую роль в обеспечении прерывистого синтеза ДНК, затем ДНК полимераза I присоединяет нуклеотиды в прерванной последовательности (между фрагментами Оказаки) на матричной нити и удаляет эти последовательности РНК. Далее, фермент ДНКлигаза связывает (сшивает) разрозненные фрагменты Оказаки и образует дочернюю двунитевую последовательность 
ДНК. Процесс репликации является полуконсервативным, поскольку в ходе его образуются две идентичные двунитевые молекулы ДНК, в каждой из которых одна нить - матричная, а другая - новообразованная.
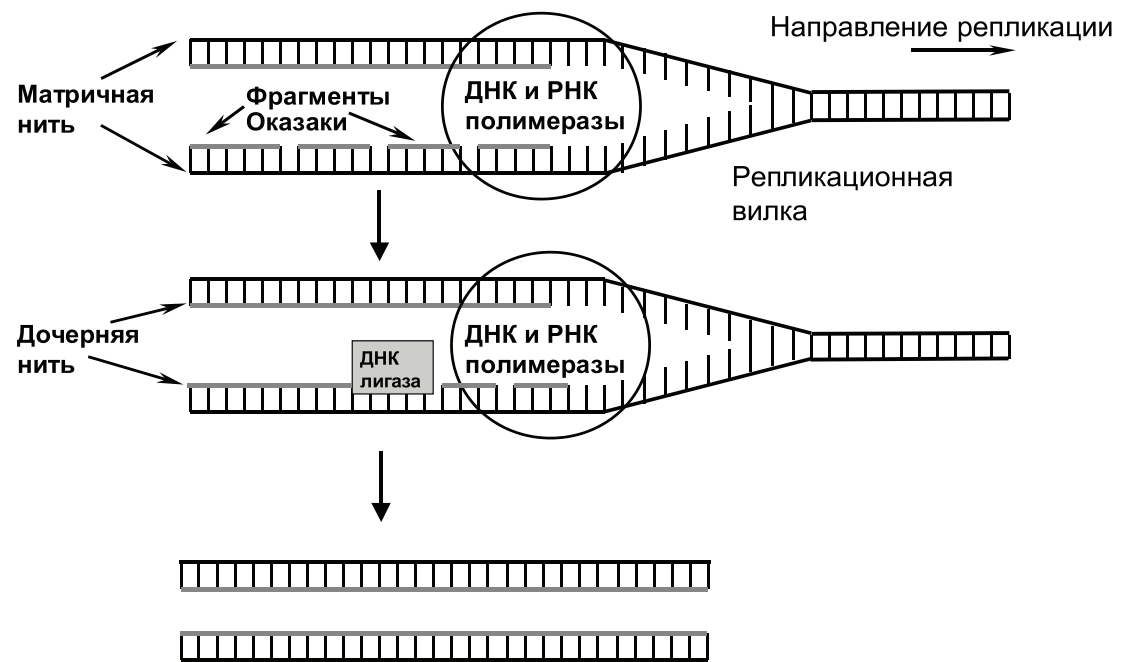

Рис. 3. Полуконсервативная репликация ДНК.

Комплиментарные нуклеотиды присоединяются к 3' концу матричной нити, а дочерняя нить реплицируется за счет образования фрагментов Оказаки

\section{3. Синтез белка}

Информация о последовательностях молекул белка закодирована в линейной последовательности азотистых оснований нуклеиновых кислот в виде триплетов. Каждый триплет кодирует определенный аминокислотный остаток (аминокислоту), последовательная цепь (полипептидная цепь) которого впоследствии формирует молекулы белка.

Синтез белка начинается с процесса транскрипции. В ходе этого процесса на основе молекул ДНК по принципу комплиментарности синтезируются молекулы матричной РНК (мРНК) 
с помощью фермента РНК полимеразы. Присоединение РНК полимеразы к началу последовательности ДНК гена инициирует транскрипцию. Синтез мРНК происходит по мере продвижения РНК полимеразы по последовательности ДНК гена. Затем, в ходе транскрипции происходит модификация мРНК (РНК прощессинг), которая необходима для дальнейших биохимических процессов, лежащих в основе синтеза белка.

Гены состоят как из последовательностей ДНК, кодирующих аминокислотные остатки (экзоны), так и некодирующих последовательностей (интронов). РНК процессинг включает в себя удаление мРНК, синтезированной на основе интронов. Некоторые нуклеотиды также удаляются с 3' конца молекулы, и к этому концу присоединяется последовательность, состоящая исключительно из аденина (полиадениновая последовательность или поли(A). Она необходима для транспортировки молекул мРНК за пределы клеточного ядра в цитоплазму. В ходе РНК процессина модифицируются также нуклеотиды мРНК в 5' положении и происходит так называемое кэпирование (образование кэпа) - метилирование гуанина и последующих пуриновых азотистых оснований. Это необходимо для присоединения мРНК к рибосоме. Рибосомы состоят из рибосомальной РНК и белковой компоненты. Они представляют собой клеточные структуры, на которых происходит синтез белка. Имея две субъединицы, между которыми располагается мРНК, они считывают закодированную в ней информацию о последовательности аминокислотных остатков в белковой молекуле. Следующей стадией синтеза белков является транслящия. Полипептидная цепь (последовательность аминокислотных остатков) синтезируется во время этой стадии на базе мРНК посредством другого типа РНК, транспортной РНК (тРНК). В её состав входят антикодоны - тринуклеотиды, которые комплементарны триплетам мРНК, другие специфические последовательности РНК и аминокислотный остаток. После считывания кодона мРНК рибосомой он взаимодействует с антикодоном тРНК, в структуру которой входит соответствующий аминокислотный остаток. Далее происходит образование пептидных 
связей между считанными аминокислотными остатками до обнаружения стоп-кодона - сигнала завершения синтеза белка.

Следует упомянуть также понятие вырожденности генетического кода, которое используется для обозначения того факта, что аминокислотные остатки кодируются несколькими триплетами: различные комбинации 4-х азотистых оснований дают 64 триплета, 61 из них кодирует аминокислотные остатки, число которых составляет 20, три стоп-кодона останавливают белковый синтез.

\section{4. Вариации генома человека: генные мутации}

В основе практически всех генетических исследований лежит понятие вариации. Это понятие включает в себя все типы изменений последовательностей ДНК (мутащий), наблюдаемых на генном, хромосомном или геномном уровнях. С одной стороны, вариации генома служат объяснением межиндивидульного разнообразия, с другой, мутации могут приводить к патогенным изменениям жизнедеятельности организма, являясь, таким образом, причиной наследственного заболевания. Следует также ввести несколько терминов, использующихся для описания процесса мутационного изменения ДНК: локус определенный участок хромосомы, содержащий специфические последовательности ДНК или гены, аллель - две или более альтернативных форм гена, расположенных в одном и том же локусе пары гомологичных хромосом. Если различие последовательности ДНК двух аллелей одного локуса наблюдается с частотой более $1 \%$ в общей популяции, то данный тип вариации обозначается полиморфизмом. Изменение последовательности ДНК, имеющее меньшую частоту, как правило, называется мутащией. Известны два основных вида мутаций, связанных с наследственной патологией: хромосомные (геномные) - изменение числа и/или структуры хромосом (генома) в клетке и генные (изменение последовательности ДНК в конкретном гене). Исходя из данной классификации, можно выделить направления генетических исследований нарушений последовательности ДНК, приводящих к наследственным заболеваниям, которые изучает медицинкая генетика, а именно, поиск 
изменений последовательностей нуклеиновых кислот и белков на молекулярном уровне (молекулярная генетика) и изучение изменений числа, структуры и организации хромосом (классическая и молекулярная цитогенетика).

Молекулярно-генетические исследования основаны на современных представлениях об особенностях молекулы ДНК и биохимических процессах транскрипции и трансляции. Основная их цель заключается в выявлении генных мутаций, приводящих к характерным фенотипическим проявлениям. Генные мутации представляют собой изменение расположения, потерю и приобретение ДНК относительно её линейной последовательности, обнаруживаемой в норме. Наиболее частыми типами генных мутаций являются замена, потеря и/или вставка одного нуклеотида. Последние изменения обозначаются аббревиатурой $\boldsymbol{S N P}$ (single nucleotide polymorphisms) и проявляются наиболее часто в геноме человека. В среднем, SNP, ведущие к вариации между аллелями у одного индивидуума, встречаются в каждых из 1500 пар нуклеотидов. Однако, большинство из них расположены в некодирущих последовательностях и, в основном, не имеют фенотипических последствий. Если изменение последовательности ДНК происходит в гене, кодирующем белок, то оно с высокой долей вероятности будет связано с нарушениями жизнедеятельности организма. Существует следующая классификация генных мутаций:

Миссенс мутации - замена одного нуклеотида на другой или несинонимические изменения последовательности ДНК. Теоретически можно выделить два типа подобных мутаций: консервативные и неконсервативные. Консервативные миссенс мутации приводят к замене одного кодона на равнозначный (кодоны, кодирующие один и тот же аминокислотный остаток) или на кодон другого аминокислотного остатка, который не изменяет физико-химические свойства белка, кодированного соответствующим геном. Неконсервативные миссенс мутации, как правило, изменяют биохимические свойства белка и, следовательно, приводят к нарушению его функциональной активности. 
Нонсенс мутации - изменения кодирующей последовательности ДНК, приводящие к образованию стоп-кодона, вследствие чего синтезируется белок, в котором отсутствует какая-то часть его последовательности.

Мутация сдвига рамки сиитывания - любые изменения последовательности ДНК гена (в основном, потери или вставки нуклеотидов), которые приводят к сдвигу считывания последовательности в ходе транскрипции. Результатом этого является синтез совершенно нового белка или образование матричной РНК, не несущей в себе никакой информации относительно аминокислотной последовательности.

Непатогенные изменения последовательности ДНК - вариации последовательности ДНК, включающие консервативные миссенс мутации, или так называемые синонимические мутации, которые не изменяют закодированную информацию в ДНК гена или не воздействуют на функциональную активность белковых макромолекул.

Мутации также происходят в некодирующих последовательностях ДНК (интронах). Данный тип вариаций, как правило, не имеет фенотипических последствий. Тем не менее, при сдвиге рамки считывания или образовании альтернативных форм белковых макромолекул (альтернативный сплайсинг), эти вариации могут приводить к нарушению функциональной активности белковых макромолекул и, как следствие, фенотипическим последствиям. В данном контексте сложностью представляется идентификация патогенных мутаций, так как понятие «нормы» для медико-генетических исследований затруднено в силу того, что на молекулярном уровне геном человека является в значительной степени нестабильным. Иными словами, только рекуррентные мутации (наиболее частые повторные мутации, которые выявляются у индивидуумов с известным наследственным заболеванием) могут быть признаны патогенными. В случаях, когда обнаруживается новая мутация, возникает необходимость молекулярно-генетических исследований близких родственников пациента, чтобы определить, является ли она причиной заболевания. 


\section{5. Эпигенетические процессы и наследственные болезни}

В исследованиях генетических процессов, связанных с патогенезом заболеваний, особое внимание уделяется не только изменениям последовательностей ДНК, но также и транскрипционной активности ДНК в клетке. Вариация активности генома (экспрессия генов) как в отдельно взятой клетке, так и во всем организме достигается за счет различных эпигенетических процессов. Эпигенетические процессы представляют собой наследуемые изменения в экспрессии генов, нарушающие законы Менделя, без количественного или качественного (мутационного) изменения последовательности ДНК. В настоящее время описан целый ряд эпигенетических феноменов и процессов, таких как инактивация хромосомы $\mathrm{X}$, геномный импринтинг, унипарентальная дисомия, изменение порядка репликации ДНК, метилирование ДНК, биохимическая модификация гистонов и другие. Изучает подобные процессы особое направление в генетике - эпигенетика. Наиболее изученными эпигенетическими процессами являются модификация химической структуры ДНК за счет метилирования цитозина динуклеотидов в 5'-положении, приводящего к транскрипционной инактивации генов, а также различные биохимические модификации гистоновых белков, образующих хроматин, которые могут приводить как к инактивации, так и к активации генов. Следует отметить, что эпигенетические механизмы лежат в основе нормальной активности клетки, тогда как нарушение этих процессов приводит к целому ряду функциональных аномалий различных тканей организма, среди которых наиболее часто встречаются пороки развития центральной нервной системы. Наиболее подробно изученным эпигенетическим феноменом является процесс инактивации хромосомы $X$.

Женский кариотип характеризуется наличием двух половых хромосом $\mathrm{X}$, а мужской - половыми хромосомами (гоносомами) X и Ү. Этот факт свидетельствует о несоответствии содержания генетической информации у лиц мужского и женского пола. У человека, как и у других млекопитающих, этот дисбаланс экспрессии генов разрешается благодаря инактивации 
одной из хромосом X во всех клетках организма. Предположение о возможной инактивации генов хромосомы X было впервые предложено после исследования конденсированных хроматиновых структур в клетках млекопитающих. На внутриклеточном уровне данный процесс сопровождается образованием исключительно стабильной гетерохроматиновой структуры - одной или нескольких инактивированных хромосом Х. В зависимости от их количества в клетке определяется анеуплоидия хромосомы X. Селективность процесса инактивации хромосомы X является произвольной. В результате у большинства женских особей наблюдается мозаичная экспрессия материнских и отцовских аллелей локусов хромосомы Х. В среднем вклад каждой хромосомы должен составлять примерно $50 \%$, но поскольку процесс Х-инактивации случайный, то он теоретически может значительно варьировать. Инактивированная хромосома $\mathrm{X}$ характеризуется следующими свойствами: полной транскрипционной инактивацией большинства Х-сцепленных генов; конденсацией гетерохроматина в интерфазе; поздней репликацией инактивированной хромосомы $\mathrm{X}$ в $\mathrm{S}$ фазе деления клетки; метилированием цитозина ЦГ динуклеотидов в 5'-положении в генах, подверженных транскрипционной инактивации; химической модификации гистоновых белков (гипоацетилирование), приводящей к транскрипционной инактивации генов, а также некоторыми другими особенностями, которые приводят к образованию и сохранению стабильности на протяжении клеточного цикла, связанного с факультативным гетерохроматином (неактивной хромосомой X). Особое место занимает экспрессия гена XIST (X-inactive specific transcript) на инактивированной хромосоме, продуктом которой является ядерная или хромосомная РНК, покрывающая инактивированную хромосому $\mathrm{X}$ и участвующая в структурной организации факультативного гетерохроматина или неактивной хромосомы X.

Несмотря на то, что вклад каждой хромосомы X (отцовской и материнской) должен составлять примерно $50 \%$, у значительного числа женщин наблюдается инактивация преимущественно одной из родительских хромосом X - неравная X-инактивация или 
сдвиг $X$-инактивации. Известны следующие механизмы инактивации хромосомы $X$, приводящие к случайной (равной) [1] и неравной Х-инактивации [2 и 3]:

1) процесс, приводящий к случайной X-инактивации, следующий: отцовская или материнская хромосома X независимо инактивируется в каждой клетке на ранних стадиях развития плода. Инактивация генов сохраняется за счет метилирования цитозина на неактивной хромосоме Х. Таким образом, достигается практически эквивалентная (50:50) экспрессия генов отцовской и материнской хромосом Х в организме;

2) процесс, приводящий к неслучайной X-инактивации, следующий: одна из хромосом X (отцовская или материнская) имеет летальную мутацию, что препятствует дальнейшему развитию клеток, в которых хромосома Х с мутацией активна. В результате чего, в организме присутствуют преимущественно клетки, в которых мутированная хромосома X неактивна, и, таким образом, в организме наблюдается неравная X-инактивация;

3) процесс, приводящий к неслучайной Х-инактивации, может быть следующий: мутации в гене XIST приводят к тому, что выбор активной хромосомы Х неслучайный.

Неравная инактивация хромосомы Х представляется одной из особенностей ряда наследственных заболеваний. Болезни, связанные с ней, могут быть вызваны генными или хромосомными (геномными) мутациями, а также внешними факторами, при которых наблюдается неравная инактивация хромосомы X без мутаций. Эта группа заболеваний включает в себя болезни, связанные с Х-сцепленными рецессивными мутациями, большую часть которых составляет $\boldsymbol{X}$-сцепленная умственная отсталость, а также ряд мультифакторных заболеваний (например, аутизм).

Известным эпигенетическим феноменом, имеющим особое значение для медицинской генетики - генетики нервных и психических болезней, является полиморфизм генов или SNP (single nucleotide polymorphisms), приводящий к изменению последовательности ДНК, связанному с изменением функциональной активности закодированного белка. В настоящее время описано несколько подобных генов, полиморфные варианты которых имеют 
повышенную частоту среди больных нервными и психическими болезнями, например, гены, кодирующие серотониновые и допаминовые рецепторы при шизофрении. Несмотря на то, что этот феномен все же связан с изменением последовательности ДНК, тот факт, что они являются синонимическими мутациями, позволяет рассматривать подобные вариации экспрессии генов в рамках эпигенетики.

Определённые участки гомологичных хромосом не являются функционально одинаковыми. Локусы в таких участках могут показывать различия их активности в зависимости от материнского и отцовского происхождения. Так, определённые гены в зависимости от того, на какой хромосоме (материнской или отцовской) они расположены, вносят различный вклад в развитие эмбриона. Такие специфические различия в регуляции генов в зависимости от родительского происхождения определяются как геномный импринтинг.

Геномный импринтинг может вовлекать генные локусы либо отцовского, либо материнского происхождения. Так, в соматических клетках человека как у мужчин, так и у женщин отцовская последовательность ДНК гомологичных хромосом может быть активна, в то время как материнская последовательность ДНК инактивирована. Геномный импринтинг и унипарентальная дисомия (см ниже) являются причиной ряда таких заболеваний, как синдром Прадера-Вилли и Ангельмана, связанных с локусами длинного плеча (q) хромосомы 15. Геномный импринтинг также зависит от особенностей метилирования в зависимости от родительского происхождения хромосом (различное метилирование локусов родительских хромосом). Например, если ген материнского происхождения метилирован (инактивирован), а этот же ген отцовского происхождения не является метилированным, то только отцовский ген будет экспрессироваться. Так как импритинг стирается в половых клетках, то гомологичные гены становятся метилированными в женских половых клетках, а в мужских половых клетках - неметилированными, в результате чего в зиготе наблюдается различие в метилировании аллелей импринтированных генов. Особенно хорошо демонстрирует феномен геномного импринтинга один из участков хромосомы 7 у мыши. Если 
одна третья часть обеих хромосом 7 в эмбрионе мыши отцовского происхождения, то мышь будет иметь большие размеры тела. Напротив, если материнского, то эмбрионы будут иметь маленькие размеры по сравнению с нормой и погибнут в ходе эмбрионального развития. Это объясняется различиями инактивации гена инсулин-подобного фактора роста-2 (IGF2), который расположен в этом участке и является особенно значимым для роста в эмбриональном развитии. Данный участок хромосомы 7 у мыши является гомологичным определенному участку короткого плеча хромосомы 11 у человека. Однородительская дисомия этого участка предрасполагает к наследственным синдромам, которые характеризуются клиникой синдрома Беквита-Видемана (большой размер тела и опухоль Вилмса). Другим примером однородительской дисомии являются синдромы Прадера-Вилли и Ангельмана, при которых наблюдается потеря функций в одном из хромосомных участков в зависимости от родительского происхождения. Синдромы Прадера-Вилли и Ангельмана являются клинически различными заболеваниями с нарушениями развития и поведения. Они вызваны потерей функции двух хромосомных участков, локализованных вблизи друг от друга на хромосоме 15. Эти два заболевания различаются клинической картиной вследствие потери функции, связанной с участком хромосомы либо отцовского, либо материнского происхождения. Это синдромы одного и того же участка одной хромосомы. Делеция этой части хромосомы 15 обнаруживается от $15 \%$ до $75 \%$ пациентов с синдромами Прадера-Вилли или Ангельмана. Если делеция затрагивает отцовскую хромосому, то это приводит к синдрому Прадера-Вилли и, наоборот, если материнскую - к синдрому Ангельмана. Для синдрома Прадера-Вилли характерны неонатальная гипотония, задержка развития, гиперфагия и ожирение, короткий рост, маленькие верхние и нижние конечности, гипогонадизм и гипопигментация. При синдроме Ангельмана делеция хромосомы 15 имеет материнское происхождение. Для этой болезни характерны следующие признаки: умственная отсталость с нарушением развития речи, дружеское расположение (ласковый смех без видимых причин), гиперактивное поведение, судороги, специфические изменения 
в ЭЭГ и гипопигментация. Имеются ДНК маркеры, позволяющие установить родительское происхождение делеции молекулярно-генетическими методами. При синдроме Прадера-Вилли отсутствует отцовский аллель, а при синдроме Ангельмана - материнский. Примерно до 30-35\% пациентов с синдромом Прадера-Вилли и 15-30\% с синдромом Ангельмана не имеют делеции. В этих случаях часто обнаруживают однородительскую дисомию у $30 \%$ детей с синдромом Прадера-Вилли и у $2 \%$ - с синдромом Ангельмана. У 1-2\% пациентов с синдромом Прадера-Вилли и у $20 \%$ с синдромом Ангельмана не обнаруживают ни делеции, ни однородительской дисомии. В этих случаях болезнь может иметь семейное происхождение. Эти два синдрома являются примером геномного импринтинга у человека. Генные локусы этих синдромов, следовательно, являются объектами геномного импринтинга. Импринтинговые локусы в этом участке затрагивают большое число генов и, по-видимому, контролируются общим центром импринтинга, расположенном в этом районе. Мутации в центре импринтинга могут передаваться половыми клетками одного из родителей.

Унипарентальная или однородительская дисомия является феноменом, определяемым присутствием двух гомологичных хромосом (или хромосомных сегментов), унаследованных только от одного родителя и отсутствием соответствующей хромосомы (или сегмента), унаследованных от другого родителя. Различают два типа унипарентальной дисомии: изодисомия и гетеродисомия. Термин изодисомии относится к наличию двух копий одной и той же родительской хромосомы; гетеродисомия означает, что каждая из двух гомологичных хромосом передалась от одного родителя. Однородительская дисомия может являться причиной различных заболеваний у человека, включая мультифакторные болезни, связанные с нарушениями психики.

Повторяющиеся последовательности ДНК являются относительно нестабильными элементами генома человека. Для медицинской генетики, изучающей различные генетические феномены, связанные с нарушениями психики, особый интерес представляют тринуклеотидные повторы - тандемно повторяющиеся 
элементы, дискретной единицей которых является последовательность, состоящая из 3-х нуклеотидов. Несмотря на то, что заболевания, причиной которых является экспансия (увеличение) тринуклеотидных повторов, вызваны мутационными изменениями последовательности ДНК, многие из них принято рассматривать в рамках эпигенетики. Это связано с тем, что некоторые тринуклеотидные повторы имеют в своей структуре цитозин и гуанин, образующие ЦГ последовательности, цитозин которых в условиях экспансии метилируется. Наиболее ярким примером такого заболевания, имеющим исключительное значение для медицинской генетики, педиатрии и психиатрии, является синдром умственной отсталости, сцепленный с ломкой хромосомой $X$ или FRAXА. FRAХА представляет собой самую частую генетическую форму, связанную с умственной отсталостью и экспансией тринуклеотидных повторов. Это заболевание связано с увеличением нестабильных ЦГГ-повторов в гене FMR1 (Fragile $X$ mental retardation 1 ). Считается, что больные FRAXA характеризуются наличием более 200 тринуклеотидных ЦГповторов. В результате экспансии ЦГГ-повторы также как и ЦГ динуклеотиды, расположенные далее по длине последовательности, метилируются, что приводит к отсутствию экспрессии гена $F M R 1$. Отсутствие продукта транскрипции гена $F M R 1$ - белка FMRP приводит к умственной отсталости в сочетании с различными когнитивными отклонениями. Из фенотипических проявлений синдрома FRAXA необходимо отметить умеренную или тяжёлую умственную отсталость (IQ = 30-55), гиперактивность, гиперкинез, эмоциональную нестабильность, признаки аутизма, большие оттопыренные ушные раковины, макроорхидизм, а также неадекватные движения рук (в $60 \%$ случаев); уменьшенный ответный глазной контакт (в $90 \%$ случаев); характерные изменения речи (быстрое повторение целых фраз, окончаний, звуков, бормотание); у 50 \% больных девочек наблюдается умственная отсталость средней тяжести, приводящая к когнитивным отклонениям; макроцефалия (в раннем детстве). В ряде случаев наблюдается внезапная смерть. Психопатологические отклонения, в основном, присутствующие у мальчиков, характеризуются 
выраженным полиморфизмом: от разной степени умственной отсталости до ранней злокачественной детской шизофрении со спонтанно возникающими тревожно-депрессивными состояниями и бредоподобным фантазированием. У нормальных индивидуумов число повторов варьирует от 6 до 52. Известно также, так называемое, «премутационное состояние», которое характеризуется увеличением ЦГГ-повторов от 54 до 200. Частота носителей премутации в общей популяции оценивается как 1:250 женщин и 1:800 мужчин. У $30 \%$ мужчин с премутацией в гене FMR1 наблюдаются характерные фенотипические отклонения - синдром FXTAS (fragile $\mathrm{X}$ tremor and ataxia syndrome - синдром тремора и атаксии, сцепленный с ломкой хромосомой X). Кроме тремора и атаксии, у этих больных наблюдаются также социопатия, уменьшенный ответный глазной контакт, депрессия, когнитивные расстройства; отмечаются гиперактивность с дефицитом внимания, легкая умственная отсталость и аутистические проявления. Среди женщин с премутацией в гене FMR1 частота фенотипических отклонений пока не выяснена. Это может быть связано с компенсирующим эффектом присутствия второй хромосомы Х в женском кариотипе. Однако, известно, что у женщин с премутацией в 16-24\% случаев наблюдается повышенная частота рекуррентных спонтанных абортов, причина которых в настоящее время неизвестна.

\section{ГЛава 3. ЦИТОГЕНЕТИЧЕСКИЕ ОСНОВЫ НАС ДЕДСТВЕННОСТИ}

В этой главе изложены данные современной науки о цитогенетической основе наследственности, о преобразовании хромосом человека в процессе деления клетки (митоза и мейоза), рассмотрены различные вариации генома человека (хромосомные мутации) в виде структурных и численных аномалий хромосом, ведущих к определённому фенотипу, описаны гетерохроматиновые и эухроматиновые районы (участки хромосом), типы хромосомной ДНК. 


\section{1. Геном человека и структурная организация хромосом}

Геном иеловека - термин, используемый при описании всей генетической информации, закодированной в виде ДНК клеток человека. Клетка человека имеет два генома: сложный ядерный геном (хромосомная ДНК), содержащий более 99,9995\% всей генетической информации, и простой митохондриальный геном, в составе которого находится менее $0,0005 \%$ ДНК. Ядерный геном распределён между 24-мя различными двуспиральными молекулами ДНК, которые в комплексе с различными гистоновыми и негистоновыми белками формируют хромосомы человека. С молекулярной точки зрения каждая хромосома клетки является сложно организованной структурой. Диплоидная клетка человека с интерфазным ядром при диаметре 5-10 мкм содержит около двух метров последовательностей молекул ДНК, которые образуют 23 пары хромосом. Гаплоидный геном человека, который характеризует половые клетки с хромосомами Х или Ү, включает 23 различные хромосомы - 22 аутосомы и одну половую хромосому (гоносому) в зависимости от пола: X - женский или $\mathrm{Y}-$ мужской пол. Индивидуальные хромосомы, как было сказано выше, различаются своими морфологическими характеристиками. В среднем, хромосома человека содержит около 130 млн пн, однако содержание ДНК в разных хромосомах варьирует от 40 до 260 млн пн.

Как уже сказано выше, данные о структуре, размерах и количестве митотических хромосом в клеточном ядре определяются как кариотип. Морфологическое строение хромосом на всех уровнях организации (молекулярном, микроскопическом и субмикроскопическом) определяется упаковкой нитей ДНК, организующих хромосому. На микроскопическом уровне нити ДНК формируют спирализованные хромонемы митотических хромосом. Упаковка хромонем по длине хромосом неравномерна. В них закономерно дифференцируются участки с резко выраженной и резко сниженной степенью спирализации хромонем. Последние формируют хромосомные перетяжки. Важным элементом структуры хромосом является первичная перетяжка, в участке 
которой расположена центромера. Она делит хромосому на два плеча - короткое (p) и длинное $(q)$.

Структура хромосом претерпевает значительные изменения в ходе клеточного деления (клеточного цикла) и, следовательно, не является постоянной. Хромосомы интерфазных ядер (интерфазные хромосомы) в отличие от метафазных хромосом (см раздел, посвященный делению клетки) представляют собой более расправленные и диффузные клеточные структуры. Интерфазные хромосомы содержат одну хроматиду, в составе которой имеется одна двуспиральная молекула ДНК, в то время как метафазные хромосомы образованы двумя хроматидами и двумя молекулами ДНК. Хромосома, как функционирующая клеточная органелла, должна содержать минимум три типа последовательностей ДНК, формирующих её структурные компоненты: центромеру, теломеры и участок начала репликации ДНК.

Индивидуальные хромосомы содержат одну протяжённую двуспиральную молекулу ДНК диаметром 2 нм, которая претерпевает несколько уровней упаковки, формируя хроматин или ДНК-белковый комплекс (дезоксирибонуклеопротеид - ДНП). Элементарной дискретной единицей упаковки хроматина является нуклеосома. Каждая нуклеосома имеет вид глобулы и состоит из четырех пар гистоновых белков Н2А, Н2B, Н3 и Н4, содержащих по 102-135 аминокислотных остатков. Вокруг гистоновой глобулы диаметром 10 нм (октамера) располагается молекула двуспиральной ДНК длиной 146 пн (или 68 нм), образуя виток в 1,75 оборота. Соседние нуклеосомы соединяются так называемой «спейсерной» ДНК длиной около 20 нм, образуя структуры в виде «бус на нитке». На следующем этапе компактизации 10-нанометровые нуклеосомы образуют фибриллы хроматина диаметром 30 нм (в каждом витке примерно 6 нуклеосом), которые образуют большие петли. На стадии метафазы степень компактизации достигает 1 на 10000 от первоначальной длины хромосомной ДНК. Петли 30-нанометровых фибрилл хроматина содержат 20-100 тысяч пн. ДНК на каждой петле прикрепляется к осевой структуре хромосомы (рис. 4). Осевые компоненты метафазной хромосомы состоят из негистоновых белков. 


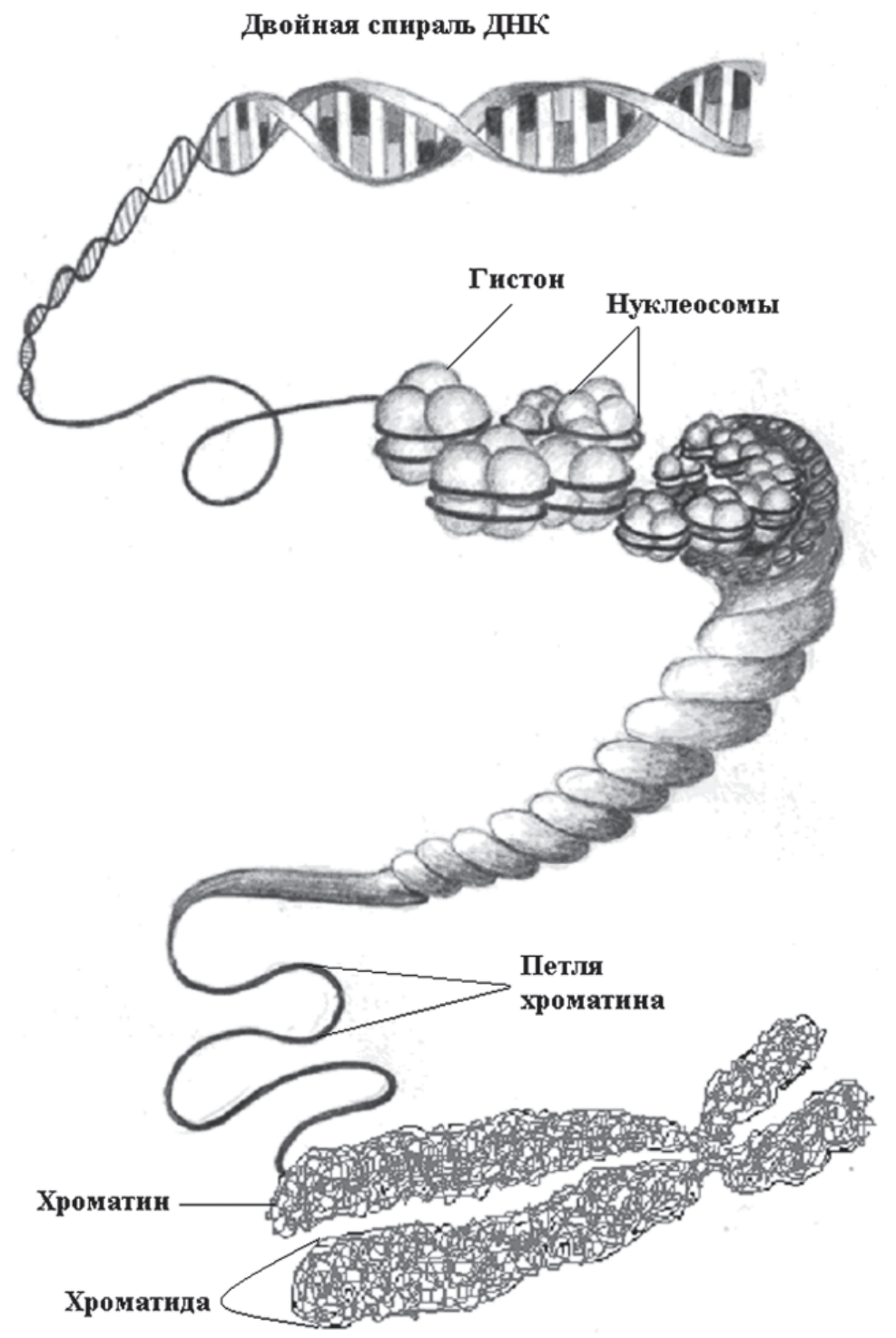

Рис. 4. Организация ДНК 
Как уже отмечалось, одним из структурных элементов хромосомы является центромера - место присоединения кинетохоров (макромолекулярных структур на белковой основе, участвующих в процессе расхождения хромосом при митотическом делении клетки), и слипания сестринских хроматид. Они также регулируют присоединение хромосом к веретену деления и направляют движение хромосом в ходе мейотического и митотического деления клетки. Хромосомы без центромеры (ацентрические фрагменты) не могут присоединяться к нитям веретена деления и теряются в ходе клеточного деления. У человека центромеры содержат особые типы повторяющихся ДНК, а также специфические «центромерные» белки, обеспечивающие сегрегацию хромосом в ходе митотического и мейотического деления клеток. В зависимости от положения центромеры в хромосоме, как уже сказано выше, она может быть метацентрической, субметацентрической и акроцентрической. В акроцентрических хромосомах довольно часто на коротких плечах видны небольшого размера хроматические тельца, так называемые спутники, и спутничные нити (рис. 5). Они содержат ядрышковый организатор - значимую структуру генома человека. Плечи некоторых хромосом человека содержат вторичные перетяжки.
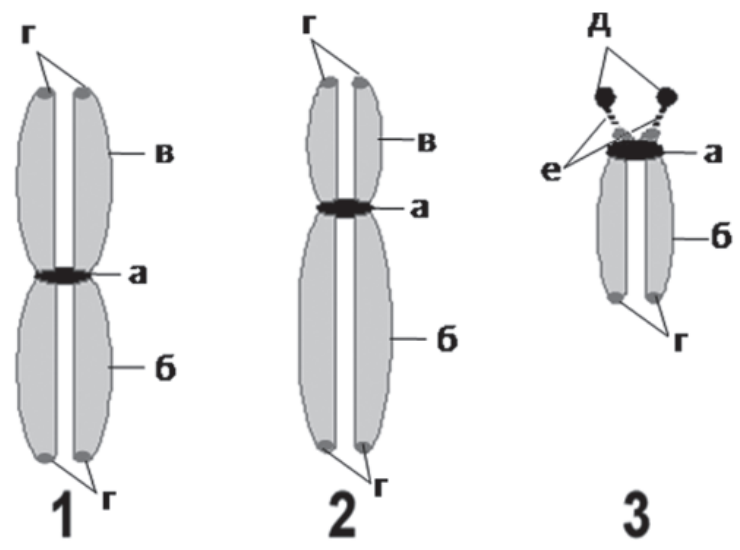

Рис. 5. Схематическое изображение метафазных хромосом:

1 - метацентрическая хромосома; 2 - субметацентрическая хромосома; 3 - акроцентрическая хромосома.

Видны: а - центромеры; б - длинные плечи (q); в - короткие плечи (p); г - теломерные участки; д - спутники; е - спутничные нити 
Другими структурными элементами хромосом являются $\boldsymbol{m} \boldsymbol{e}$ ломеры. Это специализированные структуры, содержащие особые типы ДНК и белки, которые образуют концевые участки хромосом. Теломеры выполняют несколько функций:

1) поддержание структурной целостности хромосомы;

2) обеспечение полной репликации концевых участков хромосомы;

3) поддержание организации хромосом в интерфазном ядре.

Теломеры хромосом человека представляют собой повторы нуклеотидной последовательности ТТАГГГ, общий размер которой варьирует от 3 до 20 тысяч пн. Стабильность теломер поддерживается с помощью фермента теломеразы, нарушение функциональной активности которой приводит к нарушению структуры хромосом и, как следствие, к клеточной гибели. Укорочение последовательностей теломер, которому противодействует теломераза, связано с процессами старения и малигнизации.

ДНК хромосом реплицируется в ходе периода синтеза ДНК клеточного цикла. Каждая хромосома содержит множество элементарных единиц репликации - репликонов, представляющих собой участки автономной репликации. Каждый репликон имеет одну точку инициации репликации, с которой начинается двунаправленный синтез ДНК (см предыдущий раздел, посвященный синтезу ДНК). Размеры репликонов могут различаться друг от друга. Репликоны у человека могут иметь большие размеры, достигая более чем 1 млн пн.

\section{2. Гетерохроматин и эухроматин}

Каждая хромосома человека дифференцирована на два типа различных участков: так называемые, эухроматиновые и гетерохроматиновые районы хромосом. Существует два основных типа хроматина: гетерохроматин и эухроматин. Данная классификация основана на ранних изучениях свойств хроматина хромосом человека в интерфазных ядрах, содержащих деконденсированный хроматин (эухроматин), распределенный диффузно и слабо окрашиваемый при использовании специфических гистологических красителей, 
а также конденсированные темно-окрашенные блоки хроматина (гетерохроматин). В эухроматиновых участках хромосом локализовано подавляющее большинство генов, в то время как гетерохроматин содержит мало генов, которые, по-видимому, обычно не активны. Выделяют два основных типа гетерохроматина: конститутивный и факультативный. Конститутивный гетерохроматин, который практически на протяжении всего клеточного цикла конденсирован, генетически не активен. Вероятно, последовательности ДНК, из которых состоит конститутивный гетерохроматин, практически не содержат генов. Этот тип гетерохроматина сформирован особыми классами высокоповторяющихся (сателлитных) последовательностей ДНК и расположен в участках центромер всех хромосом, а также в некоторых других ее участках. Факультативный гетерохроматин представляет собой инактивированные и конденсированные участки хромосом, которые могут обратимо переходить из эухроматинового в гетерохроматиновое состояние в зависимости от типа клетки, стадии клеточного цикла или особенности одной из гомологичных хромосом. Как правило, этот термин применяется для описания процесса инактивации хромосомы $\boldsymbol{X}$ в клетках, которые содержат две и более хромосомы X.

\section{3. Типы хромосомной ДНК}

Вся нуклеотидная последовательность ДНК в геноме человека полностью установлена. Однако это утверждение относится лишь к эухроматиновым районам хромосом (около $90 \%$ генома), в то время как определить полностью последовательности ДНК гетерохроматина пока не удалось. В состав генома человека входят уникальные последовательности ДНК, кодирующие отдельные гены, и многочисленные семейства повторяющихся последовательностей ДНК, которые являются транскрипционно неактивными. Повторяющиеся ДНК имеют два основных типа организации в хромосомной ДНК: тандемно повторяющиеся (ИЛи сателлитные) и диспергированные по геному последовательности. 
К тандемно повторяющимся последовательностям относятся три основных типа ДНК: сателлитные, минисателлитные и микросателлитные ДНК. Сателлитная ДНК человека образована большими участками тандемно повторяющихся последовательностей различной сложности. Повторы ДНК этого типа не транскрибируются и расположены преимущественно в участках гетерохроматина генома - в центромерных участках всех хромосом и районах вторичных перетяжек.

Минисателлитные ДНК состоят из среднего размера (20-70 пн) тандемно повторяющихся единиц ДНК (до 1000 повторов длиной до 20 тысяч пн), диспергированных среди различных участков геномной ДНК. Минисателлиты обычно не транскрибируются. К этим повторам относятся так называемые гипервариабельные (высокополиморфные) минисателлитные ДНК, находящие применение при генетической идентификации личности (ДНК фингерпринт).

Микросателлитые ДНК представлены короткими тандемными повторами (1-4 пн), диспергированными по геному. Распространенные мононуклеотидные повторы (А или Т) образуют до 0,3\% генома человека. Динуклеотидные повторы формируют до 0,5\% генома. Тринуклеотидные или четырехнуклеотидные повторы относительно редки, но очень часто высокополиморфны и находят применение в разработке полиморфных маркеров для молекулярно-генетических исследований и диагностики.

Существует два основных класса диспергированных ДНК повторов, которые различаются по длине: короткие и длинные ДНК повторы. Короткие диспергированные ДНК повторы (SINEs) относятся к так называемому семейству Alu повторов. Длина Alu повторов составляет около 280 пн. Эти повторы встречаются примерно через каждые 3 тысячи пн, число которых составляет до одного миллиона на геном. Длинные диспергированные ДНК nовторы (LINEs) относятся к так называемому семейству L1 или Kрn повторов. Усреднённая последовательность L1 повтора имеет длину 6,1 тысяч пн. Число этих повторов составляет более 100000 на геном. 
Распределение уникальных и повторяющихся последовательностей ДНК в хромосомах человека неравномерно. Эухроматиновые районы хромосом содержат перемежающиеся участки, обогащённые короткими или длинными диспергированными повторами (Alu и L1). Гетерохроматиновые районы хромосом содержат, в основном, сателлитные ДНК повторы.

\section{4. Деление клетки}

Все клетки человека проходят через цикл деления (клеточный цикл). Известны два типа деления клетки: митотческое и мейотическое, которые представлены на рисунках 6 и 7. Митоз - деление клетки, за счет которого достигается воспроизведение соматических клеток в организме. Мейоз - деление клеток, в ходе которого получаются клетки с редуцированным гаплоидным (n) набором хромосом (половые клетки). Среднее время клеточного цикла у млекопитающих составляет 17-18 часов. Клеточный цикл разделен на четыре основных стадии: $\boldsymbol{G} \boldsymbol{1}, \boldsymbol{S}$ (фаза синтеза ДНК), $\boldsymbol{G 2}$ и митоз (M). Первые три фазы представляют собой интерфазный период или интерфазу. Клетки, которые не делятся, находятся на стадии покоя $\boldsymbol{G} \boldsymbol{0}$.

Во время стадии G1 (примерно 9 часов) хромосомы имеют вид одиночных хроматид, клетка метаболически активна и в ней происходит синтез белков. Если клетка, находящаяся на G1 стадии, не подвергается последующему делению, то это состояние соответствует G0. Фаза синтеза (или S фаза) длится около 5 часов и характеризуется процессом репликации хромосомной ДНК. На этой стадии хромосомы состоят из двух идентичных сестринских хроматид. G2 стадия длится примерно 3 часа. Во время этой стадии клетка готовится к процессу деления. Завершение G2 соответствует концу интерфазы. Митоз длится не более 1-2 часов и является процессом образования двух генетически идентичных дочерних клеток. В свою очередь, митоз также делится на 4 стадии: профаза, метафаза, анафаза и телофаза (рис. 6). 


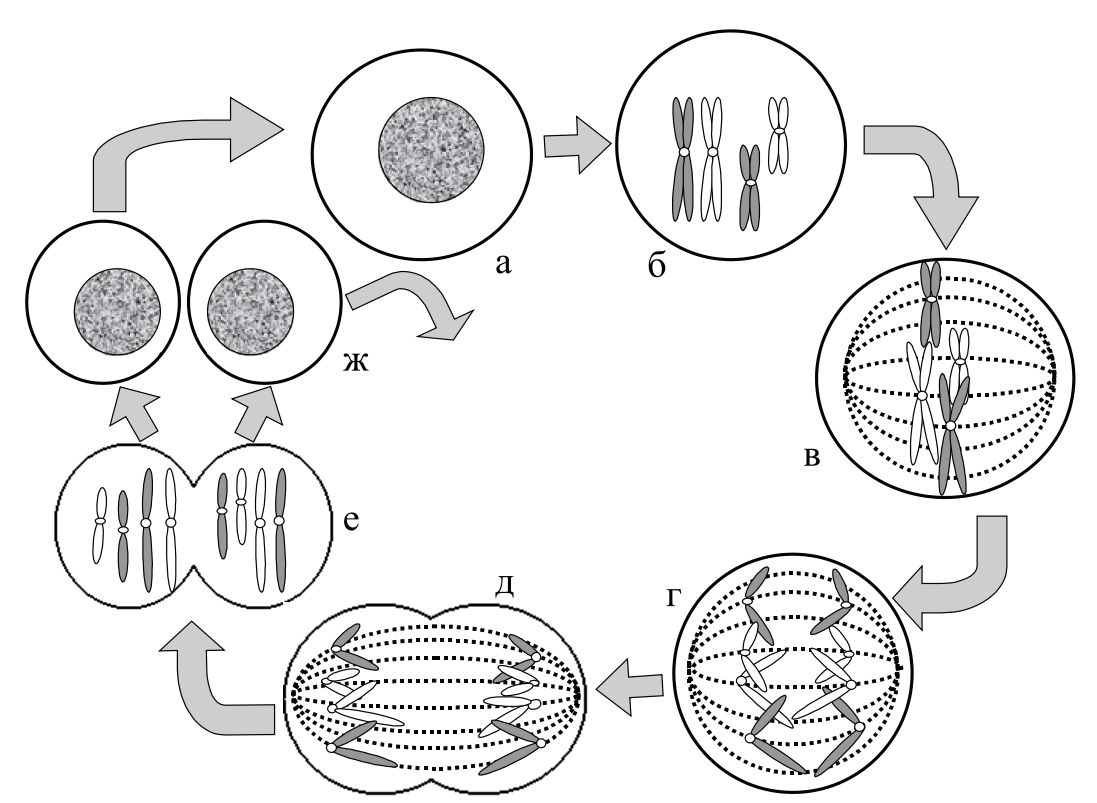

Рис. 6. Митоз. Схематическое изображение двух пар хромосом во время митоза: а - интерфаза; б - профаза; в - метафаза; г - анафаза; д - телофаза; е - цитокинез; ж - интерфазы разделившихся клеток

Профаза - стадия, во время которой происходит постепенная конденсация (уплотнение) и спирализация хромосом, в результате чего, они имеют вид дискретных структур. Во время профазы образуется веретено деления (двуполюсное веретено, состоящее из пучков микротрубочек, которые тянутся от одного полюса к другому).

Метафаза - стадия, характеризующаяся тем, что полностью осуществляется присоединение хромосом к нитям веретена, и хромосомы собираются в экваториальной плоскости клетки, находящейся на одинаковом расстоянии от обоих полюсов веретена. На этой стадии хромосомы достигают максимальной конденсации.

Цитогенетики выделяют начало метафазы как прометафазу, на которой довольно часто проводят лабораторные исследования. Прометафаза - короткий промежуточный период между профазой и метафазой, в ходе которой исчезает ядерная мембрана 
и появляются нити веретена деления, к которым с помощью кинетохоров присоединяются хромосомы.

Анафаза - стадия разделения сестринских хроматид и их расхождения к противоположным полюсам веретена.

Телофаза - последняя стадия митоза. Она начинается, когда все сестринские хроматиды доходят до полюсов веретена. В ходе данной фазы митоза происходит восстановление клеточного ядра и внутриядерных структур. За ней, как правило, следует цитокинез - разделение двуядерной клетки на две с одним ядром в каждой (рис. 6).

Мейоз - деление клеток, в ходе которого получаются клетки с редуцированным гаплоидным набором хромосом (половые клетки). Данный процесс включает в себя две фазы клеточного деления: мейоз 1 и мейоз 2. В ходе мейоза происходит редукция диплоидного хромосомного набора (2n) до гаплоидного (n).

Мейоз 1, в свою очередь также делится на несколько стадий: профаза I, метафаза I, анафаза I и телофаза I (рис. 7). Профаза I является комплексной стадией, которая, в свою очередь, делится на несколько этапов:

лептотена: 46 хромосом состоят из 2-х хроматид и начинают коденсироваться; эта стадия характеризует начало мейоза;

зиготена: гомологичные хромосомы спариваются своими участками - этот этап деления называется синапсом; в результате образуется тройственная структура - синаптонемальный комплекс;

naxumeна: стадия завершения синапса, спаренные гомологи, состоящие из 4-х хроматид, формируют бивалент; во время этой стадии происходит кроссинговер - обмен последовательностями ДНК хромосом между несестринскими хроматидами бивалентов. Результатом этого процесса является рекомбинация генетического материала между гомологичными хромосомами, создающая новые комбинации генов в дочерних клетках;

диплотена: на этой стадии хромосомы отталкиваются друг от друга до тех пор, пока гомологи не будут соединены только участками, подверженными кроссинговеру. Такие участки называются хиазмами;

диакинез: хромосомы претерпевают наибольшее сжатие во время этой последней стадии профазы I. 


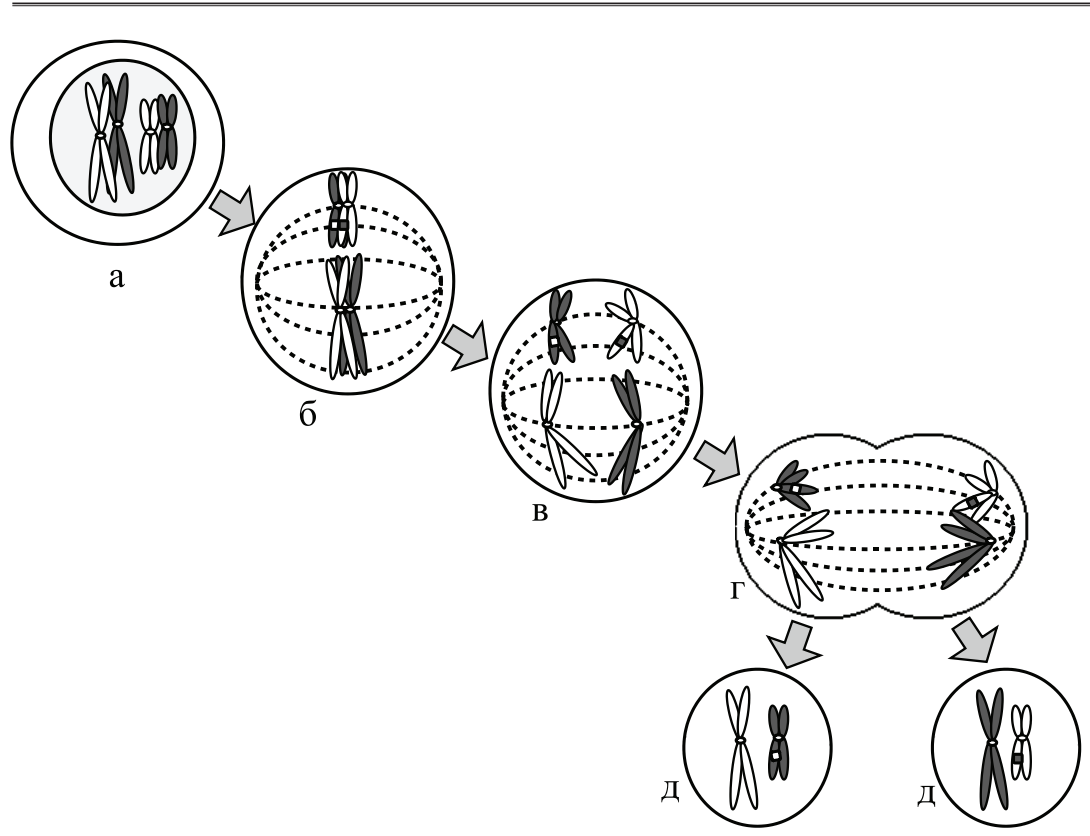

Рис. 7. Мейоз I. Схематическое изображение двух пар хромосом во время мейоза I:

a - профаза I; б - метафаза I; в - анафаза I; г - телофаза I;

д - клетки, образующиеся в результате первого мейоза

Метафаза I характеризуется исчезновением ядерной мембраны и образованием мейотического веретена деления. Биваленты выравниваются по экваториальной плоскости клетки и их центромеры случайным образом ориентируются к противоположным полюсам. Во время анафазы I биваленты разделяются и расходятся к противоположным полюсам. В ходе телофазы I каждая хромосома из двух гаплоидных наборов достигает противоположных полюсов, и образуются две дочерние клетки, в каждой из которых по 23 хромосомы, состоящие из $2-$ х хроматид.

Мейоз 2 практически идентичен митотическому делению за исключением того, что в данном случае делящиеся клетки имеют гаплоидный хромосомный набор. Хромосомы выравниваются по экваториальной плоскости клетки на стадии метафазы II, хроматиды 
разделяются и расходятся к противоположным полюсам на стадии анафазы II, цитокинез происходит на стадии телофазы II. В результате митотического деления (мейоза 1 и 2), как правило, образуются 4 дочерние клетки с гаплоидным набором хромосом, каждая из которых генетически отличается друг от друга за счет процесса кроссинговера и случайного расхождения гомологичных хромосом.

\section{5. Вариации генома человека: хромосомные мутации}

Хромосомные (геномные) мутащии (аномалии) связаны либо с различными структурными перестройками хромосом, либо с изменением их числа (n). Численные изменения в наборе хромосом (кариотипе) могут быть двух типов: полиплоидии - умножение полного хромосомного набора (3n, 4n и т. д.) или генома, кратное гаплоидному числу хромосом; анеуплоидии - увеличение или уменьшение числа хромосом в наборе, некратное гаплоидному. Эти количественные изменения кариотипа обусловлены, как правило, нарушениями мейоза или митоза. Численные хромосомные аномалии в виде анеуплоидии делятся на моносомию (потерю хромосомы или её части - частичная моносомия) и трисомию или полисомию (приобретение одной/нескольких хромосом или её части - частичная трисомия). Данные изменения кариотипа связаны с комплексом врождённых пороков развития и, как правило, с заболеваниями, сопровождающимися умственной отсталостью или тяжелыми психическими расстройствами. В настоящее время описаны случаи изменений хромосомного набора с участием половых хромосом и некоторых аутосом при шизофрении и аутизме. Например, до 5-15\% детей с аутистическими расстройствами имеют хромосомные аномалии. Это позволяет рассматривать хромосомный дисбаланс клеток организма в качестве одной из возможных причин отдельных случаев нервных и психических болезней.

Структурные изменения могут затрагивать всю хромосому, а также сопровождаться изменением количества генетического материала в ядре или его перемещением. Сбалансированные хромосомные аномалии представляют собой перестройки, за счет которых выявляется кариотип с измененным набором расположения генов в пределах хромосом или между хромосомами, который 
отличается от нормального кариотипа. В большинстве случаев носители сбалансированных хромосомных аномалий фенотипически нормальны, но для их потомства возникает большой риск иметь несбалансированный кариотип. Следует отметить, что в отдельных случаях носители сбалансированного кариотипа могут иметь различные врождённые пороки и/или микроаномалии, а также нарушения нервного и психического развития. Если при структурных хромосомных мутациях наблюдается потеря или приобретение генетического материала, то они являются несбалансированными хромосомными аномалиями.

Цитогенетически структурные хромосомные перестройки классифицируют по принципу линейной последовательности расположения генов: делеции (потеря хромосомных участков), дупликации (удвоение хромосомных участков), инверсии (перевертывание на $180^{\circ}$ относительно нормальной последовательности хромосомных участков), инсерции (вставки хромосомных участков) и транслокации (изменение расположения хромосомных участков). В последнее время в литературе хромосомные микроаномалии и перестройки могут обозначаться, как геномные.

Изменения генома (хромосом), приводящие к редким заболеваниям, могут включать как крупные микроскопически видимые перестройки (более 5 млн пн), так и вариации числа копий последовательностей ДНК (CNV) и однонуклеотидные полиморфные изменения последовательности ДНК (SNP). Как уже было сказано выше, в настоящее время для определения причины заболевания на геномном уровне используются различные технологии, наиболее распространенными из которых являются полногеномные методы, в частности, молекулярное кариотипирование (arrayCGH). Однако степень патогенности выявленных вариаций генома можно установить только при помощи использования инновационных биоинформатических технологий. Большой массив информации, собранный на интернет-ресурсах, позволяет уточнить функциональные особенности (онтологию) как отдельного гена, так и целой генной сети за счёт анализа последовательности кодируемого белка и моделирования молекулярных процессов, инициированных геномным изменением. 
Таким образом, с хромосомными болезнями связаны аномалии микроскопически видимых численных или структурных нарушений хромосом, геномные же болезни связаны как с микроаномалиям хромосом, так и с вариациями числа копий последовательностей ДНК (CNV). С внедрением в клиническую практику современных высокоразрешающих молекулярных методов исследования генома появилась возможность выявлять вариации генома размером от 100 пн, мозаицизм низкого уровня и участки потери гетерозиготности. Размеры перестроек могут варьировать от тысячи до нескольких миллионов пн. При «крупных» перестройках в генонасыщенных участках может быть охвачено от нескольких десятков до нескольких сотен генов. В случае если перестройка небольшого размера и затрагивает область внутри одного или нескольких генов, её называют интрагенной. Как и в случае других типов генетических мутаций, некоторые CNV передаются по наследству, но большинство патогенных аномалий возникают de novo. Как было отмечено выше, структурные вариации генома можно разделить на рекуррентные (часто встречающиеся в популяции, предположительно непатогенные) и нерекуррентные (редко встречающиеся перестройки). Хотя последствия большинства CNV остаются неизвестными, появляется всё больше доказательств того, что генетические нарушения при наиболее распространённых психических и неврологических нарушениях включают в себя различные типы как часто встречающихся, так и редких генетических вариаций. Отдельное внимание стоит уделить биоинформатическому анализу (см ниже), который используется для интерпретации данных, полученных при молекулярном кариотипировании. С использованием данного подхода к анализу полученных молекулярно-цитогенетических результатов можно проводить приоритизацию генов-кандидатов и процессов, лежащих в основе развития патологии.

Большое значение имеет изучение хромосомных мутаций под действием факторов внешней среды. Показано, что хромосомы человека отличаются высокой чувствительностью к действию радиации и химических веществ, которые принято называть мутагенными факторами (мутагенами). При анализе воздействия этих факторов следует различать нарушения в соматических и половых клетках. Первые затрагивают непосредственно жизнедеятельность 
исследуемого организма, тогда как вторые проявляются в последующих поколениях. Мутации хромосом в зародышевых клетках ведут к образованию аберрантных гамет, в результате которых возможна гибель зигот, эмбрионов на ранних стадиях внутриутробного развития, а также рождение детей с специфическими хромосомными аномалиями, которые проявляются в виде определенной клинической картины или определенного фенотипа. Мутации хромосом в соматических клетках ведут к образованию неспецифичных хромосомных аномалий в виде хромосомных или хроматидных пробелов, разрывов, обменов в кариотипе, не ведущих к определенному фенотипу, характерному для конкретного наследственного заболевания. Подобные мутации не наследуются. Следует отметить, что при изучении такого рода воздействия мутагенных факторов представляется возможным оценить качественно и количественно действие ионизирующей радиации, химических веществ, вирусов, но полученные данные не могут быть перенесены на половые клетки, где результатом действия являются специфические хромосомные аномалии, влияющие на фенотип.

Хромосомные аномалии могут проявляться в так называемых мозаичных формах, к которым приводит неправильное деление клеток на различных стадиях эмбрионального и постнатального развития. Это позволяет разделить хромосомные аномалии на мозаичные и регулярные (аномальный кариотип наблюдается во всех клетках организма). Хромосомный мозаицизм представляет собой наличие нескольких популяций клеток с различным друг от друга хромосомным набором. Как правило, при мозаичных формах хромосомных аномалий наблюдают отсутствие отдельных клинических признаков определенного хромосомного синдрома и более легкое течение заболевания, но некоторые симптомы практически всегда присутствуют. Мозаичные структурные хромосомные аномалии наблюдаются достаточно редко, поэтому, когда речь идет о мозаичных хромосомных аномалиях, имеются в виду, в основном, численные аномалии, мозаичные формы которых имеют достаточно высокую популяционную частоту. Следует также отметить феномен тканеспецифического хромосомного мозаицизма, когда клетки с аномальным хромосомным набором присутствуют только в определенной ткани организма. 


\section{Гдава 4. СЕМИОТИКА ГЕНЕТИЧЕСКИ ОБУСЯОВ ЯЕННЫХ БОЯЕЗНЕЙ}

Семиотика наследственных болезней - раздел медицинской генетики, который изучает признаки (симптомы) генетических заболеваний, включая в себя следующие направления: особенности клинических проявлений наследственных заболеваний и принципы их клинической диагностики; анализ данных функциональных и лабораторных (цитогенетических, молекулярно-цитогенетических, молекулярно-генетических и др.) методов исследования. Возможность клинической диагностики генетически детерминированных заболеваний в значительной степени определяется уровнем знания врачом их семиотики. Характерной чертой клинического проявления наследственной патологии, которую надо учитывать при верификации диагноза, являются множественные поражения систем организма. В основе множественного характера поражения лежит плейотропность действия генов. Это действие генов связано с явлением «плейотропия» - явление, при котором один ген обуславливает несколько признаков. Возможны случаи, когда при плейотропии определённый ген по отношению к одному признаку является доминирующим, а по отношению к другому - рецессивным. Отличительной особенностью наследственных заболеваний, имеющей значение при проведении диагностических мероприятий, являются их генетическая гетерогенность и клинический полиморфизм. Понимание генетических механизмов, определяющих вариабельность семиотики наследственно детерминированных заболеваний, даёт возможность не только осуществлять их полноценную клиническую диагностику, но и проводить эффективную лечебную коррекцию данной патологии.

\section{1. Особенности кдинических проявлений наследственных бодезний}

Семейный характер заболевания. Повторные случаи заболевания в семье указывают на его возможную генетическую природу. 
Однако единственный случай заболевания в родословной не исключает его наследственной этиологии, поскольку может быть результатом новой (спорадической) мутации или гетерозиготности обоих родителей по рецессивной мутации.

Прогредиентное течение - это прогрессирующий характер течения наследственного заболевания. Например, нейродегенеративные заболевания проявляются в виде потери ребёнком ранее приобретенных навыков, приводя впоследствии к развитию тяжёлого поражения ЦНС и гибели больного.

Редко встречающиеся специфические симптомы или их сочетание у больного дают основание предполагать наследственную природу заболевания. Например, голубые склеры наблюдаются у больных с несовершенным костеобразованием, грубые черты лица типичны для некоторых болезней накопления, звездчатая радужная оболочка глаз - признак синдрома Вильямса.

Врождённый характер заболевания. Если ребёнок рождается с патологическими симптомами, говорят о врождённом характере болезни. Все хромосомные синдромы формируются внутриутробно и могут быть выявлены при рождении, а в некоторых случаях - при ультразвуковом исследовании плода. Тем не менее, врождённость патологических признаков не всегда свидетельствует о наследственной природе заболевания. Примерами врождённых, но не наследственных болезней, являются эмбриофетопатии: талидомидная, алкогольная, вызванная вирусом краснухи и др.

Множественное поражение систем органов. Множественное поражение позволяет предполагать наследственную причину заболевания, поскольку большинство мутаций в генах, вызывающих наследственные болезни, даёт плейотропный эффект (см выше). Например, при мутациях гена TSC1, связанных с развитием туберозного склероза, наблюдается ряд признаков - снижение интеллекта, эпилепсия, высыпания на лице в виде, так называемой, аденомы Прингля (представляет собой фиброзную ткань и кровеносные сосуды). 
Микроаномалии развития у больного.

МАР - это необычные морфологические черты, не нарушающие функции каких-либо органов. Они служат индикаторами нарушенного морфогенеза и могут представлять собой симптомы заболеваний. Тщательное описание МАР является одним из диагностических приемов при большинстве наследственных заболеваний. Свыше $40 \%$ известных наследственных синдромов не имеют цитогенетических, биохимических или иных маркеров и идентифицируются на основании фенотипа больного, включая комплекс МАР. Подробно МАР описаны в разделе «Принципы клинической диагностики наследственных болезней» (глава 4.2).

Манифестация заболевания в определенном возрасте. Многие наследственные болезни имеют характерный возраст манифестации (от рождения при хромосомных/геномных болезнях до пожилого возраста при болезни Альцгеймера). Так, возраст появления первых признаков фенилкетонурии 3-4 месяца, а миопатии Эрба-Рота - около 20 лет.

Этническая предрасположенность. Некоторые наследственные заболевания встречаются преимущественно у лиц определенных этнических групп. Серповидноклеточная анемия широко распространена в ряде африканских стран, в частности, в Гане. Тирозинемия часто встречается у франкоязычного населения Канады.

Устойчивость к терапии. Резистентность к наиболее распространенным методам лечения характерна для наследственных заболеваний. Например, при муковисцидозе респираторная вирусная инфекция приводит к развитию пневмонии, несмотря на лечение. К счастью, резистентность к терапии характерна не для всех наследственных болезней. В тех случаях, когда известен патогенез заболевания, возможна успешная терапевтическая коррекция (например, специфическая диетотерапия при фенилкетонурии и галактоземии, заместительная гормональная терапия при врождённом гипотиреозе).

Дополнительными признаками наследственной патологии являются следующие проявления, специфичные для определенных 
групп заболеваний: спонтанные аборты и мертворождения в семье характерны для хромосомных заболеваний; задержка физического развития типична для более чем 500 моногенных синдромов и для хромосомных аномалий; родственные браки характерны для заболеваний с аутосомно-рецессивным типом наследования; необычный запах мочи и пота - признак ряда метаболических болезней; отставание в психическом развитии является признаком большинства наследственных заболеваний; деменция - ведущий симптом нейродегенеративных заболеваний; нарушение толерантности к физической нагрузке - признак митохондриальных миопатий; увеличение печени и селезенки в сочетании с грубыми чертами лица типичны для болезней накопления.

\section{2. Принципы клинической диагностики наследственных болезней}

Диагностика наследственных заболеваний чрезвычайно сложна из-за их многочисленности (несколько тысяч нозологических форм) и низкой частоты (частота многих заболеваний составляет 1:200000 и более).

Термин синдром обычно применяют для обозначения совокупности воспроизводимых симптомов, имеющих общую этиологию. Однако в клинической генетике его используют для обозначения отдельных нозологических форм. Это связано с тем, что исторически многие из них были описаны как симптомокомплексы без понимания этиологии. Несмотря на то, что в дальнейшем стали известны генетические причины этих заболеваний, за ними традиционно сохранилось название «синдром». Таким образом, для наследственной патологии понятия «болезнь» и «синдром» равнозначны. Для обозначения некоторых нозологических форм употребляются оба термина (например, болезнь Дауна и синдром Дауна, болезнь Марфана и синдром Марфана).

Среди симптомов наследственных болезней редко встречаются патогномоничные. Чаще всего один и тот же признак встречается при различных заболеваниях. Так, катаракта и помутнение хрусталика наблюдаются при более чем 
30 наследственных заболеваниях, а умственная отсталость при сотнях нозологических форм. Поэтому, в клинической генетике значим синдромальный подход к диагностике, согласно которому только сочетание симптомов является специфичным для конкретного заболевания.

На основе данных об особенностях клинических проявлений наследственной патологии строится схема обследования больного. Важным методом с точки зрения генетики является антропометрия. Необходимо оценивать следующие антропометрические показатели: длину и массу тела больного, тип телосложения, соотношение длины конечностей и туловища, а также отдельных частей конечностей (например, плеча и предплечья), окружности груди и головы, соотношение продольного и поперечного размера черепа, длину стопы и кисти. Эти данные оцениваются по специально разработанным центильным таблицам, основные из которых представлены в Приложении. При многих наследственных заболеваниях антропометрические показатели выходят за пределы допустимых вариаций вследствие нарушения роста скелета, диспропорциональности развития его отдельных частей. Например, высокий рост, длинные верхние и нижние конечности, пальцы могут быть признаками синдрома Марфана. Уменьшение окружности головы и размеров стоп помогают в диагностике синдрома Ретта.

Очень важно выявить у больного врождённые аномалии развития, которые могут быть либо проявлением наследственной патологии, либо следствием тератогенного воздействия средовых факторов. Следует остановиться на различиях между следующими употребляемыми в литературе терминами: врождённые пороки развития, врождённые аномалии, микроаномалии развития.

Врождённый порок развития - это морфологический дефект органа или его части, или большой области тела, ведущий к нарушению функции органа (органов) либо социальной адаптации индивидуума. Врождённая аномалия (или дефект) - более общее понятие, это любая функциональная или структурная аномалия, вызванная либо генетическим заболеванием, либо средовым событием, предшествующим рождению. Врождённые пороки 
развития подробно рассмотрены ниже (см раздел «Врождённые аномалии и синдромы», глава 6).

Микроаномалии развития (МAP) - необычные морфологические черты, которые, в отличие от пороков развития, не сопровождаются нарушениями функции органа или системы.

Как было сказано выше, при обследовании больных необходимо обращать внимание на МАР. Последние встречаются также и у здоровых людей, но наличие нескольких МАР указывает на высокую вероятность наследственной патологии. В таблицах 3 и 4 представлен перечень наиболее значимых микроаномалий и способы определения некоторых из них.

Таблица 3

\section{Микроаномалии развития}

\begin{tabular}{|l|l|}
\hline \multicolumn{1}{|c|}{$\begin{array}{l}\text { МАР органов } \\
\text { или части тела }\end{array}$} & \multicolumn{1}{|c|}{ Клинические признаки } \\
\hline \multicolumn{1}{|c|}{$\begin{array}{l}\text { I. Лицевая } \\
\text { область } \\
\text { и остальная } \\
\text { часть черепа }\end{array}$} & $\begin{array}{l}\text { Лицо: плоское, круглое, треугольное, вытянутое, грубые } \\
\text { черты, плоский профиль. } \\
\text { Брови: сросшиеся (синофриз), кустистые. } \\
\text { Нос: короткий, клювовидный, загнутый, седловидная } \\
\text { переносица, широкая плоская переносица, плоские кры- } \\
\text { лья носа, открытые вперёд ноздри. } \\
\text { Фильтр: длинный, короткий, плоский, глубокий. } \\
\text { Волосы: торчащие, два завитка (две макушки). } \\
\text { Голова: брахицефалия, долихоцефалия, тригоноцефалия, } \\
\text { акроцефалия, выступающий или скошенный лоб, вы- } \\
\text { ступающий затылок, затылочная шпора (выступающая } \\
\text { затылочная кость), плоский затылок. }\end{array}$ \\
\hline $\begin{array}{l}\text { ІІ. Область } \\
\text { глазных щелей } \\
\text { и вокруг них }\end{array}$ & $\begin{array}{l}\text { Экзофтальм, косоглазие. } \\
\text { Веки: эпикант, телекант, птоз (малый), колобома век. } \\
\text { Глазные щели: узкие, короткие. } \\
\text { Разрез глазных щелей: монголоидный, антимонголоидный. } \\
\text { Расстояние между глазами: гипотелоризм, гипертелоризм. } \\
\text { Склеры: голубые, телеангиэтазии на склерах. } \\
\text { Радужная оболочка глаза: колобома, гетерохромия. } \\
\text { Ресницы: неправильный рост (например, двойной ряд ресниц). }\end{array}$ \\
\hline
\end{tabular}


Продолжение табл. 3

\begin{tabular}{|c|c|}
\hline 1 & 2 \\
\hline $\begin{array}{l}\text { III. Область } \\
\text { ротовой по- } \\
\text { лости и вокруг } \\
\text { нее }\end{array}$ & $\begin{array}{l}\text { Челюсти: прогения (выступающая нижняя че- } \\
\text { люсть), ретрогения (смещенная назад нижняя } \\
\text { челюсть), прогнатия (выступающая верхняя че- } \\
\text { люсть), макрогения (большая нижняя челюсть) } \\
\text { и микрогения (маленькая нижняя челюсть), микро- } \\
\text { гнатия (маленькая верхняя челюсть) и макрогнатия } \\
\text { (большая верхняя челюсть). } \\
\text { Подбородок: скошенный, выступающий. } \\
\text { Язык: исчерченность, макроглоссия и микроглос- } \\
\text { сия (увеличение и уменьшение языка), короткая } \\
\text { уздечка. } \\
\text { Губы: тонкие, толстые, с бороздами, с множествен- } \\
\text { ными уздечками. } \\
\text { Рот: макростомия (большой рот) и микростомия } \\
\text { (маленький рот). } \\
\text { Нёбо: плоское, высокое, арковидное, готическое, } \\
\text { раздвоение язычка. } \\
\text { Зубы: неправильное расположение, неправильная } \\
\text { форма, врождённый избыток или врождённое от- } \\
\text { сутствие одного или нескольких зубов, гипоплазия } \\
\text { эмали, диастема верхняя и нижняя (увеличенние } \\
\text { промежутка между первыми резцами), тремы (ши- } \\
\text { рокие промежутки между зубами). }\end{array}$ \\
\hline $\begin{array}{l}\text { IV. Ушные } \\
\text { раковины }\end{array}$ & $\begin{array}{l}\text { Асимметрия размера, большие, маленькие оттопы- } \\
\text { ренные, косо направленные, низко расположенные, } \\
\text { приросшая мочка, маленькая или отсутствующая } \\
\text { мочка, уплощенные ушные раковины, неполное раз- } \\
\text { витие завитка со сглаженным упрощенным рисунком, } \\
\text { отсутствие козелка, околоушные придатки, преаури- } \\
\text { кулярная фистула. }\end{array}$ \\
\hline $\begin{array}{l}\text { V. Верхние } \\
\text { конечности }\end{array}$ & $\begin{array}{l}\text { Длина пальцев: брахидактилия (короткие пальцы), } \\
\text { укорочение отдельных пальцев, арахнодактилия } \\
\text { (длинные «паучьи» пальцы). } \\
\text { Количество пальцев: полидактилия (дополнительные } \\
\text { пальцы), олигодактилия (уменьшение количества } \\
\text { пальцев). }\end{array}$ \\
\hline
\end{tabular}


И.Ю. Юров, С.Г. Ворсанова, В.Ю. Воинова, М.И. Чурносов, Ю.Б. Юров

Продолжение табл. 3

\begin{tabular}{|l|l|}
\hline 1 & \multicolumn{1}{|c|}{2} \\
\hline & $\begin{array}{l}\text { Форма пальцев: утолщение ногтевых фаланг, кону- } \\
\text { совидная форма. } \\
\text { Подвижность пальцев: камптодактилия (тугопод- } \\
\text { вижность межфаланговых суставов), сверхгибкость } \\
\text { (гиперэкстензия). } \\
\text { Мизинец: короткий, серповидный (клинодакти- } \\
\text { лия), дополнительные складки, отсутствие сгиба- } \\
\text { тельной складки либо одна складка. } \\
\text { Большой палец: широкий, трёхфаланговый, его } \\
\text { гипоплазия. } \\
\text { Ногт: удвоение ногтя большого пальца, гипопла- } \\
\text { зия ногтей. } \\
\text { Синдактилия (сросшиеся пальцы). Поперечная ла- } \\
\text { донная борозда (четырехпальцевая борозда). }\end{array}$ \\
\hline VI. Нижние \\
конечности & $\begin{array}{l}\text { Форма и длина: укороченные, удлинённые, вальгус- } \\
\text { ная деформация (Х-образные) или варусная дефор- } \\
\text { мация (О-образные). } \\
\text { Форма стопы: полая, стопа-качалка. } \\
\text { Пальцы стоп: синдактилия, асимметрия длины } \\
\text { пальцев, 3-й палец длиннее 2-го, глубокая борозда } \\
\text { между 1-м и 2-м пальцами, сандалевидная щель, } \\
\text { широкий большой палец, полидактилия, брахидак- } \\
\text { тилия. } \\
\text { Глубокая складка на стопе. }\end{array}$ \\
\hline $\begin{array}{l}\text { УІІ. Область } \\
\text { вища иуло- }\end{array}$ & $\begin{array}{l}\text { Шея: короткая, длинная, кривошея, крыловидные } \\
\text { складки, низкая линия роста волос на шее. } \\
\text { Груная клетка: воронкообразная, килевидная, } \\
\text { щитовидная. } \\
\text { Соски: гипертелоризм, резкая гипоплазия, распо- } \\
\text { ложение на разном уровне, полителия (добавочные } \\
\text { соски). } \\
\text { Пилонидальная ямка (втяжение кожи в виде ямки, } \\
\text { часто локализуется в области крестца). }\end{array}$ \\
\hline
\end{tabular}


Окончание табл. 3

\begin{tabular}{|l|l|}
\hline \multicolumn{1}{|c|}{1} & \multicolumn{1}{|c|}{2} \\
\hline $\begin{array}{l}\text { VIII. Половые } \\
\text { органы }\end{array}$ & Шалевидная мошонка, увеличенный клитор. \\
\hline $\begin{array}{l}\text { IX. Кожа, } \\
\text { е придатки } \\
\text { клетчатка }\end{array}$ & $\begin{array}{l}\text { Пятна на коже: гемангиомы, телеангиэтазии, } \\
\text { крупные невусы (пигментированные выступающие } \\
\text { участки кожи диаметром более 1 см), волосатый не- } \\
\text { вус, пигментация, депигментация. } \\
\text { Повышенная растяжимость кожи, «лишняя» кожа. } \\
\text { Волосы: сухие, редкие, шерстистые, седая прядь } \\
\text { надо лбом, «мыс вдовы», низкий рост волос на лбу, } \\
\text { гипертрихоз (избыточный рост волос), гирсутизм } \\
\text { (повышенное оволосение у девочек по мужскому } \\
\text { типу), алопеция (облысение тотальное, гнёздное). } \\
\text { Ногти: короткие, широкие, вогнутые, гипоплазия, } \\
\text { дистрофия ногтей, ногти в виде «часовых стекол». } \\
\text { Необычные ямки на лице и туловище, липомы, } \\
\text { фибромы. }\end{array}$ \\
\hline
\end{tabular}

МАР, часто исчезающие в течение первых 2 лет жизни следующие: плоская капиллярная гемангиома на лице и шее, неполное развитие завитка уха, гипоплазия ногтя большого пальца ноги, широкая переносица, эпикант.

Таблица 4

Способы определения некоторых микроаномалий

\begin{tabular}{|c|l|}
\hline \multicolumn{1}{|c|}{ МАР } & \multicolumn{1}{|c|}{ Способ определения } \\
\hline 1 & \multicolumn{1}{|c|}{2} \\
\hline $\begin{array}{l}\text { Плоский за- } \\
\text { тылок }\end{array}$ & $\begin{array}{l}\text { Определяется у больного в положении лежа на спине - } \\
\text { затылок, шея и спина располагаются на одном горизон- } \\
\text { тальном уровне. }\end{array}$ \\
\hline
\end{tabular}


И.Ю. Юров, С.Г. Ворсанова, В.Ю. Воинова, М.И. Чурносов, Ю.Б. Юров

Окончание табл. 4

\begin{tabular}{|c|c|}
\hline 1 & 2 \\
\hline $\begin{array}{l}\text { Гипер- и ги- } \\
\text { потелоризм } \\
\text { глазных щелей }\end{array}$ & $\begin{array}{l}\text { Определяется с помощью орбитального индекса } \\
\text { (Ио): отношение расстояния между внутренними } \\
\text { углами глазных щелей к окружности головы на } \\
\text { уровне глаз. } \\
\qquad \text { Ио }=a / b \times 100 \%, \\
\text { где } a-\text { расстояние между внутренними углами глазных } \\
\text { щелей; } \\
b-\text { окружность головы на уровне глаз. } \\
\text { Ио } \geq 7,5 \% \text { - гипертелоризм, Ио } \leq 5,2 \%-\text { гипотелоризм. }\end{array}$ \\
\hline Телекант & $\begin{array}{l}\text { Смещение внутренних углов глазных щелей латерально } \\
\text { при нормально расположенных глазницах. }\end{array}$ \\
\hline $\begin{array}{l}\text { Косое располо- } \\
\text { жение ушных } \\
\text { раковин }\end{array}$ & $\begin{array}{l}\text { Угол, образованный линиями, проходящими вдоль } \\
\text { ушной раковины и вертикалью, проходящей через } \\
\text { мочку, }>20^{\circ} .\end{array}$ \\
\hline $\begin{array}{l}\text { Асимметрия } \\
\text { ушных раковин }\end{array}$ & Различия в размерах правого и левого уха $\geq 15 \%$. \\
\hline $\begin{array}{l}\text { Низкое распо- } \\
\text { ложение ушных } \\
\text { раковин }\end{array}$ & $\begin{array}{l}\text { Определяется при сопоставлении верхней точки при- } \\
\text { крепления ушной раковины с уровнем латерального } \\
\text { угла глаза. }\end{array}$ \\
\hline $\begin{array}{l}\text { Короткий ми- } \\
\text { зинец }\end{array}$ & $\begin{array}{l}\text { Верхний его край совпадает или ниже уровня середины } \\
\text { 2-й фаланги 4-го пальца. }\end{array}$ \\
\hline $\begin{array}{l}\text { Сандалевидная } \\
\text { щель }\end{array}$ & $\begin{array}{l}\text { Расстояние между 1-м и 2-м пальцами нижних конеч- } \\
\text { ностей } \geq \text { ширины 2-го пальца. }\end{array}$ \\
\hline Синдактилия & Сращение пальцев > 1/3 длины одного пальца. \\
\hline $\begin{array}{l}\text { Гипертелоризм } \\
\text { сосков }\end{array}$ & $\begin{array}{l}\text { Вычисляется на основании соскового индекса }(\mathrm{Cи})- \\
\text { отношения расстояния между центрами сосков } \\
\text { и окружностью груди на уровне сосков (в \%). } \\
\qquad \text { Си }=a / b \times 100 \%, \\
\text { где } a-\text { расстояние между центрами сосков, } \\
b-\text { окружность груди на уровне сосков. } \\
\text { Гипертелоризм - при Си } \geq 28 \% .\end{array}$ \\
\hline
\end{tabular}




\section{3. Кдинико-генеалогический анализ}

Родословная - это укороченная система записи необходимой генетику информации о семье.

Генеалогический метод - метод составления родословных, т. е. прослеживание болезни (или признака) в семье с указанием родственных связей между членами семьи. В медицинской генетике этот метод можно назвать клинико-генеалогическим, поскольку речь идёт о наблюдении патологических признаков с помощью клинического обследования. Клинико-генеалогический метод включает в себя три этапа: сбор сведений о родственниках больного, составление родословной и анализ родословной.

\section{1. Сбор сведений о родственниках больного.}

При сборе семейного анамнеза помимо опроса родственников желательно использовать различные источники генеалогической информации, включая медицинскую (выписки из историй болезни, протоколы патологоанатомических исследований и др.). Важно провести осмотр и дополнительное обследование родственников больного в тех случаях, когда это необходимо и возможно.

Следует заметить, что пациенты иногда четко не представляют разницы между понятиями сибсы (дети одной родительской пары, т.е. родные братья и сестры) и полусибсы (полукровные братья и сестры), а также и то, что отчим, мачеха, пасынок, падчерица не являются кровными родственниками.

\section{2. Составление родословной.}

Для наглядности родословную изображают графически, пользуясь стандартными символами (рис. 8 и 9).

Лицо, с которого начинается составление родословной при генеалогическом анализе, называется пробандом (синонимы, встречающиеся в иностранной литературе - proband, propositus, index case) и помечается стрелкой. Информация об остальных членах семьи (пол, болезни, родственные связи и др.) тщательно выясняется и записывается в виде символов, а также в тексте легенды. 


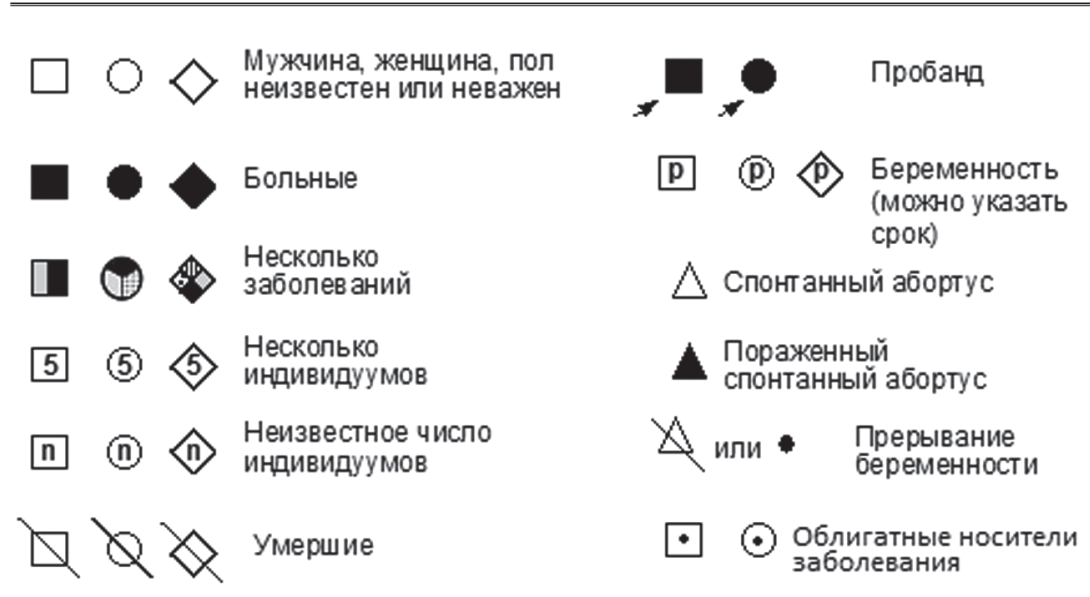

Рис. 8. Символы, используемые

для изображения индивидуумов в родословных
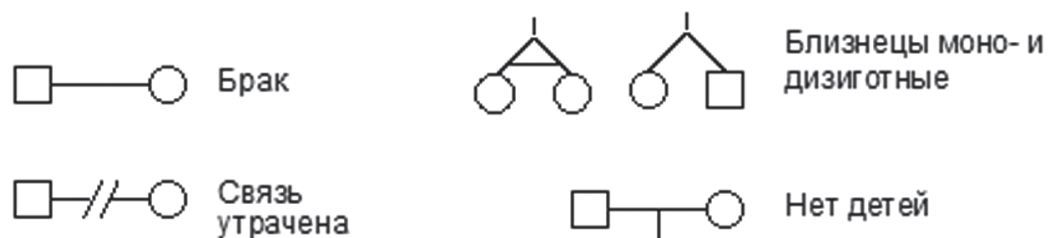

Связь

утрачена
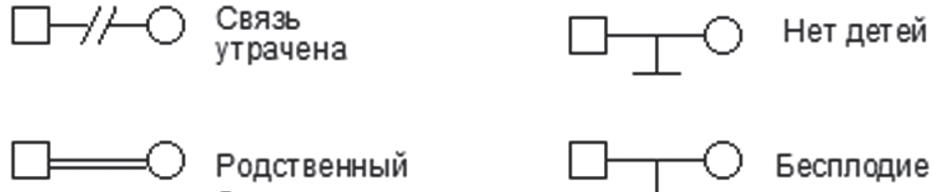

Родственный брак

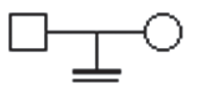

Бесплодие

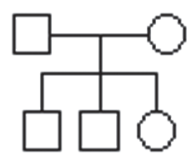

Сибсы

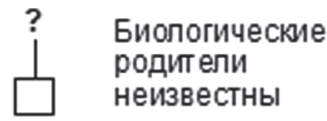

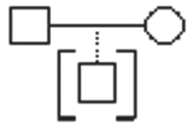

Усыновлен

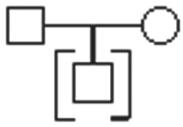

Биологические родители отказались от ребенка

Рис. 9. Символы, используемые для изображения связей между индивидуумами в родословных 
Поколения родословной нумеруют римскими цифрами сверху вниз. Обычно цифры ставят слева от родословной. Арабскими цифрами нумеруют потомство одного поколения последовательно слева направо. Братья и сестры располагаются в родословной в порядке рождения. Таким образом, каждый член родословной имеет свой порядковый номер, например, II-2, III-6, IV-9 (рис. 10). Обычно родословная собирается по одному или по нескольким признакам, поскольку исследователя, как правило, интересует конкретное заболевание или признаки.

\section{3. Анализ родословной.}

Первая задача при анализе родословной - установление наследственного характера признака или болезни. Если в родословной встречается один и тот же признак (или болезнь) несколько раз, то можно сделать предположение о его наследственной природе. После того как будет обнаружен наследственный характер признака (болезни), необходимо установить тип наследования. Типы наследования рассмотрены в разделе «Формальная генетика» (глава 5). Кроме того, анализ родословной позволяет установить предполагаемое носительство мутантного гена членами родословной, а также генетический риск рождения больного ребёнка у разных членов семьи.

\section{ГЯава 5. ФОРМАЯЬНАЯ ГЕНЕТИКА}

Генетика, как и любая другая наука, разделяется на фундаментальную и прикладную науку. К фундаментальной генетике относятся следующие разделы: классическая (формальная) генетика, цитогенетика, молекулярная генетика, эволюционная генетика, геномика и эпигеномика, генетика поведения, генетика популяций, экологическая генетика, математическая генетика. Формальная (классическая) генетика изучает, в числе многих исследований, и общие закономерности наследования признаков, а применительно к медицинской генетике - закономерности наследования различных заболеваний. 


\section{1. Моногенное насдедование}

Свыше 24000 признаков и заболеваний человека демонстрируют моногенное наследование. Данный тип наследования характерен для моногенных заболеваний (заболевания, связанные с нарушением последовательности ДНК одного гена). Выделяют следующие типы наследования моногенных заболеваний: аутосомно-доминантный и аутосомно-рецессивный, если аллели находятся на аутосомах; X-сцепленный доминантный и рецессивный, если ген локализован на хромосоме $X$; сцепленный с хромосомой Y, когда ген расположен на хромосоме Y; митохондриальный в случае мутаций в митохондриальной ДНК.

\subsection{1. Аутосомно-доминантное наследование}

Аутосомно-доминантные признаки (заболевания) проявляются в гетерозиготном сотоянии, т.е. тогда, когда у индивидуума есть нормальный и мутантный аллели. Иногда доминантные признаки можно проследить во многих поколениях родословной по вертикали (рис. 10). Так, в Южной Африке частым заболеванием является порфирия - нарушение синтеза гема, приводящее к накоплению и повышенной экскреции порфиринов и их предшественников, которые окрашивают мочу в красный цвет, вызывая повышенную фоточувствительность кожи и неврологическую симптоматику. Передачу этого заболевания удалось проследить вплоть до 17 века и до единственной супружеской пары, которая приехала на континент.

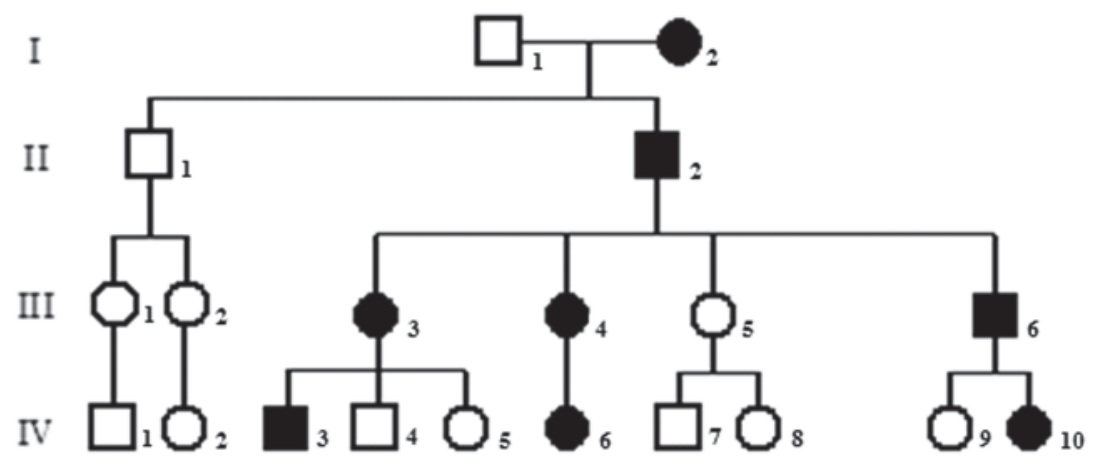

Рис. 10. Родословная при аутосомно-доминантном типе наследования 
Генетический риск при аутосомно-доминантном наследовании. Поскольку поражённый индивидуум имеет два типа гамет с нормальным и мутантным аллелем, то риск передачи болезни его ребёнку составляет $50 \%$.

Вариабельная экспрессивность. Клиническая картина аутосомно-доминантных болезней обычно чрезвычайно варьирует даже внутри одной и той же семьи. Такие различия между индивидуумами называют вариабельной экспрессивностью. Этим феноменом объясняются легкие и тяжелые формы заболеваний.

Неполная пенетрантность. Пенетрантность - частота проявления доминантного мутантного аллеля среди его носителей. Пенетрантность составляет $100 \%$, если заболевают все носители мутации. У некоторых индивидуумов, гетерозиготных по мутациям, вызывающим аутосомно-доминантные болезни, может не быть всех клинических признаков. Это явление называют «неполной пенетрантностью», которая может быть результатом модифицирующих эффектов других генов либо влияния средовых факторов.

Неполную пенетрантность и вариабельную экспрессивность мутантного аллеля следует принимать во внимание при медикогенетическом консультировании.

Мутации de novo. Обычно при аутосомно-доминантных болезнях больной имеет поражённого родителя, но нередко наблюдаются исключения. Например, при ахондроплазии - одной из форм карликовости - родители обычно нормального роста, так как каждый случай заболевания является результатом новой мутации (мутация de novo). Однако потомство больного будет поражено с риском $50 \%$. Появление новых доминантных мутаций связано с увеличеннием возраста отца вследствие большого числа митотических делений, которым подвергаются половые клетки мужчин в течение репродуктивного периода жизни.

Кодоминантность. Понятие кодоминантности используется для аллельных признаков, оба из которых выявляются в гетерозиготном состоянии. Примером может служить система групп крови у человека - AB0: при группе крови IV (AB) оба антигена А и В присутствуют в эритроцитах. 


\subsection{2. Аутосомно-рецессивное наследование}

Рецессивные признаки проявляются только в том случае, когда мутантный аллель присутствует в гомозиготном состоянии. Индивидуумы, гетерозиготные по этим признакам, не имеют фенотипических проявлений болезни, а являются ее носителями. В родословной заболевание прослеживается по горизонтали в одном поколении у сибсов (рис. 11).

\section{I \\ II}

III

IV

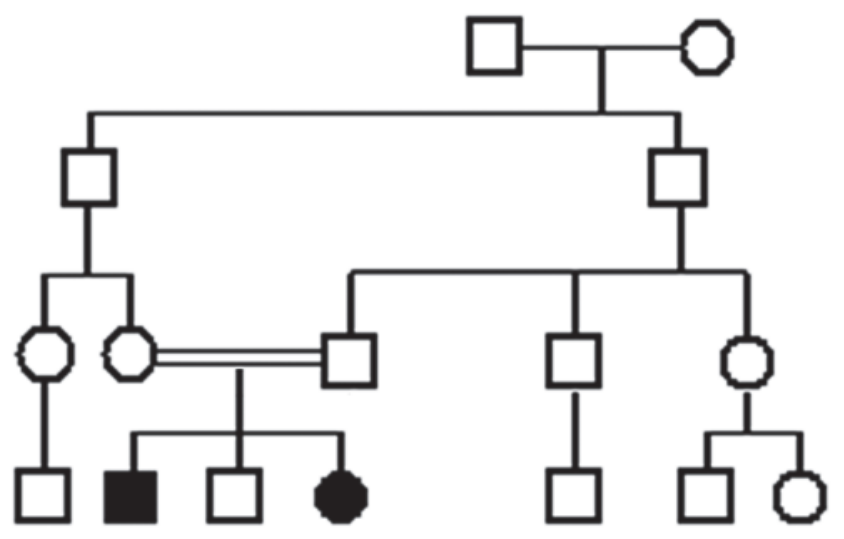

Рис. 11. Родословная при аутосомно-рецессивном типе наследования

Родственные браки. При аутосомно-рецессивных болезнях нередко можно выявить родственные связи между родителями. Например, при метаболическом заболевании алкаптонурии более четверти родителей - родственники. Однако, при частых аутосомно-рецессивных болезнях (таких, как муковисцидоз) частота родственных браков между родителями незначительна.

Генетический риск. Возможные комбинации гамет (25\% здоровых гомозигот по нормальному аллелю, 50 \% здоровых гетерозигот и $25 \%$ пораженных гомозигот по мутантному аллелю) приводят к вероятности рождения больного ребёнка, равной $25 \%$.

Компаундные гетерозиготы. При моногенных аутосомно-рецессивных болезнях идентифицировано большое число различных мутаций в одном гене. Сочетание двух различных мутаций 
в одном локусе, но в разных аллелях у индивидуума (компаундной гетерозиготы) носит название аллельной гетерогенности.

\subsection{3. Наследование, сцепденное с подом}

Х-сцепленное наследование принято делить на Х-сцепленное рецессивное и Х-сцепленное доминантное.

\section{$\mathrm{X}$-сцепленное рецессивное наследование}

Поскольку мужчины имеют только одну хромосому X, они являются гемизиготными по Х-сцепленным генам. Х-сцепленные рецессивные болезни проявляются у мальчиков, которые имеют только один мутантный аллель, а передаются здоровыми гетерозиготными женщинами-носительницами их сыновьям. Пораженные мужчины, в свою очередь, передают мутантный ген своим дочерям - облигатным носительницам, но не сыновьям. Этот тип передачи в родословной иногда называют «диагональным» (рис. 12).
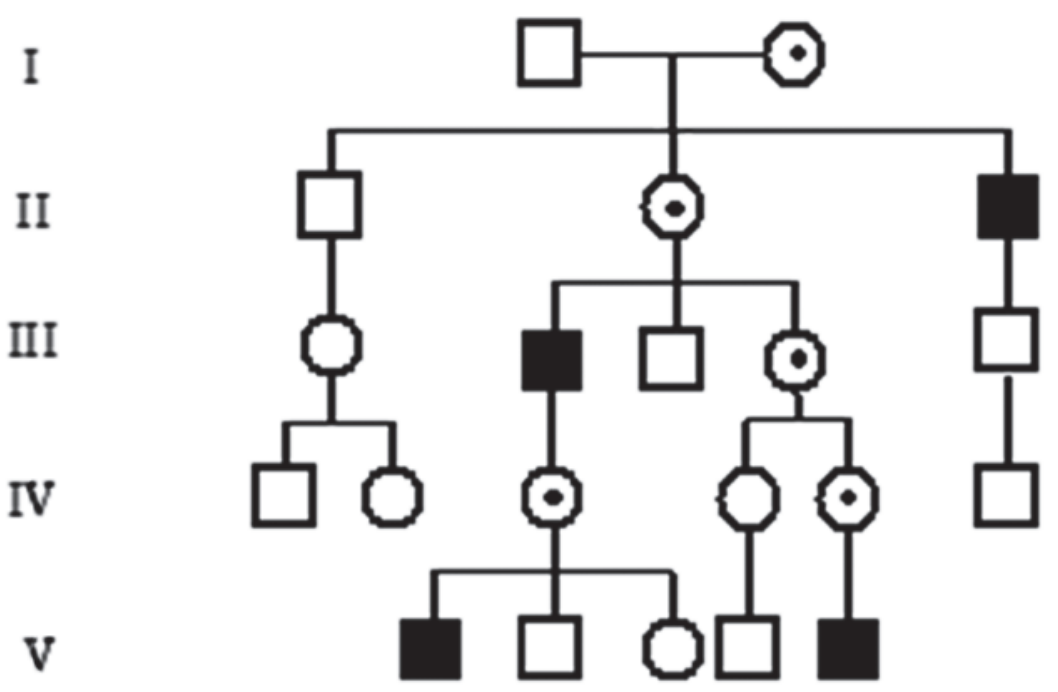

Рис. 12. Родословная при Х-сцепленном рецессивном типе наследования 
Генетический риск. Если облигатная носительница Х-сцепленной рецессивной мутации вступает в брак со здоровым мужчиной, то каждый их сын будет иметь $50 \%$-й риск заболевания, а каждая дочь - $50 \%$-й риск быть носительницей. Поскольку мужчина передаёт хромосому Х только своим дочерям, а хромосому Y - сыновьям, то все дочери поражённых мужчин от браков со здоровыми женщинами являются облигатными носительницами, а все их сыновья здоровы. Таким образом, мужчина не может передать Х-сцепленное заболевание своему сыну за очень редким исключением при унипарентальной гетеродисомии.

В качестве примера Х-сцепленного рецессивного заболевания можно привести мышечную дистрофию Дюшена. Это самая частая мышечная дистрофия, первыми признаками которой является переваливающаяся походка, трудности при подъёме по лестнице без болевых ощущений и тенденция к падениям ребёнка при ходьбе. Мышечная слабость прогрессирует, и поражённые мальчики умирают в конце второго - начале третьего десятилетия жизни. Таким образом, поражённые мужчины не имеют детей и не передают соответствующие мутации потомкам (рис. 13).

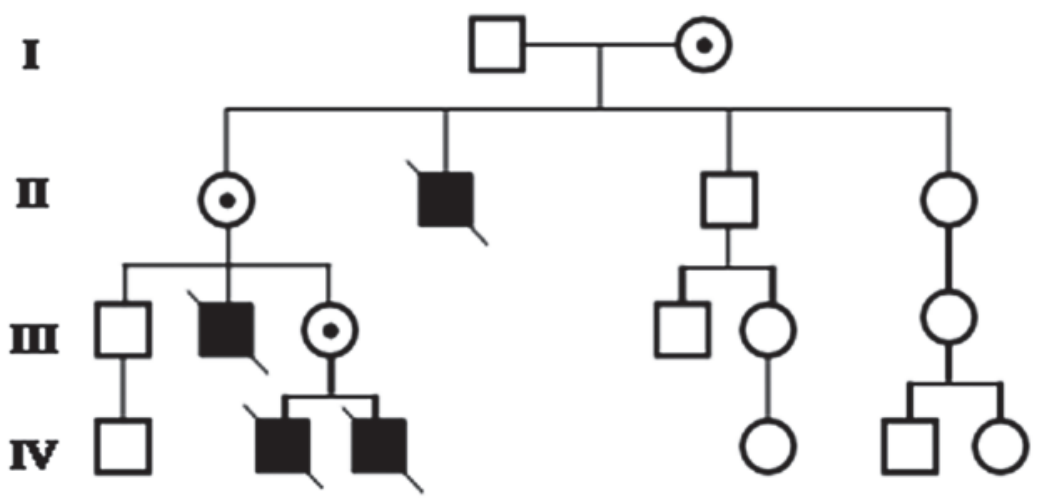

Рис. 13. Родословная семьи с мышечной дистрофией Дюшена 
Вариабельная экспрессивность у женщин-гетерозигот. При многих Х-сцепленных болезнях женщины-гетерозиготы имеют мозаичный фенотип. Например, при X-сцепленном альбинизме радужная оболочка и глазное дно больных мужчин не имеют пигмента, а у гетерозиготных женщин выявляется мозаичная (пятнистая) пигментация. Это объясняется феноменом X-инактивации.

\section{$\mathrm{X}$-сцепленное доминантное наследование}

$\mathrm{X}$-сцепленные доминантные болезни являются редкими и выявляются у женщин-гетерозигот, а также у мужчин-гемизигот, имеющих мутантный аллель на единственной хромосоме X. X-сцепленное доминантное наследование напоминает аутосомно-доминантное. Но есть значимое отличие: поражённые мужчины передают заболевание только своим дочерям, а передача от отца к сыну невозможна (рис. 14). Примером этого типа наследования является витамин Д-резистентный рахит, при котором женщины обычно имеют более легкие формы заболевания, чем мужчины.

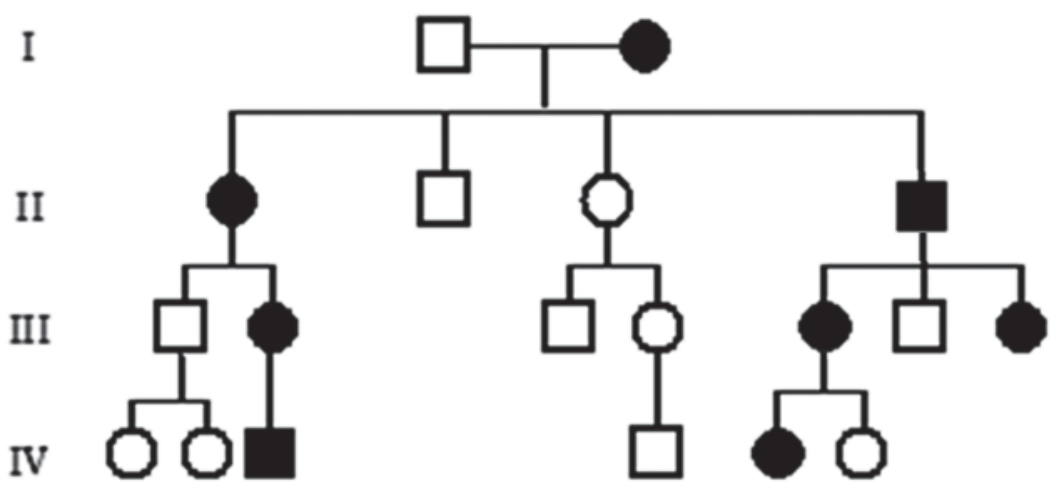

Рис. 14. Родословная при Х-сцепленном доминантном типе наследования

При многих Х-сцепленных доминантных болезнях у женщин может наблюдаться мозаицизм проявления болезни. Например, 
при синдроме Блоха-Сульцбергера (синдром недержания пигмента, тип II) наблюдается мозаичная пигментация кожи. Кроме того, это заболевание, также как синдром Ретта, является примером болезни, летальной для плодов мужского пола.

\section{Наследование, сцепленное с хромосомой Y}

Наследование, сцепленное с хромосомой Y, предполагает то, что болеют только мальчики. Заболевание передается только от отца к сыну. В случае мутаций в генах хромосомы Y, вовлеченных в сперматогенез, возникает бесплодие вследствие азооспермии у мужчин. Технологии искусственного оплодотворения позволяют им иметь детей, но если при этом рождается сын, он также страдает азооспермией.

Влияние пола. Некоторые аутосомные признаки значительно чаще выявляются у одного из полов. Этот феномен получил название влияние пола. Лысина у мужчин является примером аутосомно-доминантного признака, ограниченного полом, что, по-видимому, является результатом влияния мужских половых гормонов. Другой пример - подагра, которая является очень редким состоянием у женщин до менопаузы, но после нее частота этого заболевания возрастает. При гемохроматозе (аутосомно-рецессивном заболевании) у женщин-гомозигот намного реже возникает перегрузка железом и связанные с ней симптомы, чем у мужчин-гомозигот. Объяснением является физиологическая потеря железа женщинами во время менструаций.

\section{Ограничение полом наследование}

Ограничение полом наследование связано с проявлением определенных признаков у индивидуумов только одного пола. Например: вирилизация девочек с аутосомно-рецессивным эндокринным заболеванием - врождённой гиперплазией коры надпочечников.

В таблице 5 кратко представлены основные признаки менделевских типов наследования. 


\section{Таблица 5}

\section{Признаки различных типов наследования и особенности заболевания у лиц разного пола}

\begin{tabular}{|c|c|c|}
\hline $\begin{array}{c}\text { Тип } \\
\text { наследования }\end{array}$ & $\begin{array}{c}\text { Особенности заболевания } \\
\text { у лиц разного пола }\end{array}$ & $\begin{array}{c}\text { Особенности передачи } \\
\text { в родословной }\end{array}$ \\
\hline $\begin{array}{l}\text { Аутосомно- } \\
\text { доминантный }\end{array}$ & $\begin{array}{l}\text { Мужчины и женщины } \\
\text { болеют в равной про- } \\
\text { порции }\end{array}$ & $\begin{array}{l}\text { «Вертикальный» тип пере- } \\
\text { дачи - больные во многих } \\
\text { поколениях родословной. } \\
\text { Передача от лица любого пола } \\
\text { лицу любого пола. }\end{array}$ \\
\hline $\begin{array}{l}\text { Аутосомно-ре- } \\
\text { цессивный }\end{array}$ & $\begin{array}{l}\text { Мужчины и женщины } \\
\text { болеют в равной про- } \\
\text { порции }\end{array}$ & $\begin{array}{l}\text { «оризонтальный» тип пере- } \\
\text { дачи - больные в одном по- } \\
\text { колении. Родители больного } \\
\text { (больных) нередко могут быть } \\
\text { родственниками. }\end{array}$ \\
\hline $\begin{array}{l}\text { Х-сцепленный } \\
\text { рецессивный }\end{array}$ & $\begin{array}{l}\text { Как правило, больны } \\
\text { мужчины }\end{array}$ & $\begin{array}{l}\text { «Диагональный» тип пере- } \\
\text { дачи: мужчины не могут } \\
\text { передавать заболевание своим } \\
\text { сыновьям. Возможна передача } \\
\text { только внуку от деда через его } \\
\text { дочь, которая является непо- } \\
\text { ражённой облигатной носи- } \\
\text { тельницей. }\end{array}$ \\
\hline $\begin{array}{l}\text { Х-сцепленный } \\
\text { доминантный }\end{array}$ & $\begin{array}{l}\text { Болеют мужчины и жен- } \\
\text { щины с преобладанием } \\
\text { женщин. Женщины } \\
\text { поражены в меньшей } \\
\text { степени, чем мужчины. } \\
\text { В случае летальных для } \\
\text { мальчиков болезней по- } \\
\text { ражены только девочки, } \\
\text { наблюдаются спонтан- } \\
\text { ные аборты в семье. }\end{array}$ & $\begin{array}{l}\text { Поражённые мужчины могут } \\
\text { передавать заболевание своим } \\
\text { дочерям, но не сыновьям. Пе- } \\
\text { редача от мужчины к мужчине } \\
\text { исключает Х-сцепленный тип } \\
\text { наследования. }\end{array}$ \\
\hline $\begin{array}{l}\text { Сцепленный } \\
\text { с хромосомой } \\
\text { Y }\end{array}$ & $\begin{array}{l}\text { Болеют только мужчи- } \\
\text { ны. }\end{array}$ & $\begin{array}{l}\text { Поражённые мужчины могут } \\
\text { передавать заболевание только } \\
\text { своим сыновьям. }\end{array}$ \\
\hline
\end{tabular}




\section{2. Мультифакторное (многофакторное) наследование}

Согласно современным данным, на долю мультифакторных болезней приходится около $90 \%$ всей патологии человека. Известно, что такие заболевания, как гипертоническая болезнь, диабет, астма, аутизм, эпилепсия, шизофрения, биполярный психоз и т. Д., контролируются многими генами (полигенная основа наследования), а множество средовых факторов также влияют на возникновение этих заболеваний. Преобладает мнение о том, что при этих состояниях неаллельные гены, расположенные в различных локусах, взаимодействуют, создавая предрасположенность к неблагоприятным факторам окружающей среды. Тип наследования этих заболеваний было принято называть мультифакториальным, но, вероятно, правильнее его называть мультифакторным (или многофакторным), а риск повторного рождения больного ребёнка определять по специально разработанным таблицам, составленным на основании эпидемиологических исследований (см рекомендуемую литературу). Знание генетических механизмов и роли средовых факторов в формировании мультифакторной (многофакторной) патологии дает возможность врачу осуществлять полноценную лечебную коррекцию этих патологических состояний и проводить эффективные профилактические мероприятия.

\section{3. Митохондриадьное наследование}

Митохондриальное (цитоплазматическое) наследование характерно для особого класса наследственной патологии - митохондриальных болезней. Каждая клетка содержит тысячи копий митохондриальной ДНК. Ряд редких болезней с необычной комбинацией неврологических и миопатических признаков, кардиомиопатии, диабет, как оказалось, возникают вследствие мутаций митохондриальных генов. Неудивительно, что головной мозг, мышцы и сердце поражаются в большей степени, поскольку эти органы наиболее энергозависимы. Митохондриальные болезни поражают оба пола, но передаются только через женщин (рис. 15). У большинства людей митохондриальная ДНК идентична во всех митохондриях 
(гомоплазмия). В случае мутаций ДНК в части митохондрий, у индивидуума будет две популяции митохондрий - нормальные и мутантные, т. е. гетероплазмия. Доля митохондрий с мутантной ДНК варьирует между клетками и тканями. Это является объяснением различной тяжести течения заболевания у людей с митохондриальными болезнями. Ряд митохондриальных белков кодируется ядерными генами, а мутации в них нарушают функцию митохондрий. Напрмер, мутации генов белков комплекса цитохрома С наследуются аутосомно-рецессивно, а мутации Х-сцепленного гена $G 4.5$ (TAZ) вызывают синдром Барта (кардиоскелетную миопатию с нейтропенией и аномальными митохондриями) у мальчиков.

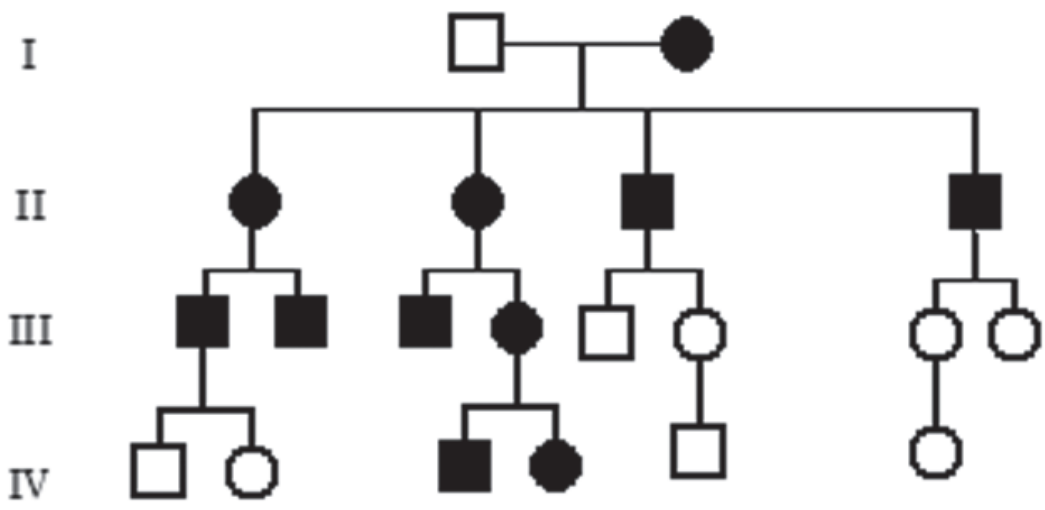

Рис. 15. Родословная при митохондриальном типе наследования

\section{Множественные аллели и комплексные признаки}

Выше рассмотрены признаки, с которыми связаны только два аллеля - нормальный и мутантный. Некоторые гены имеют более двух аллельных форм, т. е. множественные аллели. Некоторые из них могут быть доминантными, другие - рецессивными по отношению к нормальному аллелю. Пример множественных аллелей - наследование групп крови человека. 
Развитие генетики сделало возможным исследование комплексных признаков, которые формируются при взаимодействии нескольких генов. На этой основе возникла концепция олигогенного (дигенного и триаллельного) наследования.

При дигенном наследовании наблюдается аддитивный эффект гетерозиготных мутаций в двух различных локусах. Например, одна из форм пигментного ретинита, приводящая к потере зрения, вызвана гетерозиготностью по мутациям двух генов (ROM1 и PRPH). Оба эти гена кодируют белки, присутствующие в фоторецепторах сетчатки глаза. Индивидуумы, гетерозиготные по мутации только одного из этих двух генов, не имеют клинических проявлений.

Триаллельное наследование можно рассмотреть на примере синдрома Барде-Бидля - редкого заболевания, характеризующегося ожирением, полидактилией, аномалиями почек, пигментным ретинитом и когнитивными нарушениями. Семь различных генных локусов, мутации в которых ведут к синдрому Барде-Бидля, были идентифицированы. До недавнего времени считалось, что заболевание наследуется аутосомнорецессивно. Однако, сейчас известно, что есть одна форма синдрома, когда индивидуум, гомозиготный по мутациям одного локуса, является также гетерозиготным по мутации другого локуса. Таким образом, для того, чтобы заболевание проявлялось, необходимо три мутантных аллеля.

Антиципация. При некоторых аутосомно-доминантных болезнях манифестация симптомов более ранняя и течение болезни более тяжелое у потомков по сравнению с их родителями, также страдающими этим заболеванием. Феномен увеличения тяжести болезни из поколения в поколение называют антиципацией. Одним из объяснений антиципации является экспансия нестабильных триплетных повторов. В качестве примеров можно привести такие болезни экспансии триплетных повторов, как миотоническая дистрофия, хорея Гентингтона, болезнь Кеннеди. 


\section{Гдава 6. ВРОЖДЁННЫЕ АНОМАЛИИ И СИНДРОМЫ}

Известно, что морфогенез иеловека включает сложные взаимодействия генетических и средовых факторов. Нарушения морфогенеза ведут к возникновению врождённых аномалий.

Частота врождённых аномалий. Показано, что морфологические аномалии находят в 80-85\% случаев спонтанных абортов. От 25 до $30 \%$ случаев перинатальной смертности являются следствием пороков развития. Среди новорожденных 2-3\% имеют, по крайней мере, один порок развития при рождении, а если учесть позже выявляемые аномалии, то их число приближается к $5 \%$. Принимая во внимание новорожденных и спонтанных абортусов, можно заключить, что около $15 \%$ распознанных зачатий являются аномальными. МАР наблюдают у $10 \%$ новорожденных. Если две и более микроаномалии присутствуют у новорожденного, то у него 10-20\% риск иметь еще и порок развития. Врождённые аномалии вносят значительный вклад в структуру детской смертности. Около $25 \%$ смертей на первом году жизни - результат пороков развития. Эта пропорция уменьшается до $20 \%$ в возрасте 1-10 лет и до 7,5\% для детей 10-15 лет.

Генетические факторы лежат в основе, по крайней мере, половины всех врождённых пороков. Ниже приведен перечень наиболее частых пороков развития:

Микроцефалия

Анэнцефалия

Голопрозенцефалия

Энцефалоцеле

Менингомиелоцеле

Микрофтальмия и другие пороки развития глаз

Атрезия слуховых проходов

Расщелина губы и неба 
Костные дефекты (пороки позвоночника, сколиоз, радиоульнарный синостоз, косолапость, вывих тазобедренных суставов и др.)

Микромелия (гипоплазия конечностей)

Аплазия дистальных фаланг

Аплазия грудной мышцы

Пороки сердца

Атрезия пищевода

Атрезия ануса

Грыжи пищевода, диафрагмы

Кистофиброз печени (у новорожденных)

Пороки мочевыделитеной системы (гипоплазия, дистопия, поликистоз почек)

Пороки гениталий (гипоспадия, гипоплазия полового члена, микро- и анорхизм; атрофия семявыносящих канальцев; удвоение влагалища; удвоение, аплазия матки, двурогая матка).

\section{1. Классификация врождённых аномадий}

Различают изолированные аномалии (примеры, расщелина твёрдого нёба, врождённый дефект межжелудочковой или межпредсердной перегородки сердца), системные аномалии (в пределах одной системы органов, например, скелетные дисплазии) и множественные аномалии (затрагивают две и более системы органов).

Изолированные врождённые аномалии. Среди изолированных врождённых аномалий различают мальформации, дизрупции, деформации и дисплазии (рис. 16). Последние правильнее отнести к системным аномалиям. Схема нарушений морфогенеза представлена на рисунке 16.

Мальформация - это первичный структурный дефект органа или его части, который является результатом генетических нарушений. Мальформация подразумевает то, что раннее внутриутробное развитие определенной ткани или органа было нарушено. Частые примеры мальформаций - это врождённые пороки сердца, расщелина губы и нёба, дефекты нервной трубки. Большинство мальформаций, затрагивающих только единичный 
орган, являются мультифакторными признаками. Множественные мальформации наиболее часто возникают вследствие хромосомных аномалий.

\section{Зачатие}

\section{Рождение}

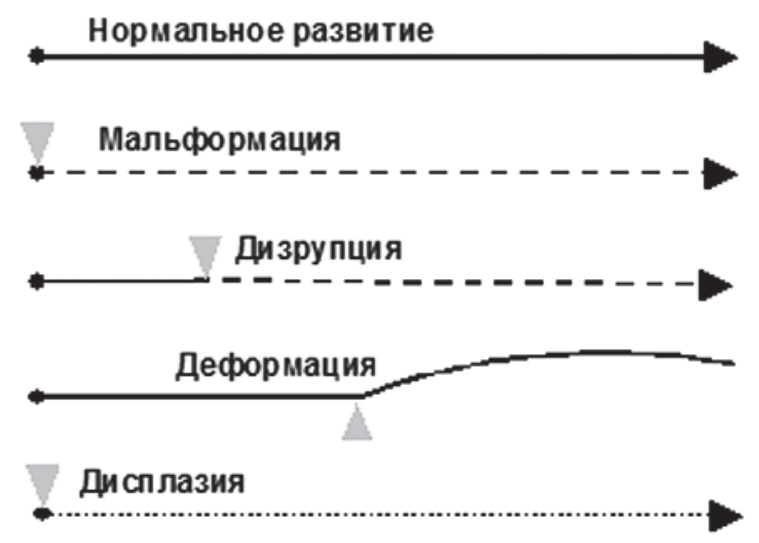

\section{Сплошная прямая линия - нормальное развитие, пунктирные и кривая линии - аномальное развитие, серый треугольник - начало воздействия этиологического фрактора.}

Рис. 16. Схема нарушений морфогенеза

Дизруция - возникновение аномальной структуры органа или ткани в результате воздействия внешних факторов, нарушающих процесс нормального развития. Её вызывают такие внешние факторы, как ишемия, инфекция, травма и др. Примером дизрупции является нарушение развития конечностей плода вследствие приёма матери препарата талидомид. По определению дизрупция негенетическое событие.

Деформация - результат механических воздействий, которые искажают морфологию плода. Например, дислокация бедра может быть вызвана недостатком амниотической жидкости (олигогидрамнион) или многоплодной беременностью, либо структурной аномалией матки. Деформации обычно возникают во второй половине беременности и имеют хороший прогноз при адекватном лечении. 
Дисплазия - аномальная организация клеток в ткани. Например, при эктодермальной дисплазии вовлечены все ткани эктодермального происхождения - поражаются кожа, ногти, волосы и др. Большинство дисплазий вызываются моногенными дефектами и связаны с высоким риском рождения детей с данной аномалией в семье.

Множественные врождённые аномалии: секвенции, синдромы и ассоциации.

Секвенция - комплекс признаков, являющихся следствием каскада событий, инициированных одним фактором. Например, при секвенции Поттера хроническое подтекание амниотической жидкости либо нарушение образования мочи ведет к олигогидрамниону, что, в свою очередь, ведет к компрессии плода, формированию «помятого» лица, дислокации бедер, пяток и гипоплазии легких, что может вызвать неонатальную гибель ребёнка от дыхательной недостаточности (рис. 17).

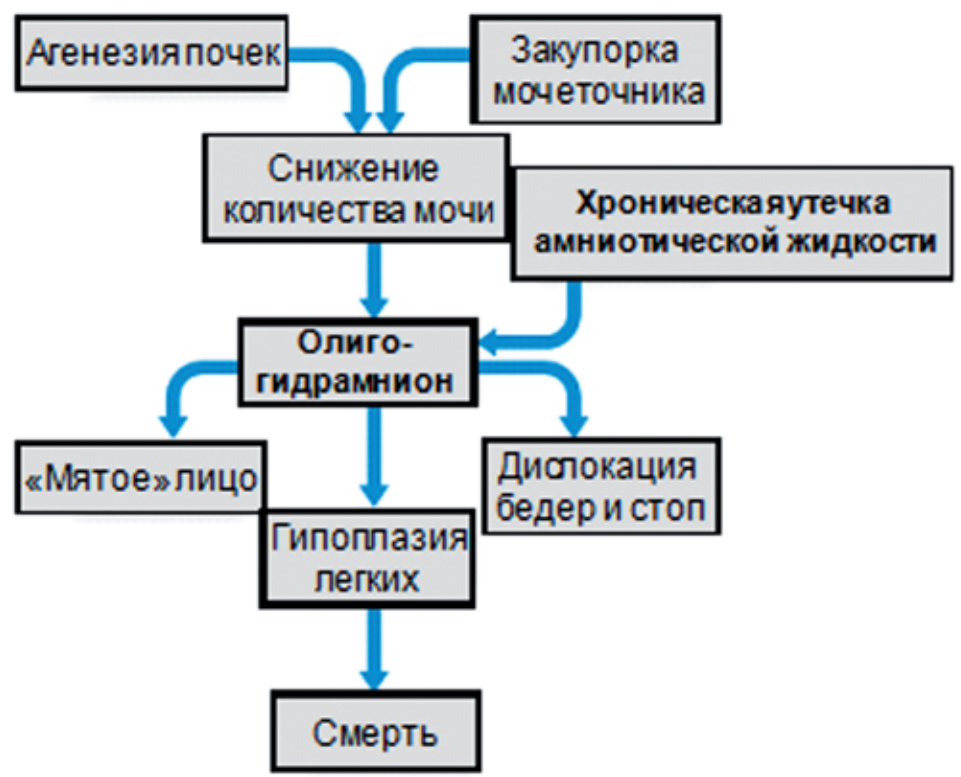

Рис. 17. Секвенция: каскад событий, ведущий к уменьшению количества амниотической жидкости (олигогидрамнион) 
Синдром - распознаваемый комплекс аномалий, этиология которых известна. Примерами являются хромосомные и моногенные синдромы. Диагностика синдромов значительно облегчается существованием электронных баз данных, таких как POSSUM (Pictures of Standard Syndromes and Undiagnosed Malformations), Лондонская база данных и др.

Ассоциаци - понятие, которое возникло в связи с тем, что некоторые аномалии имеют тенденцию встречаться в сочетании друг с другом, а не случайно, и это необъяснимо с позиций секвенции или синдрома. Основным отличием ассоциации от синдрома является непостоянство набора аномалий у разных больных. Примером является VATER-ассоциация - комплекс из вертебрального, анального, трахео-эзофагального и ренального пороков. Ассоциации имеют низкий рекуррентный риск, и причина их не ясна.

Что касается структуры причин врождённых аномалий развития, то генетически обусловленные формы составляют 20-30\%, мультифакторные - 30-40\%, экзогенные $-2-5 \%$, неизвестной этиологии - 25-50\%.

\section{2. Генетические причины врождённых аномадий}

Многие причины врождённых аномалий известны, причины около $50 \%$ случаев остаются невыясненными. Хромосомные аномалии составляют около трети всех наблюдаемых врождённых аномалий. Как правило, хромосомный дисбаланс ведет к множественным тяжёлым врождённым порокам развития, иногда несовместимым с жизнью. Моногенные дефекты составляют около 7,5\% всех врождённых аномалий. Некоторые из них ведут к изолированным врождённым аномалиям, другие - к синдромам множественных врождённых пороков, затрагивающих многие органы и их системы. Например, эктродактилия может наследоваться как аутосомно-доминантный, аутосомно-рецессивный и, редко, как $\mathrm{X}$-сцепленный признак. Она также может входить в симптомокомлекс определенного синдрома (например, аутосомно-доминантный синдром ЕЕС - экодермальная дисплазия, эктродактилия и расщелина губы и нёба). 
Многофакторное наследование характерно для ряда несиндромальных врождённых аномалий сердца, центральной нервной системы. Для многих из них известны риски, выявленные эмпирическим путем на основе эпидемиологических исследований. Для ряда специфических врождённых мальформаций характерна генетическая гетерогенность. Некоторые наиболее частые врождённые аномалии представлены ниже.

Голопрозенцефалия. Эта тяжелая и часто летальная мальформация представляет собой нарушение развития такой области эмбрионального мозга, как передний мозг или прозенцефалон. Голопрозенцефалия характеризуется полным или частичным нарушением деления переднего мозга по средней линии и формированием гемисфер, что ведет к нарушениям не только структуры мозга, но и к развитию срединных лицевых структур (например, возникновению циклопии), а также к глубоким нарушениям психомоторного развития. Тяжесть аномалий лица обычно соответствует тяжести поражения структур мозга. Частота голопрозенцефалии составляет около 6-12 на 10000 среди новорожденных. Половина этих случаев связана с трисомией хромосомы 13. При голопрозенцефалии наблюдается преобладание лиц женского пола.

Голопрозенцефалия может быть этиологически классифицированна на хромосомную, синдромальную и изолированную, связанную с мутациями в определённых генах. Причины, связанные с аномалиями хромосом, составляют 30-40\% случаев голопрозенцефалии, наиболее частой является трисомия хромосомы 13. Среди других причин могут быть делеции хромосом в участках 2p11, 7q36, 18p11.3 и 21q22.3, дупликации хромосом в участках 3p24 $\rightarrow$ pter и 13q, а также триплоидии. Синдромальные причины голопрозенцефалии многочисленны, например, синдром Смита-Лемли-Опица. Причинами изолированной голопрозенцефалии могут быть мутации ряда генов (SHH, ZIC2, SIX3).

Дефекты нервной трубки. Эти врождённые пороки являются результатом аномального закрытия развивающейся нервной трубки в эмбриональном периоде. Дефект верхнего конца 
развивающейся нервной трубки ведёт либо к анэнцефалии (врождённое отсутствие головного или спинного мозга), либо к энцефалоцеле (выпячивания мозга через имеющийся в черепе дефект). Дефекты нижней части нервной трубки ведут к таким спинальным порокам, как пояснично-крестцовое миелоцеле или менингомиелоцеле (выпячивания спинного мозга и его оболочек через незаращение дужек позвонков). Анэнцефалия несовместима с жизнью. Крупные пороки в пояснично-крестцовой области вызывают частичный или полный паралич нижних конечностей с нарушением функций мочевого пузыря и кишечника.

Дефекты нервной трубки также могут быть классифицированы как хромосомные, синдромальные и изолированные. Причины, связанные с аномалиями хромосом, включают трисомии хромосом 13 и 18, при которых дефекты нервной трубки встречаются в 5-10\% случаев. Среди моногенных причин следует отметить относительно редкое аутосомно-рецессивное заболевание - синдром Меккеля, при котором энцефалоцеле сочетается с поликистозом почек и полидактилией. Тем не менее, большинство дефектов нервной трубки представляют собой изолированные пороки и наследуются мультифакторно. Эмпирический риск варьирует согласно региональной частоте и достигает 4-5\%. Например, у жителей Англии частота данной патологии выше, чем у остальных национальностей кельтского происхождения.

Известно, что мутации в гене метилентетрагидрофолатредуктазы являются предрасполагающим фактором к дефектам нервной трубки. Мутация данного гена ведёт к снижению активности одноименного фермента, являющегося ключевым в обмене фолиевой кислоты, и наиболее опасна в условиях дефицита фолатов в питании. Нарушения обмена фолатов ведут к нарушениям образования пуринов и пиримидинов, необходимых для синтеза ДНК. Профилактика, проводимая при помощи введения в диету витаминов, в частности, фолиевой кислоты за несколько месяцев до зачатия, а также в первые месяцы беременности, уменьшает риск повторного рождения ребенка с пороком нервной трубки в семье на 70-75\%. Во многих 
странах (США, Великобритания, Венгрия, Мексика) принято обогащать муку и хлеб фолиевой кислотой, что приводит к заметному снижению частоты пороков нервной трубки.

Анэнцефалия. Это многофакторный практически летальный врождённый порок, характеризующийся отсутствием мозга (нередко отсутствует передний и средний отдел головного мозга) с частичным отсутствием костей свода черепа и скальпа. Вместо мозговой ткани разрастается соединительная ткань с кистозными полостями и единичными нервными клетками. Кости черепа отсутствуют, в ряде случаев представлены хрящевыми образованиями с островками лобных и теменных костей. Ствол мозга обычно недоразвит, иногда нарушается и задний мозг. Популяционная частота этого порока - 1:1000 новорожденных.

Энщефалоцеле (черепно-мозговая грыжа). Это грыжевое выпячивание головного мозга или его оболочек через дефект костей черепа в связи с их нарушением. Чаще это происходит в местах соединения костей черепа (между лобными костями, теменными и затылочными, теменными и височными). Популяционная частота этого врождённого порока - 2-4 на 10000 новорожденных. Изолированные формы черепно-мозговых грыж относятся к порокам многофакторной этиологии. Черепно-мозговые грыжи делят на менингоцеле, при которой грыжевой мешок представлен мозговыми оболочками, а содержимое - спинномозговой жидкостью; энцефаломенингоцеле, при которой в грыжевой мешок выпячивается тот или иной отдел головного мозга (кора, мозжечок и другие отделы). Грыжи могут быть связаны с гидроцефалиями, атаксиями, судорогами, задержкой развития, нарушениями зрения и др. Крупные грыжи приводят к смерти.

Расщелина губы с/без расщелины нёба. Этот порок развития имеет, в основном, многофакторное происхождение, но может быть и в результате действия тератогенов (применение противосудорожных препаратов во время беременности: фенитоин, фенобарбитал, вальпроевая кислота). Популяционная частота - 1 случай на 1000 новорожденных. Этот врождённый порок может быть составной частью множественных ВПР различной этиологии. Расщелина губы с или без расщелины нёба возникает 
в связи с нарушением развития эмбриональных лицевых отростков на 5-6 неделях беременности, что приводит к несращению. Дефект может проявляться как односторонним, так и двусторонним нарушением; клинически порок варьирует от расщелины губы до сквозной расщелины, которая может сопровождаться деформацией и асимметрией крыльев носа, искривлением носовой перегородки, аномалией зубов. При сквозной (полной) расщелине имеется сообщение между носовой и ротовой полостями, что приводит к нарушению глотания и дыхания. С возрастом возникают нарушения звукообразования и речи.

Анофтальмия/микрофтальмия. Этот врождённый порок связан с отсутствием/недоразвитием глазного яблока в результате задержки развития глаза на разных стадиях роста глазного пузыря. Популяционная частота этих пороков 1,6 на 10000 новорожденных. В этиологии особую роль играют наследственные факторы: аутосомно-доминантные, аутосомно-рецессивные и Х-сцепленные формы наследственных заболеваний. Изолированные анофтальмия/микрофтальмия чаще всего встречаются спорадически. Анофтальмия/микрофтальмия могут входить в состав множественных ВПР как наследственного генеза, так и тератогенной природы (приём антикоагулянта варфарина, воздействие ионизирующей радиации). К этим порокам могут приводить инфекционные болезни матери во время беременности (краснуха, токсоплазмоз, цитомегаловирусная инфекция).

Гипоспадия. Этот врождённый порок развития связан с открытием выходного отверстия уретры на вентральной поверхности полового члена от нижней поверхности головки до мошонки и промежности. Популяционная частота гипоспадии 3 случая на 1000 новорожденных мальчиков. В крайне редких случаях данная аномалия встречается у девочек. При женской гипоспадии отсутствуют задняя стенка уретры и передняя стенка влагалища на различном протяжении; при этом, недоразвиты малые половые губы, часто отсутствует клитор. Этот порок у девочек часто сочетается со свищом прямой кишки во влагалище. У мальчиков к развитию этого порока может приводить нарушение синтеза тестостерона у плода, а также влияние 
повышенной концентрации эстрогена на плод в период внутриутробного развития. Предполагается мультифакторная природа наследования этого порока развития.

Атрезия ануса. Это врождённый порок связан с отсутствием непрерывности сообщения между прямой кишкой и анусом или выраженным сужением анального канала с/без свища в соседние органы. Частота изолированной атрезии ануса составляет 1,5 случая на 10000 , и этот порок развития относится к мультифакторной патологии. В большинстве случаев (до 70 \%) эта аномалия сочетается с другими ВПР желудочно-кишечного тракта (атрезии пищевода и двенадцатиперстной кишки), мочеполовой системы (гипоспадия), брюшной стенки (омфалоцеле), а также входит в состав признаков различных наследственных синдромов. Клинически у новорожденных выявляют отсутствие естественного анального отверстия, затем признаки кишечной непроходимости.

Диафрагмальные грыжи. Этот врождённый порок развития характеризуется грыжевым выпячиванием органов брюшной полости в грудную полость через дефект диафрагмы. Частота порока составляет 1 случай на 2500 новорожденных. Часто диафрагмальная грыжа входит в состав известных хромосомных и генных синдромов. Изолированная форма имеет мультифакторное происхождение. Дефекты диафрагмы бывают различного размера: от небольших до полного отсутствия купола диафрагмы. В зависимости от величины отверстия в грудную полость перемещаются селезёнка, желудок, петля кишки, левая доля печени. Эти органы смещают органы средостения, при этом сердце не только смещается, но и переворачивается вокруг продольной оси, натягивая и деформируя полые вены. Указанные перемещённые органы сдавливают лёгкое.

Омфалоцеле. Это врождённый порок, характеризующийся протрузией кишечника и других органов брюшной полости в полость пупочного канатика. Это относительно частый порок у новорожденных, частота его составляет 1 на 4000-6000 новорожденных. Этиология порока гетерогенна. Изолированный порок чаще всего встречается спорадически. Многие исследователи 
указывают на возможность тератогенного возникновения порока (например, приём противосудорожных препаратов: вальпроевой кислоты во время первого триместра беременности). Омфалоцеле является также симптомом некоторых наследственных синдромов. Этот порок представляет собой грыжу пупочного канатика. Размеры пупочного кольца колеблются от небольших (2-4 см в диаметре) до массивного дефекта, занимающего всю брюшную полость. При гигантской грыже печень центрально расположена и полностью занимает грыжевой мешок. Для детей с гигантской грыжей характерны маленькая колоколообразная грудная полость, гипоплазия лёгких, дыхательные расстройства. В последнее время выживаемость детей с омфалоцеле заметно повышается за счёт повышения качества лечения детей с этим пороком.

Атрезия/стеноз пищевода. Этот врождённый порок связан с сужением пищевода или с отсутствием его непрерывности. Частота порока у новорожденных составляет 1 случай на 3000-5000. Изолированная атрезия пищевода встречается с частотой 1 случай на 4000-5000 новорожденных. Данный порок часто выявляется при различных хромосомных синдромах (синдромы Дауна, Эдвардса и др.); встречаютя также в сочетании с другими врождёнными пороками развития: желудочно-кишечного тракта (атрезия прямой кишки и ануса), мочеполовой системы (агенизия почек, гипоспадия), с пороками сердца, центральной нервной системы и лицевыми аномалиями. Часто атрезия пищевода выявляется со свищом между трахеей и пищеводом (его дистальной частью). Изолированная аномалия без свища встречается реже. Симптомы атрезии пищевода у ребёнка выявляются сразу после рождения и выражаются в нарушении гортани и регургитации пищи. При наличии свища наблюдаются нарушения дыхания, приступы удушья, кашель во время кормления или после него. У детей с данным врождённым пороком часто развиваются аспирационные пневмонии.

Транспозиция магистральных сосудов. Этот врождённый порок сердца, так называемого синего типа, при котором аорта отходит от правого желудочка сердца, а лёгочная артерия - от левого 
желудочка, обнаруживается в первые дни жизни ребёнка. Частота этого порока составляет 4 случая на 10000 новорожденных. Данный ВПР имеет мультифакторное происхождение; описаны случаи развития этого порока после приёма алкоголя и лекарств во время беременности (талидомид, фенитоин). Эти пороки встречаются после перенесённой фенилкетонурии и при сахарном диабете. Клинически характерными проявлениями порока являются сердечные шумы над дефектом, одышка, цианоз, иногда судороги, отставание в физическом развитии, деформация грудной клетки («сердечный горб»).

Гипоплазия левого сердца. Этот врождённый порок связан с недоразвитием левого сердца: предсердия, желудочка, митрального и аортального клапанов и аорты или с другими пороками сердца, приводящими к гибели ребёнка (летальный порок). Частота порока составляет 3-4 случая на 10000 новорожденных. При рождении дети имеют низкую массу тела, отёчный синдром, цианоз. Сердце увеличено в размерах (кардиомегалия). Этиология данного порока не известна.

\section{3. Действие тератогенов}

Внешний фактор, который может вызвать врождённый порок, нарушая нормальное эмбриональное и фетальное развитие, называется тератогеном. Потенциальные эффекты любого тератогена будут зависеть от дозы и времени воздействия на организм во время беременности, а также предрасположенности к нему матери и плода.

Химические тератогены. Вещества с доказанным тератогенным эффектом, которые обуславливают около $2 \%$ врождённых аномалий, перечислены в таблице 6. Кроме того, предполагалось, но не было доказано, тератогенное действие некоторых противораковых средств (метотрексат, хлорамбуцил), антиконвульсантов (карбамазепин). В качестве примера тератогена можно привести соединения ртути, которыми заражена рыба в Японии, в результате загрязнения окружающей среды. Употребление этой рыбы беременными вызывает у детей синдром, подобный церебральному параличу. 
Таблица 6

Вещества с доказанным тератогенным эффектом

\begin{tabular}{|l|l|}
\hline \multicolumn{1}{|c|}{ Вещество } & \multicolumn{1}{c|}{ Эффекты } \\
\hline Тетрациклин & Гипоплазия зубной эмали \\
\hline Талидомид & Фокомелия, аномалии сердца и ушных раковин \\
\hline Вальпроевая кислота & Дефекты нервной трубки, характерное лицо \\
\hline Варфарин & Гипоплазия носа, изменения эпифиза \\
\hline Алкоголь & Пороки сердца, микроцефалия, характерное лицо \\
\hline Диэтилстильбестрол & Аномалии матки, аденокарцинома влагалища \\
\hline Литий & Пороки сердца \\
\hline Фенитоин & $\begin{array}{l}\text { Пороки сердца, расщелина нёба, гипоплазия } \\
\text { пальцев }\end{array}$ \\
\hline Ретиноиды (витамин А) & Дефекты органов зрения и слуха, гидроцефалия \\
\hline Стрептомицин & Глухота \\
\hline
\end{tabular}

Примером лекарства с тератогенным действием является талидомид, который широко использовался в Европе с 1958 г. по 1962 г., как седативное средство, в том числе беременными женщинами. За такой короткий период свыше 10000 детей пострадали от этого лекарства. Критический период действия талидомида - между 20 и 35 днями от зачатия. Наиболее характерная аномалия, вызванная талидомидом, - фокомелия (порок, при котором в конечности отсутствуют некоторые или все длинные кости, но остаются пальцы, что создает вид, «подобный тюленю»). Кроме того, у детей формируются дефекты ушных раковин, микрофтальмия и расщелина губы и нёба. Почти $40 \%$ детей с этими пороками развития умирают в младенчестве в результате тяжёлых аномалий развития сердца, почек и желудочно-кишечного тракта. «Талидомидовая трагедия» сфокусировала внимание на важности противопоказаний к применению многих лекарств во время беременности, если не установлена их абсолютная безопасность. 
Чтобы избежать повторения подобной трагедии, производителями проводятся исследования лекарств до выпуска к общему применению. Кроме того, во многих странах мира созданы системы мониторинга в форме регистров врождённых аномалий развития.

Следует упомянуть также о фетальном алкогольном синдроме. У детей матерей, принимающих алкоголь во время беременности, формируются особенности лица с короткими глазными щелями, длинным сглаженным фильтром; наблюдается также задержка психического развития, гиперактивность. Данных об уровне алкоголя, безопасном для плода, нет, но даже малые его количества могут быть вредны.

Инфекции у матерей. Ряд инфекций могут нарушать эмбриональное развитие (табл. 7).

Таблица 7

Инфекции матерей, имеющие тератогенный эффект

\begin{tabular}{|l|l|}
\hline \multicolumn{1}{|c|}{ Возбудитель } & \multicolumn{1}{c|}{ Эффекты } \\
\hline Вирус простого герпеса & Микроцефалия, микрофтальмия \\
\hline Цитомегаловирус & Хориоретинит, глухота, микроцефалия \\
\hline Вирус краснухи & $\begin{array}{l}\text { Микроцефалия, катаракта, ретинит, пороки } \\
\text { сердца }\end{array}$ \\
\hline $\begin{array}{l}\text { Bирус ветряной оспы } \\
\text { (varicella zoster) }\end{array}$ & Микроцефалия, хориоретинит, дефекты кожи \\
\hline Сифилис & Гидроцефалия, остеит, ринит \\
\hline Токсоплазмоз & $\begin{array}{l}\text { Гидроцефалия, микроцефалия, катаракта, хори- } \\
\text { оретинит, глухота }\end{array}$ \\
\hline
\end{tabular}

Вирус краснухи поражает 15-25\% детей, инфицированных в первом триместре беременности, вызывая кардиоваскулярные аномалии (открытый артериальный проток, стеноз легочной артерии).

Цитомегаловирус вызывает высокий риск врождённых аномалий, если инфицирование произошло в первом триместре 
беременности. Иммунизации против цитомегаловируса нет, даже перенесённая острая инфекция не дает стойкого иммунитета.

Материнское инфицирование паразитом токсоплазмой создаёт $20 \%$-й риск инфицирования плода в первом триместре, возрастая до $75 \%$ во втором и третьем триместрах. Вакцины против токсоплазмоза не существует.

Если женщина имеет одну из этих инфекций, то необходимо установить следующее:

а) инфицирован ли плод (при исследовании крови на специфические антитела);

б) нет ли признаков генерализации инфекции в виде тромбоцитопении и нарушения функции печени.

Физические факторы. Трудно доказать тератогенное воздействие радиоволн, ультразвука и магнитных полей в силу их повсеместного распространения. Однако существуют явные доказательства того, что два физических фактора - ионизирующая радиация и длительная гипертермия могут обладать тератогенным действием.

Ионизирующая радиация - дозы гораздо большие, чем те, что используются для рентгеноскопии и рентгенографии, могут быть причиной микроцефалии и пороков развития глаз у развивающегося плода. Наиболее чувствительное время экспозиции - 2-5-я недели после зачатия. Хотя риск применения малых доз минимален, во время беременности рекомендуется избегать радиографии.

Длительная гипертермия - на ранних сроках беременности может вызвать микроцефалию, микрофтальмию и нарушения нейрональной миграции. Следовательно, необходимо избегать перегревания в первом триместре беременности.

Болезни матерей. Многие заболевания матери связаны с повышенным риском неблагоприятного исхода беременности, некоторые из них представлены ниже.

Инсулинзависимый сахарный диабет у беременных женщин приводит к 2-3-кратному повышению количества врождённых аномалий у их потомства. Наиболее частыми пороками развития среди них являются врождённые пороки сердца, дефекты нервной 
трубки, агенезия крестца, гипоплазия бедер, голопрозенцефалия и сирингомиелия (аномалия спинного мозга в виде образования полостей в сером веществе). Вероятность врождённых аномалий зависит от уровня глюкозы и гликозилированного гемоглобина в крови беременной. Инсулиннезависимый диабет и гестационный диабет у матери не ведут к повышению риска аномалий у потомства.

Фенилкетонурия. Матери с высоким уровнем фенилаланина в крови имеют высокий риск врождённых аномалий у потомства: умственная отсталость наблюдается почти в $100 \%$ случаев; могут встречаться микроцефалия и пороки сердца. Все женщины с фенилкетонурией должны соблюдать строгую диету с низким содержанием фенилаланина, концентрация в крови которого должна мониторироваться.

Эпилепсия у матери сама по себе не приводит к возникновению врождённых аномалий у детей. Однако большинство исследований указывает на повышенную частоту пороков развития у детей, матери которых принимали антиконвульсанты (противоэпилептические препараты) во время беременности. Риск врождённых аномалий у таких детей в 2-4 раза выше общепопуляционного. Эти данные касаются монотерапии, при использовании же двух и более препаратов риск удваивается. Наибольшим тератогенным эффектом обладает вальпроат натрия. Аномалии, встречающиеся у больных, подвергшихся экспозиции антиконвульсантов во время своего внутриутробного развития, широко варьируют и встречаются в виде дефектов нервной трубки, расщепления губы и нёба, аномалий мочеполовой системы (в частности, гипоспадии), пороков сердца и дефектов конечностей. Эти аномалии неспецифичны, что затрудняет диагностику, однако дети с фетальным вальпроатным синдромом имеют типичное лицо (широкое основание носа, широкий плоский его кончик, тонкая верхняя губа). Если женщине нельзя отменить антиконвульсанты во время беременности, то следует использовать только один лекарственный препарат и избегать при этом вальпроата натрия. В более чем половине случаев врождённых аномалий развития не удается установить причину их возникновения. Это 
касается таких частых состояний, как диафрагмальная грыжа, трахео-эзофагальная фистула, атрезия ануса и др. Чтобы предполагать генетическую природу врождённых пороков развития, полезно оценивать их симметричность. Симметричные и затрагивающие срединные структуры аномалии чаще имеют генетическую основу, в то время как для асимметричных она менее вероятна. Например, явная асимметрия конечностей имеет, как правило, негенетическую природу и часто связана с нарушением кровообращения конечности в ходе ее развития.

Таким образом, в формировании врождённых аномалий значительную роль играют тератогенные факторы окружающей среды.

\section{Гдава 7. МЕТОДЫ ИЗУЧЕНИЯ ГЕНОМА ЧЕЯОВЕКА}

Основная цель большинства исследований в области генетики человека заключается в выявлении изменений последовательности ДНК, которые являются причиной нарушений в жизнедеятельности организма. Далее исследователи, как правило, пытаются установить причинно-следственную связь между мутациями и их вероятными фенотипическими последствиями с помощью определения биохимических процессов, связанных с изменением функциональной активности генома. Наиболее общая классификация методов изучения генома человека может быть сделана на базе двух основных типов мутаций: генных и хромосомных (геномных). Таким образом, выделяют два основных направления исследования генетических нарушений: молекулярно-генетическое и цитогенетическое (молекулярно-цитогенетическое). В последнее десятилетие молекулярно-цитогенетические исследования с помощью методов флюоресцентной и сравнительной геномной гибридизации in situ (FISH, MCB, HR CGH), а также серийной сравнительной геномной гибридизации (arrayCGH или молекулярное кариотипирование) можно выделить отдельным направлением, поскольку оно занимает значительное место в изучении и диагностике геномных нарушений ввиду разрешающих способностей применяемых методов (от 1 тысячи пн и более). Разрешающая способность методов представлена в таблице 8. 
Таблица 8

\section{Разрешающая способность цитогенетических и молекулярно-цитогенетических методов}

\begin{tabular}{|c|c|c|}
\hline Метод & Краткое описание & $\begin{array}{l}\text { Разрешаю- } \\
\text { щая способ- } \\
\text { ность (пары } \\
\text { нуклеоти- } \\
\text { дов - пн) }\end{array}$ \\
\hline $\begin{array}{l}\text { Цитогенетиче- } \\
\text { ский метод }\end{array}$ & $\begin{array}{l}\text { Культивирование клеток и последующее } \\
\text { дифференциальное окрашивание мета- } \\
\text { фазных хромосом по длине }\end{array}$ & 5-8 млн \\
\hline FISH & $\begin{array}{l}\text { Флюоресцентная гибридизация in situ } \\
\text { с использованием ДНК зондов на опре- } \\
\text { деленные участки генома, высокоповто- } \\
\text { ряющиеся последовательности и пробы, } \\
\text { маркирующие полностью хромосому }\end{array}$ & $\begin{array}{l}\text { от } 500-5000 \\
\text { до } 3 \text { млн }\end{array}$ \\
\hline $\begin{array}{l}\text { Классическая } \\
\text { метафаз- } \\
\text { ная CGH - } \\
\text { HR CGH }\end{array}$ & $\begin{array}{l}\text { CGH с использованием смеси меченых } \\
\text { геномной ДНК пациента и ДНК донора }\end{array}$ & $1,5-10$ млн \\
\hline $\begin{array}{l}\text { Серийная CGH } \\
\text { (arrayCGH) }\end{array}$ & $\begin{array}{l}\text { CGH на чипах с использованием смеси } \\
\text { меченых геномной ДНК пациента и ДНК } \\
\text { контроля }\end{array}$ & $\begin{array}{l}\text { от } 1 \text { тысячи } \\
\text { до } 1 \mathrm{млн}\end{array}$ \\
\hline $\begin{array}{l}\text { Олигонуклео- } \\
\text { тидная серий- } \\
\text { ная CGH }\end{array}$ & $\begin{array}{l}\text { CGH с использованием смеси меченых } \\
\text { геномной ДНК пациента и небольших } \\
\text { последовательностей ДНК (олигонукле- } \\
\text { отидов) }\end{array}$ & $\begin{array}{c}\text { около } \\
50 \text { тысяч }\end{array}$ \\
\hline
\end{tabular}

\section{1. Молекулярно-генетические методы}

Поиск изменений последовательностей нуклеиновых кислот и белков на молекулярном уровне является одним из основных направлений молекулярной генетики. Выявление мутационных изменений ДНК при наследственных заболеваниях и полном отсутствии знания о патогенезе заболевания происходит с помощью молекулярно-генетических методов следующим образом: 
на первом этапе осуществляется сканирование генома для поиска каких-либо отклонений или соответствующих маркеров. Это проделывается на базе анализа сегрегации болезни в семьях больных, а также поиска аллелей, потенциально связанных с заболеванием, среди больших групп неродственных больных. Далее, выделяются некоторые гень-кандидаты, в которых с высокой долей вероятности могут наблюдаться мутации, связанные с исследуемым заболеванием. Однако, при наличии предположений или некоторых доказательств относительно механизмов, лежащих в основе патогенеза заболевания, первый этап молекулярно-генетических исследований, как правило, опускается.

Наиболее известными молекулярно-генетическими методами для поиска генов, потенциально связанных с конкретной болезнью, являются методы анализа сцепления и аллельной ассоциации. Оба метода преследуют цель картирования генов, аномалии которых приводят к болезни, и основаны на анализе полиморфных генетических маркеров для молекулярного сканирования генома. Эти два метода позволяют проводить молекулярно-генетические исследования в условиях отсутствия знаний о процессах, лежащих в основе патогенеза болезни. Исследование с помощью анализа сцепления требует большого числа индивидуумов из семей с соответствующими больными, в противном случае, полученные данные не будут статистически достоверными. При анализе сцепления исследуются полиморфные маркеры с известной локализацией на хромосоме (расположенные в определенных локусах), которые могут наследоваться вместе с болезнью. Если наблюдается совместное наследование (сцепление) болезни и определенных полиморфных маркеров, можно говорить о картировании генов болезни. Картирование представляет собой процесс ассоциации болезни с определенным хромосомным локусом в геноме человека. При аллельных ассоциациях изучается совместное наследование аллелей и заболевания в репрезентативных выборках неродственных больных. Если частота определенных комбинаций аллелей у больных превышает значение в контрольной группе, можно с определенной долей вероятности утверждать то, что в хромосомном (геномном) участке этого аллеля расположен ген, 
связанный с исследуемой болезнью. Анализ аллельных ассоциаций может указать на генетические факторы патогенеза или предрасположенности к заболеванию.

Существует множество методических подходов к определению генов болезни на базе данных анализа сцепления или аллельных ассоциаций. Среди них распространенным методом для определения генов, связанных с заболеванием, является выбор наиболее вероятных генов-кандидатов, локализованных в картированном участке, с последующим определением последовательности ДНК этих генов. Такой подход к исследованию оказался эффективным при идентификации генов болезни Альцгеймера, но, например, при шизофрении, аффективных расстройствах и аутизме, этот метод по большей части не дает воспроизводимых результатов. Следует отметить, что классические молекулярно-генетические методы были преимущественно разработаны для системы «один ген - одна болезнь». Это позволяет некоторым исследователям оспаривать результаты многих анализов сцепления и аллельных ассоциаций мультифакторных психических болезней (шизофрения, аутизм и др.). В связи с этим, наиболее подходящим для подобных исследований следует рассматривать анализ всего генома, при котором используются от нескольких сотен до нескольких тысяч полиморфных генетических маркеров.

Существует достаточно большое количество молекулярно-генетических методов, которые имеют широкий спектр применения. Однако многие из них являются либо модификацией, либо комбинацией нескольких основных методов. Среди последних следует выделить полимеразную цепную реакцию (ПЦР) и секвенирование (определение последовательности полимерных макромолекул).

Многие учёные используют в своей работе ПЦР как современный молекулярно-генетический метод. Этот метод позволяет определять небольшие фрагменты последовательностей ДНК. ОН также относительно несложен в исполнении и не требует значительных затрат как при адаптации к имеющимся лабораторным условиям, так и в ходе его дальнейшего использования. Классический вариант ПЦР представляет собой искусственную экспоненциальную репликацию или амплификацию небольших фрагментов 
ДНК, в среднем от 200 до 1000 пн. Для использования ПЦР необходимо знать определенную часть исследуемой последовательности ДНК, поскольку для инициации реакции применяются синтетические олигонуклеотиды (как правило, размером около 20 пн) или праймеры. ПЦР для амплификации одного фрагмента ДНК требует использования не менее 2-х праймеров: один - идентичный прямой 5' последовательности, второй идентичный обратной 5' последовательности. Геномная ДНК смешивается с праймерами и ферментом температуроустойчивой ДНК полимеразы и единичными нуклеотидами (А, Г, Ц и Т), которые являются основой для синтеза новых коротких последовательностей. Смесь нагревается для того, чтобы образовались однонитевые последовательности ДНК (прощесс денатуращии). Затем, при снижении температуры праймеры связываются с образованными последовательностями, и начинается полимеризация ДНК от 3' конца на базе единичных нуклеотидов, находящихся в смеси. Данный искусственный процесс не слишком отличается от репликации молекул ДНК в клетке за исключением того, что он происходит с короткими последовательностями. Процесс повторяется много раз, результатом чего является экспоненциальное увеличение концентрации исследуемого фрагмента ДНК по отношению к остальным последовательностям геномной ДНК. Классическая ПЦР может быть использована для получения фрагментов ДНК, которые далее можно исследовать с помощью секвенирования, а также оценить их размеры с помощью метода электрофореза. Последний основан на разделении (в зависимости от размера последовательностей) макромолекул, помещенных в гель, который находится в электрическом поле. Помимо этого, имеются также возможности для количественного определения содержания последовательностей нуклеиновых кислот в реальном времени (ПЦР в реальном времени) или по сравнению с другими последовательностями. При некоторых методах необходимо использовать предварительную обработку ДНК с последующей амплификацией для выявления изменения последовательности в исследуемом фрагменте. ПЦР может быть также использована для исследования молекул РНК. 
Секвенирование позволяет определить нуклеотидную последовательность ДНК. В связи с этим данный метод активно применяется для выявления генных мутаций при моногенных заболеваниях. Наиболее используемый вариант секвенирования известен также как метод Сэнджера. Как правило, перед секвенированием проводят ПЦР с целью увеличения концентрации ДНК фрагмента, последовательность которого необходимо определить. Далее, к однонитевой (денатурированной) молекуле ДНК присоединяются прямой и обратный праймеры, и с помощью ДНК полимеразы проводят синтез «новой» молекулы ДНК на базе дидезоксинуклеозидтрифосфатов и немодифицированных единичных нуклеотидов. В классическом протоколе секвенирования с помощью этого метода предлагается проводить 4 реакции, в каждой из которых реакционная смесь содержит три немодифицированных нуклеотида и один дидезоксинуклеозидтрифосфат. Поскольку полимеризация ДНК будет каждый раз заканчиваться на дидезоксинуклеозидтрифосфате, то в каждой смеси будут находиться фрагменты разных размеров, соответствующие исследуемой последовательности, оборванной на нуклеотиде, замещённом дидезоксинуклеозидтрифосфатом. Затем результаты 4-х реакций анализируются с помощью электрофореза; складывая их, восстанавливается исходная последовательность ДНК. В настоящее время, благодаря созданию высокоразрешающих систем детекции, для секвенирования используются другие способы проведения реакции и анализа конечных результатов. Однако принцип метода остается прежним.

В связи с тем, что при многих наследственных заболеваниях патогенные мутации (в основном, рекуррентные) уже известны, отпадает необходимость использования метода секвенирования для их определения. В данном случае наиболее рационально применение рестрикционного анализа с последующей ПЦР. При этом методе используется способность некоторых ферментов (эндонуклеаз рестрикции или рестриктаз) «разрезать» фрагменты ДНК в зависимости от их последовательности в специфических сайтах. Этот процесс также называется рестрикцией. Для проведения данного анализа ДНК необходимо знать изменение последовательности, чтобы подобрать соответствующую рестриктазу. 
На первой стадии этого метода проводится рестрикция ДНК, а затем ПЦР фрагмента ДНК, в котором предположительно расположена мутация. Результаты ПЦР также анализируются с помощью электрофореза. В основном, используются такие рестриктазы, которые при условии наличия мутации взаимодействуют с ДНК, образуя два фрагмента различных размеров. Возможен также вариант, когда рестриктазы взаимодействуют с неизмененной последовательностью ДНК, тогда как при мутации рестрикции не происходит (рис. 18).

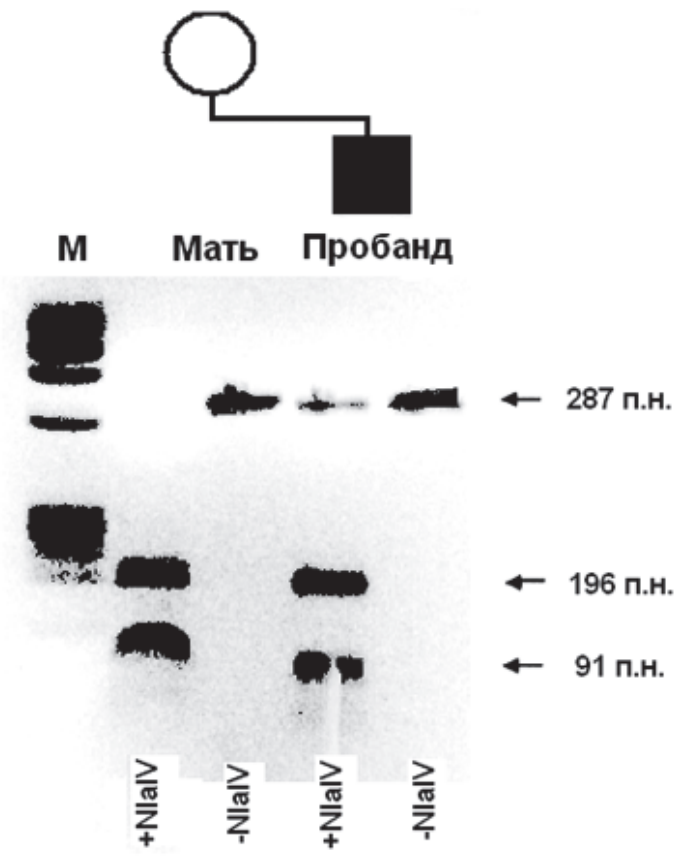

Рис. 18. Результаты рестрикционного анализа с последующей ПЦР мутации R270X в гене $M E C P 2$ у пробанда с синдромом Ретта и его матери. Взаимодействие ДНК с рестриктазой NlaIV (+NlaIV) показывает наличие мутации у ребенка - дополнительная полоса, соответствующая апмлифицированному участку, необработанному рестриктазой (-NlaIV). У матери в данном случае мутации не обнаружено (М - маркер молекулярного веса для определения размера последовательности ДНК) 
В ряде случаев возникает необходимость сравнительного анализа содержания фрагментов ДНК. С помощью подобных методов, в основном, исследуют полиморфные последовательности, которые с высокой вероятностью будут отличаться в зависимости от родительского происхождения. Они используются для определения родительского происхождения и диагностики однородительской дисомии, потери/приобретения последовательностей ДНК, а также Х-инактивации при условии предварительной обработки веществами, чувствительными к метилцитозину. Наиболее востребованным для этой цели методом является количественная ПЦР. Данная модификация использует мечение одного из праймеров, благодаря чему амплифицированный участок также становится меченым. Затем, с помощью различных систем детекции можно провести сравнительный количественный анализ ДНК фрагментов одного или нескольких аллелей.

\section{2. Цитогенетические и молекулярно-цитогенетические методы}

Среди наиболее распространенных мутаций у человека являются хромосомные. Показано, что хромосомная патология составляет $30 \%$ от общего числа пороков развития у новорожденных, до 45-70\% всех случаев спонтанных абортов (до 15-й недели беременности) и 6-7\% мертворожденных детей этиологически связаны с хромосомными аномалиями. Среди недоношенных детей частота хромосомных аномалий достигает 7:1000. Причем, среди недоношенных детей с врождёнными пороками развития уровень хромосомных аномалий достигает $18 \%$, а при наличии комплексных врождённых пороков - более $45 \%$. В среднем аномалии кариотипа встречаются у $15 \%$ детей с недифференцированными формами умственной отсталости, врождёнными пороками и/или микроаномалиями развития. Поэтому, неудивительно, что особое место в медицинской генетике занимают методы их выявления (цитогенетические и молекулярно-цитогенетические), разрешающая способность которых различна (табл. 8). 


\subsection{1. Цитогенетические методы}

Диагностика хромосомных аномалий проводится с использованием цитогенетических методов, которые включают в себя культивирование с целью получения метафазных клеток с последующим применением дифференциального окрашивания хромосом по длине и исследованием кариотипа с помощью светового микроскопа. Данный комплекс приемов получил широкое распространение в связи с тем, что в течение долгих лет он представлял собой практически единственный способ идентификации хромосомных аномалий. Существует несколько типов дифференциального окрашивания хромосом по длине. Они определяют единую линейную дифференциацию структуры хромосом в метафазе митоза, при этом каждый метод окрашивания имеет свои характерные особенности, и существует в нескольких модификациях. Следует отметить, что они не являются альтернативными. Наиболее распространенным методом дифференциального окрашивания хромосом является $\boldsymbol{G}$-окрашивание. Этот метод базируется на предварительной обработке препаратов хромосом перед окраской и на использовании нефлюоресцентных красителей или их смесей. Предварительная обработка связана с инкубацией в солевых растворах и в растворах протеолитических ферментов (взаимодействующих, по-видимому, с белковой компонентой хроматина). Идентификацию хромосом обеспечивает чередование темно и светло окрашенных полос. По числу, величине и расположению полос (сегментов) можно определить изменения в хромосомном наборе (кариотипе). Число полос на гаплоидный кариотип при G-окрашивании варьирует, но в метафазной клетке их число не менее 320 , а на стадии прометафазы может достигать и 1250 полос. Существуют также и методы, которые окрашивают определённые участки хромосом (например, $\boldsymbol{C}$-окрашивание, с помощью которого анализируются гетерохроматиновые участки). Применение С-метода также необходимо при идентификации хромосомных аномалий или дифференциации между хромосомными мутациями и морфологическими особенностями хромосом. Однако в ряде случаев применение цитогенетического анализа метафазных хромосом бывает затруднено или 
невозможно (сложность культивирования клеток большинства соматических тканей; диагностика хромосомных микроаберраций). Следует напомнить, что разрешающая способность этого метода - 5-7 млн пн.

С развитием медицинской генетики и совершенствованием микроскопической техники был разработан целый ряд новых технологий, основанных на принципах гибридизации нуклеиновых кислот на препарате, применение которых позволило в значительной степени увеличить эффективность выявления хромосомных аномалий, а в ряде случаев дополнить или заменить цитогенетический анализ определенным молекулярно-цитогенетическим методом. Использование соответствующего молекулярно-цитогенетического метода зависит от разрешающей способности технологии. Биомедицинское направление, целью которого явилось изучение хромосом с помощью последних достижений в области молекулярной биологии, сформировалось как наука и получило название молекулярная цитогенетика.

\subsection{2. Молекулярно-цитогенетические методы}

Среди самых распространенных молекулярно-цитогенетических методов известны: флюоресцентная гибридизация in situ (fluorescence in situ hybridization - FISH) и сравнительная геномная гибридизация (comparative genomic hybridization - CGH). Как несложно заметить, оба эти метода основаны на процессе гибридизации нуклеиновых кислот. Гибридизация in situ основана на взаимодействии однонитевых последовательностей экзогенной ДНК, меченной флюорохромами (флюоресцирующими веществами) - ДНК пробы, и исследуемой ДНК. Разрешающая способность молекулярно-цитогенетических методов определяется минимальным размером последовательности хромосомной ДНК (количеством нуклеотидов), которую возможно регистрировать с помощью микроскопа или другой системы детекции. В качестве стандарта при молекулярно-цитогенетическом анализе используются цитогенетические методы.

Схема проведения FISH представлена на рисунке 19. Первой стадией FISH является денатурация - процесс получения однонитевых 
последовательностей ДНК. Следующей стадией является гибридизация - реакция воссоединения однонитевых последовательностей ДНК зонда и ДНК, находящейся на цитологическом препарате в составе метафазных хромосом и интерфазных ядер, с образованием двунитевых молекул ДНК. В результате появляется возможность анализа флюоресцирующих последовательностей ДНК на предметном стекле с помощью флюоресцентного микроскопа.

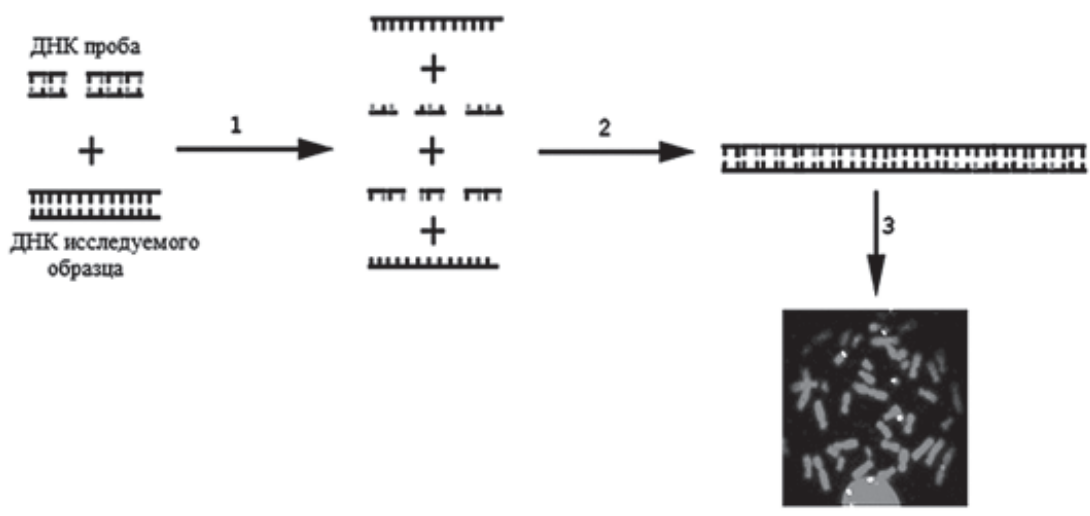

Рис. 19. Схематическое изображение метода FISH:

1 - смесь ДНК пробы и ДНК исследуемого образца денатурируется при температуре $72-75^{\circ} \mathrm{C}$, в результате чего получается смесь однонитевых последовательностей ДНК;

2 - гибридизация ДНК пробы и исследуемого образца: меченая ДНК проба встраивается в ДНК исследуемого образца на препарате хромосом; 3 - детекция меченой ДНК in situ с помощью флюоресцентного микроскопа

Идентичный принцип лежит также в основе метода HR CGH, схема которого представлена на рисунке 20. Отличие заключается лишь в том, что в случае CGH гибридизация на хромосомах in situ проводится с использованием смеси меченых одним флюорохромом геномной ДНК пациента и другим флюорохромом ДНК донора (при исследовании численных хромосомных аномалий) или геномной ДНК пациента и ДНК какой-то конкретной хромосомы донора (при исследовании структурных хромосомных аномалий). Затем с помощью цифрового анализа 
производится сравнительная оценка интенсивности суперпозиции сигналов двух разных флюорохромов, в результате чего становится возможным определение приобретения или потери последовательностей ДНК у пациента в строго определенных хромосомах. На рисунке 21 показан результат проведения классической метафазной сравнительной геномной гибридизации (HR CGH) ребёнку с умственной отсталостью и МАР.

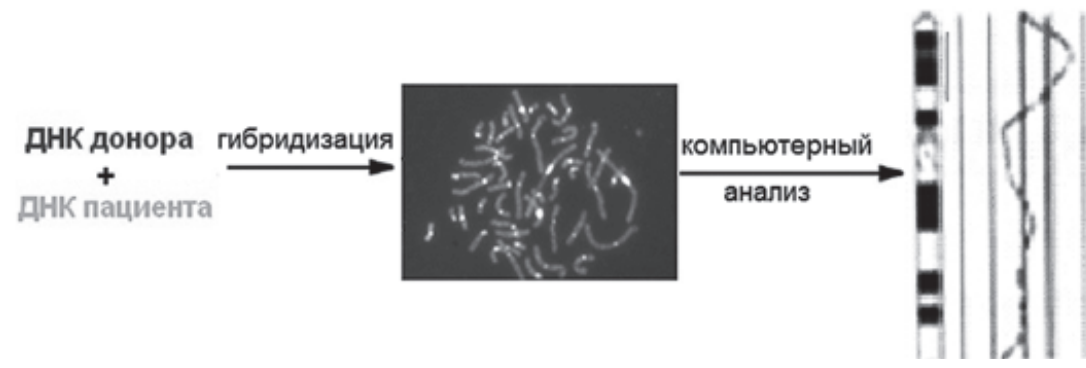

Рис. 20. Схематическое изображение метода классической CGH на метафазных хромосомах: гибридизация двух меченых разными красителями образцов тотальной ДНК (пациента и донора) происходит так, как и в случае FISH. Затем, соотношение интенсивностей результатов гибридизации ДНК пациента и донора на метафазных хромосомах анализируется с помощью компьютера. Соотношение 1:1 соответствует норме; 1 (донор):0,5 (пациент) - делеции; 1 (донор):1,5 (пациент) - дупликации

В настоящее время известен целый комплекс модификаций FISH. Практически все разновидности метода FISH являются взаимодополняющими при диагностике хромосомных аномалий, поскольку существует достаточно большое количество флюорохромов с различными свойствами. Имеется возможность детекции множества последовательностей ДНК на цитологическом препарате за счет того, что каждая из ДНК проб будет мечена определенным цветом (многоцветовая FISH или MFISH). Тем не менее, одноцветовая FISH является одним из основных среди всех молекулярно-цитогенетических методов. Спектр применения данного метода в значительной степени широк: от диагностики самых распространенных численных хромосомных аномалий (например, 
синдром Дауна и его мозаичные формы) до идентификации редких структурных хромосомных перестроек при недифференцированных формах наследственной патологии. Особое внимание заслуживает одноцветовая FISH с использованием ДНК проб, маркирующих полностью пару гомологичных хромосом. Этот метод применяется преимущественно для идентификации сложных хромосомных перестроек, реже он используется для определения численных хромосомных аномалий.

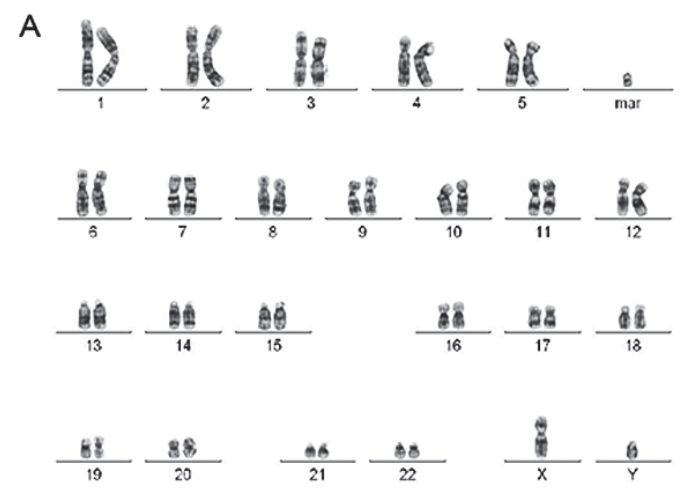

Хромосома
Б

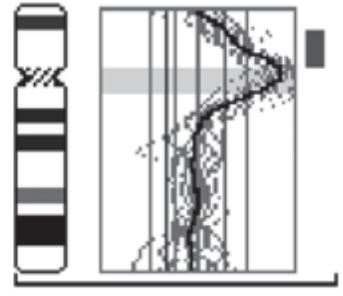

18

Рис. 21. Результаты проведения HR CGH ребенку с умственной отсталостью и МАР:

A - цитогенетическое исследование [кариотип: 47,XY,+mar]; Б - молекулярно-цитогенетическое исследование: обнаружено увеличение числа копий последовательностей ДНК (трипликация) короткого плеча хромосомы 18 [ish cgh enh(18)(p11.1pter)*].

*запись результата в соответствии с международной номенклатурой ISCN 2013

MFISH основывается на создании смеси ДНК проб, меченных различными флюорохромами, которые одновременно вводятся в исследуемый препарат с последующей совместной гибридизацией. Изначально данный метод разрабатывался для идентификации хромосомных аномалий при отсутствии клинического диагноза из-за значительной экономии затрачиваемого экспериментального времени на анализ. Помимо этого, данный метод является эффективным 
для определения структурных хромосомных аномалий за счет одновременной визуализации нескольких участков хромосом. На базе ранних разработок MFISH были созданы такие высокоразрешающие методы идентификации хромосомных аномалий, как 24-цветовая FISH и спектральное кариотипирование (SKY - spectral karyotyping). Данные методы используют комбинацию из 24-х ДНК проб, меченных разными флюорохромами, которые соответствуют каждой гомологичной аутосоме и половым хромосомам. Различие их заключается в том, что для SKY используются специальные спектральные системы детекции, а для 24-цветовой FISH применяется цифровой анализ изображения, целью которого является создание соответствующей комбинации цветов, в результате чего каждая хромосома имеет свою характерную окраску. Использование технологий, основанных на микроманипуляции микроскопическими объектами, позволило создать коллекцию ДНК проб, маркирующих одновременно участки хромосом, соответствующие полосам G-окрашивания. Подобные коллекции обычно состоят из нескольких сотен проб и их применение позволяет получить разноцветное сегментное окрашивание всех хромосом с высоким разрешением. МCB FISH (multicolor banding FISH) представляет собой высокоэффективный метод диагностики сложных структурных хромосомных перестроек и микроаберраций.

В настоящее время существует целый ряд модификаций CGH, применение которых рассматривается в качестве оправданных при ряде диагностических процедур. Как уже было сказано, применение методов зависит от их разрешающей способности, оценивающейся числом последовательностей ДНК, которая представлена в таблице 8. Классический CGH анализ был внедрен в молекулярно-цитогенетическую практику для анализа хромосомного набора в клетках тканей, культивирование которых затруднено или невозможно. Среди основных ограничений CGH необходимо отметить невозможность диагностики хромосомного мозаицизма и сбалансированных структурных хромосомных перестроек. Разработка и модификации метода CGH была направлена на создание протоколов для высокоразрешающей идентификации хромосомных микроаберраций (микроделеций и микродупликаций). В результате этого были созданы методы серийного СGH анализа (серийная 
CGH или arrayCGH). Серийный CGH анализ основан не на гибридизации тотальной геномной ДНК донора и пациента, а на применении в качестве ДНК донора специфических последовательностей ДНК (наночип), соответствующих определенным участкам хромосом. Схема проведения arrayCGH (молекулярного кариотипирования) представлена на рисунке 22. CGH проводится несколькими сериями с использованием цифровых систем детекции и анализа сравнительной интенсивности сигналов. Методы, основанные на серийной $\mathrm{CGH}$, позволяют проводить идентификацию хромосомных микроаберраций, а также генных мутаций, затрагивающих последовательности ДНК, размер которых больше 50 пн. На рисунках 23, 24, 25 и 26 показаны результаты проведения arrayCGH детям с различными геномными аномалиями: дополнительным материалом на хромосоме 1 (рис. 23), дополнительным материалом на хромосоме 13 (рис. 24), дополнительным материалом на хромосоме X (рис. 25) и кольцевой хромосомой 11 (рис. 26).

Одним из наиболее используемых методов молекулярно-цитогенетической диагностики является интерфазная FISH на препаратах культивированных и некультивированных клеток. Данный метод нашел широкое применение в идентификации хромосомных аномалий при различных заболеваниях, многие из которых сопровождаются нарушением психики. Среди преимуществ данного метода следует отметить высокую эффективность определения регулярных и мозаичных форм фактически любой хромосомной патологии. Дополнительным преимуществом этого метода является возможность проведения анализа непосредственно на предметном стекле, которое можно было использовать при классическом цитогенетическом анализе (культивирование клеток исследуемой ткани, дифференциальное окрашивание хромосом, исследование кариотипа с помощью светового микроскопа). Однако невозможность культивирования большинства клеток тканей человека ограничивает FISH анализ на метафазных хромосомах. В результате чего был разработан метод FISH на интерфазных ядрах или интерфазная FISH. Этот метод также в значительной степени более эффективен по сравнению с FISH анализом метафазных хромосом при идентификации мозаичных форм численных 
хромосомных аномалий, поскольку позволяет легко изучить большое число клеток (до нескольких десятков тысяч). Недостатком этого метода является сложность в определении структурных хромосомных аномалий. На рисунке 27 показан пример использования метода FISH на интерфазных клетках.

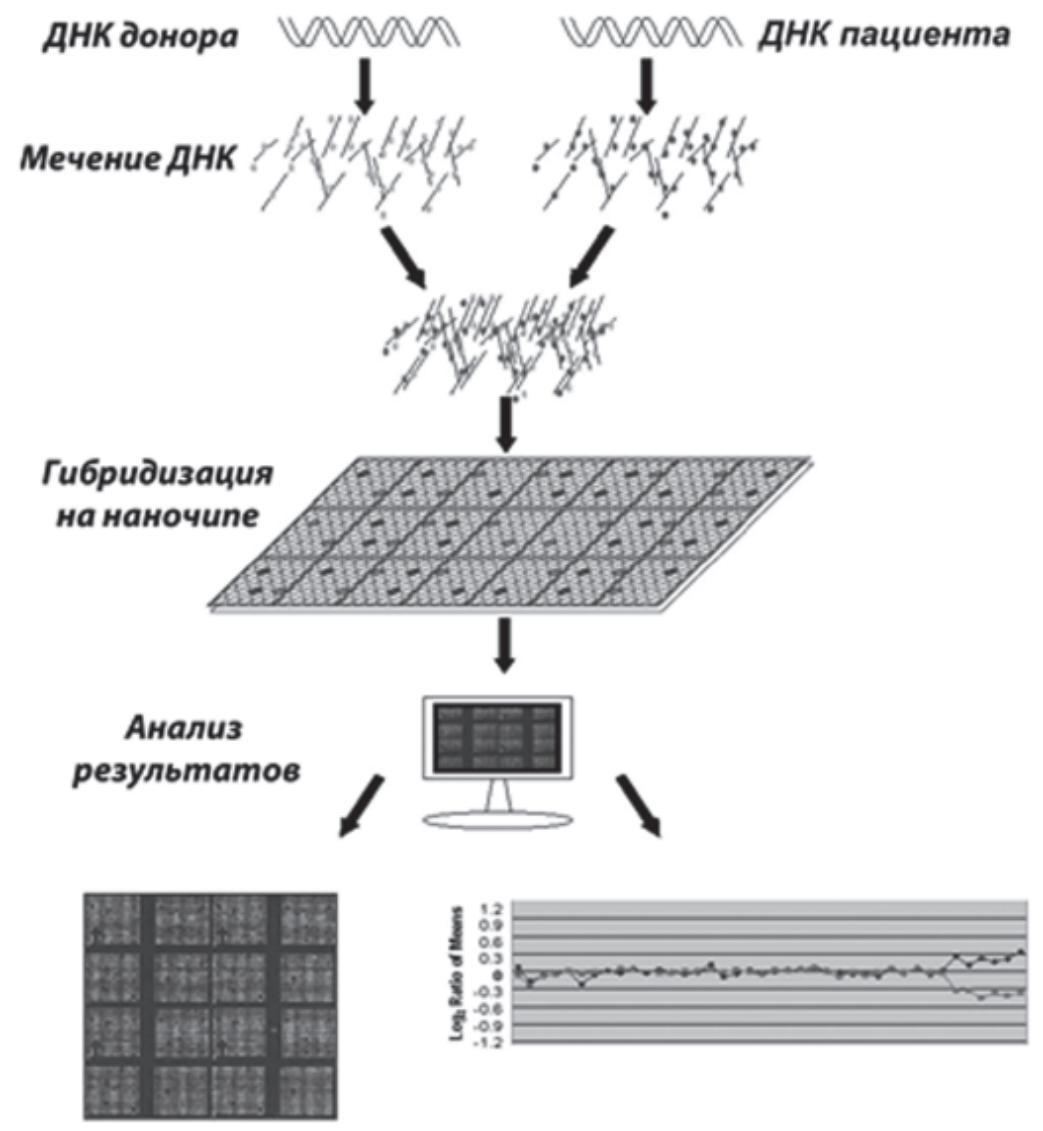

Рис. 22. Схематическое изображение метода arrayCGH: ДНК пациента и донора метятся разными флюорохромами; затем проводится гибридизация на наночипе, далее результаты сканируются и анализируются с помощью специальных систем «лазерный сканер + компьютер» 

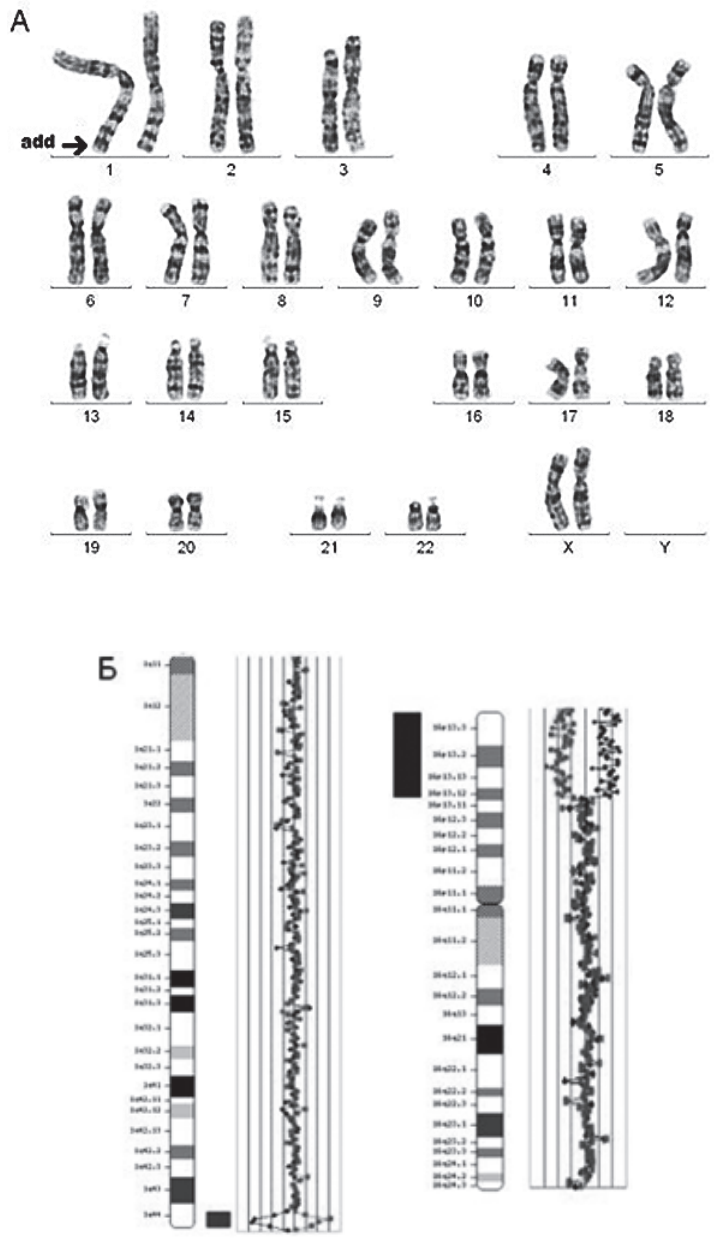

Хромосомы

1

16

Рис. 23. Результаты молекулярно-цитогенетического исследования дополнительного материала неизвестного происхождения на длинном плече хромосомы 1:

А - цитогенетический анализ [кариотип ребёнка: 46,XX, add(1)(q4?4)];

Б - исследование методом arrayCGH участка длинного плеча хромосомы 1 и хромосомы 16.

Обнаружены делеция длинного плеча хромосомы 1 (размер 2825742 пн) и дупликация короткого плеча хромосомы 16 (размер 14443283 пн) 

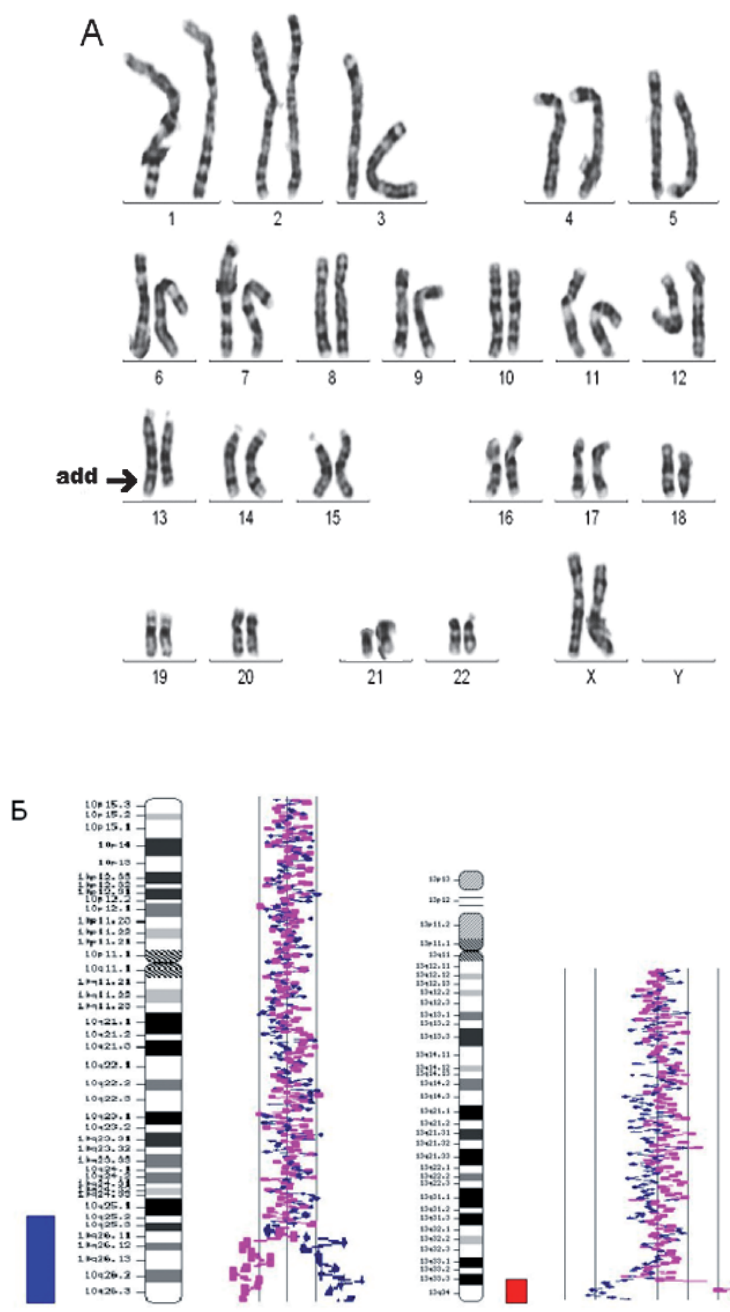

Хромосомы

10

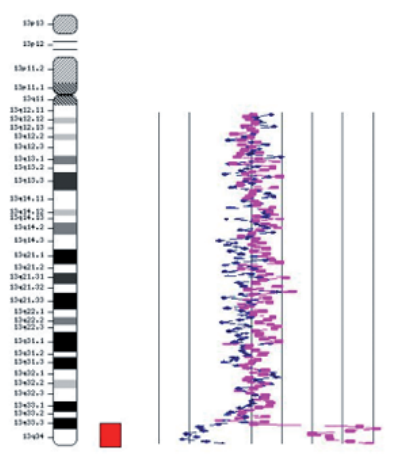

13

Рис. 24. Результаты исследования дополнительного материала на длинном плече хромосомы 13:

A - цитогенетический анализ [кариотип ребёнка: 46,XX, add(13)(q33)];

Б - исследование методом arrayCGH хромосомы 10 и 13.

Обнаружена дупликация длинного плеча хромосомы 10 (размер 23108414 пн) и делеция длинного плеча хромосомы 13 (размер 5720171 пн) 

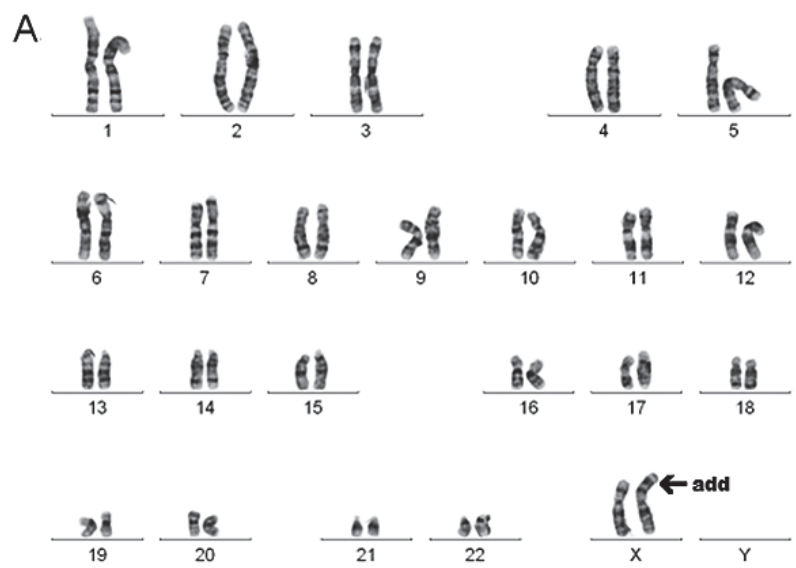

Б

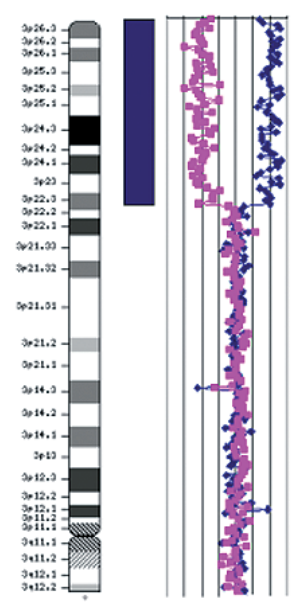

3
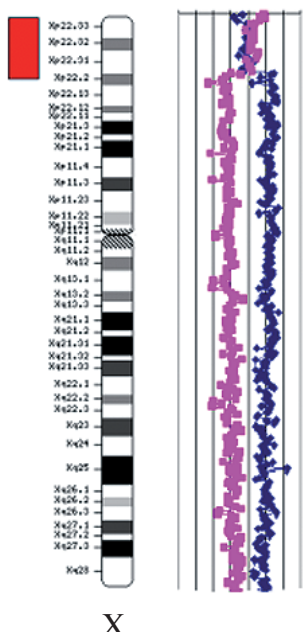

Хромосомы

Рис. 25. Результаты исследования дополнительного хромосомного материала на коротком плече хромосомы X:

A - цитогенетический анализ [кариотип: 46,X, add(X)(?::p?22qter), 16qh-]; Б - исследование методом arrayCGH коротких плеч хромосомы 3 и хромосомы X.

Обнаружена дупликация короткого плеча хромосомы 3 (размер 36350871 пн) и делеция короткого плеча хромосомы X (размер 7392677 пн) 

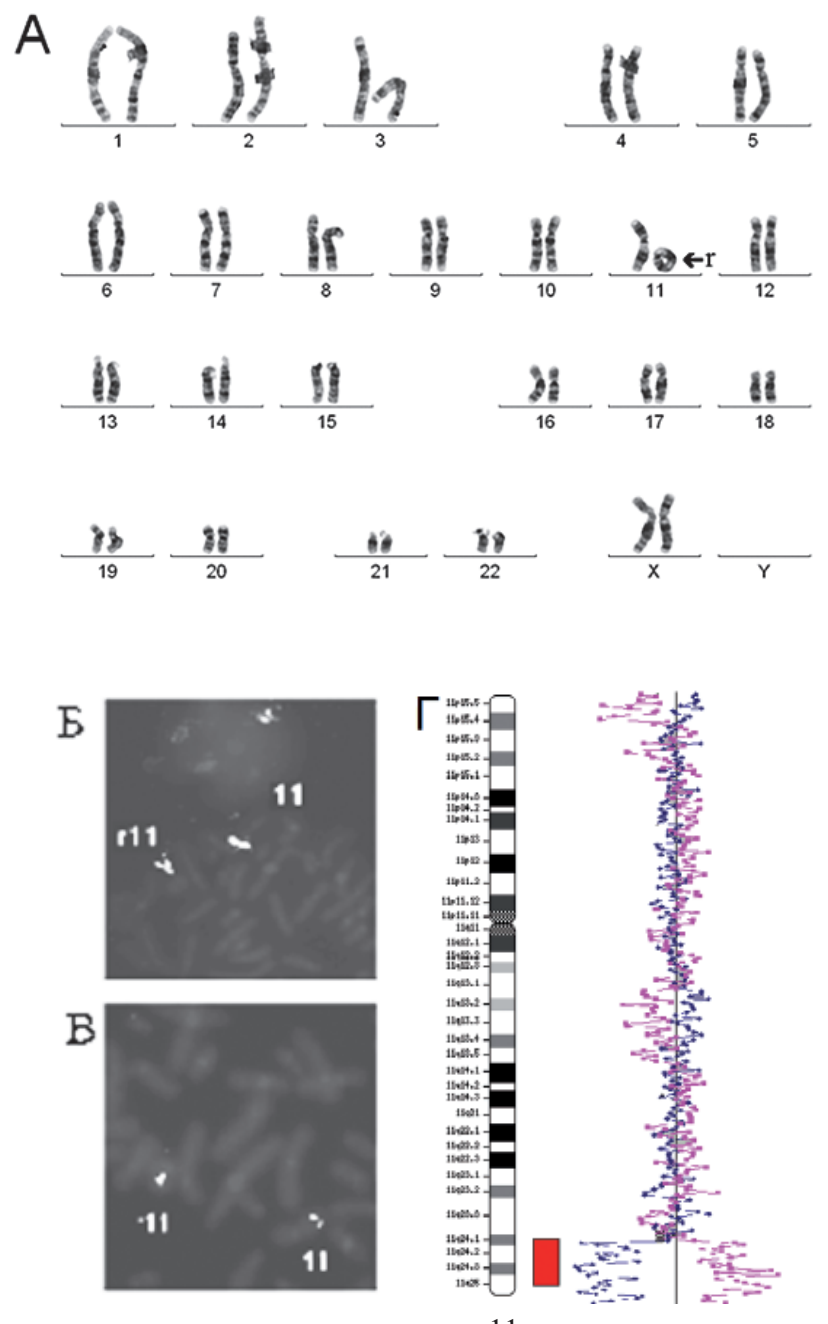

Хромосома

11

Рис. 26. Результаты исследования кольцевой хромосомой 11:

А - цитогенетический анализ [кариотип: 46,XX,r(11)(p15.?5q23.?3)];

Б, В - использование метода FISH с ДНК пробами на различные участки длинного плеча хромосомы 11;

Г - исследование хромосомы 11 методом arrayCGH. Обнаружена делеция длинного плеча хромосомы 11 (размер 13505195 пн) 


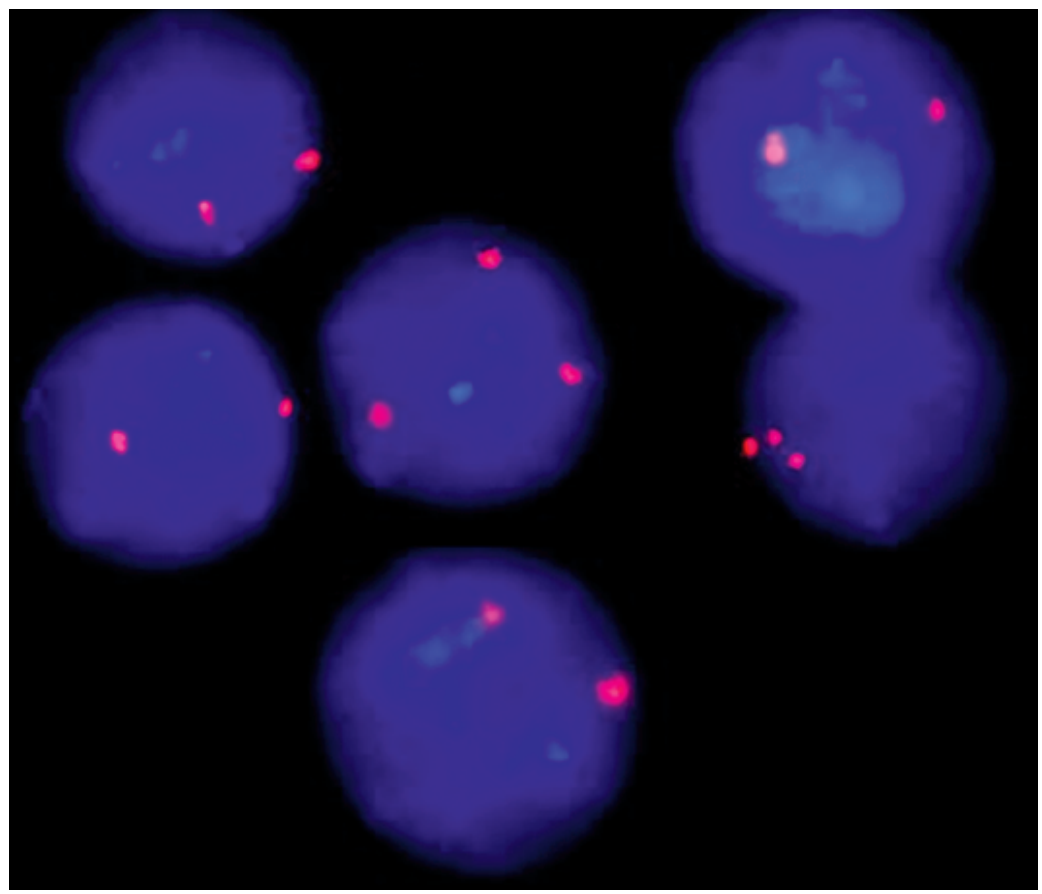

Рис. 27. Пример использования метода FISH, демонстрирующий наличие двух хромосом Х в клетке (норма) и трёх хромосом Х (трисомия хромосомы X). Видны: три сигнала в клеточном ядре, соответствующие трём хромосомам X (трисомия) и два сигнала - двум хромосомам X (норма)

Как уже отмечалось, одним из основных направлений развития методологических подходов к разработке новых вариантов FISH является создание ДНК проб с различными свойствами, связанными с их молекулярным составом и локализацией на хромосомах. Среди ДНК проб для метода FISH можно выделить следующие: ДНК пробы, состоящие из высокоповторяющихся последовательностей ДНК; ДНК пробы, состоящие из уникальных последовательностей ДНК генов; WCP ДНК пробы (whole chromosome probe - проба, маркирующая хромосому полностью) и 24-цветовая FISH/SKY (набор из 24-х WCP ДНК проб); ДНК пробы, состоящие из участков хромосом (MCB FISH) для MFISH. 
Наиболее частая процедура в клинической практике - FISH с использованием ДНК проб, состоящих из высокоповторяющихся последовательностей ДНК, для идентификации численных хромосомных аномалий. FISH с применением ДНК проб, состоящих из уникальных последовательностей ДНК, является методом идентификации и локализации структурных хромосомных аномалий и определения изменения ДНК на субхромосомном уровне (выявление точек разрыва). FISH с использованием WCP ДНК проб и 24-цветовая FISH/SKY (набор из 24-х WCP ДНК проб) являются дополнительными методами диагностики структурных хромосомных аномалий. Эти методы, в основном, используются для уточнения диагноза при наличии перестройки с участием нескольких хромосом. Они также могут быть использованы при диагностике транслокаций небольших участков хромосом. MCB FISH является высокоэффективным методом идентификации сложных структурных хромосомных перестроек и хромосомных микроаберраций.

CGH анализ нашел своё применение в области онкоцитогенетики и диагностики хромосомных микроаберраций у детей с умственной отсталостью. Помимо этого, серийный CGH анализ позволяет с высокой эффективностью определить потерю (делеции) или приобретение (дупликации) последовательностей хромосомной ДНК размером менее одного миллиона пн (геномные аномалии).

Необходимо знать, что при постнатальной диагностике хромосомных аномалий молекулярно-цитогенетические технологии являются дополнительными к классическим цитогенетическим методам. Инициирующей стадией диагностики хромосомных аномалий обычно является классический цитогенетический анализ, включающий в себя культивирование исследуемых клеток с целью получения метафазных пластинок с последующим применением методов дифференциального окрашивания хромосом по длине и исследованием кариотипа с помощью светового микроскопа. Данный метод позволяет идентифицировать или предположить наличие хромосомной аномалии. При необходимости, исходя из возможных цитогенетических предположений, 
применяется молекулярно-цитогенетическая диагностика. При этом выбирается участок хромосомы, последовательности ДНК которого маркирует соответствующая проба. После этого проводится молекулярно-цитогенетический анализ. Следует отметить и то, что сложные хромосомные перестройки требуют применения нескольких модификаций молекулярно-цитогенетических методов.

Особого внимания заслуживает молекулярно-цитогенетическая диагностика субтеломерных хромосомных микроаберраций. Частота данных хромосомных аномалий может достигать 5-25\% в группах детей с недифференцированными формами умственной отсталости и других нарушений психики. До создания коллекций ДНК проб, маркирующих соответствующие участки хромосом, диагностика этой патологии оставалась невозможной. Получение набора ДНК проб, маркирующих все субтеломерные участки, позволило с высокой эффективностью обнаружить данную форму хромосомной патологии. Другой возможностью идентификации хромосомных микроаберраций является применение различных вариантов метода CGH. Многие исследователи отмечают и то, что метод серийной СGH (молекулярного кариотипирования) является в значительной степени эффективным для диагностики субтеломерных хромосомных микроаберраций. Альтернативным методом диагностики субтеломерных хромосомных микроаберраций, предложенным отечественными исследователями, является FISH с ДНК пробами, маркирующими субтеломерные участки хромосом. В настоящее время известны многие клинические характеристики пациентов с субтеломерными микроаберрациями различных хромосом. Благодаря этому, становится возможным теоретически выделить ту хромосому, в которой с наибольшей вероятностью расположена микроаберрация, в результате исчезает необходимость одновременного использования нескольких проб и анализ производится с использованием лишь одной субтеломерной ДНК пробы.

Заключение. Таким образом, генетические нарушения, выявляемые у индивидуумов, достаточно гетерогенны, поэтому для 
их определения требуется применение различных методов. Причинами этих нарушений нередко могут быть различные хромосомные (геномные) микроперестройки, которые невозможно выявить с применением стандартных цитогенетических методов из-за не слишком высокого уровня разрешения этой классической технологии. С разработкой современных технологий многие учёные считают, как говорилось выше, что субтеломерные и интерстициальные перестройки могут являться причиной более 5-10\% случаев недифференцированной умственной отсталости при условии их выявления с использованием высокоразрешающего сканирования генома методом arrayCGH (с разрешением не менее 100 тысяч пн). Они также предполагают, что применение высокоразрешающих методов сканирования генома увеличивает удельный вес субтеломерных и интерстициальных перестроек при умственной отсталости и аутизме в 1,5-2 раза. Показано, что исследования больных с недифференцированными формами умственной отсталости, проведенные с помощью современных молекулярно-цитогенетических методов, способствуют более корректному определению структурных особенностей генома и при определении генетических причин позволяют классифицировать недифференцированные формы. Кроме того, подобные исследования имеют практическую значимость, а именно, благодаря им определены показания для проведения молекулярного кариотипирования (arrayCGH), определяется тактика проведения молекулярно-цитогенетических исследований (см рекомендуемую литературу), что в дальнейшем способствует эффективному медико-генетическому консультированию (см главу 8), а в отдельных случаях и пренатальной диагностике.

Суммируя результаты исследований наших лабораторий, можно сказать, что мы обследовали более 2500 пациентов с недифференцированными формами умственной отсталости различными методами (цитогенетическими и молекулярно-цитогенетическими). Учитывая данные, полученные с помощью цитогенетических исследований и подтвержденные с использованием FISH и MCB, различные хромосомные аномалии были выявлены в 10,6\% случаев. Принимая 
во внимание наличие у некоторых детей хромосомной нестабильности в виде анеуплоидии аутосом и гоносом, хромосомных перестроек (транслокаций, делеций, сайтов ломкости и т.д.), можно сказать и о том, что мозаичные хромосомные аномалии, включая низкопроцентный мозаицизм и хромосомную нестабильность, имеют относительно повышенную частоту среди детей с умственной отсталостью, ВПР и/или МАР, и этим пациентам требуется проведение исследования с использованием нескольких методов, а именно цитогенетических и молекулярно-цитогенетических технологий (FISH, $\mathrm{MCB}, \mathrm{HR} \mathrm{CGH}$ и arrayCGH). Обсуждая данные, полученные в наших лабораториях ранее при использовании HR CGH, сделано заключение о том, что этот метод является эффективным для выявления хромосомных микроаномалий (эффективность более 40 \%), и может быть использован для анализа геномных перестроек, связанных с умственной отсталостью. Однако в связи с такими ограничениями этого метода, как невозможность подтверждения (исключения) низкопроцентного мозаицизма, сбалансированных транслокаций, а также в случаях микроделеционных синдромов, когда размер перестройки является ниже разрешения HR CGH метода, применяется метод arrayCGH. При использовании этого метода микроаномалии хромосом (генома) обнаружены в 48 \% случаев, а в $37 \%$ случаев были выявлены вариации числа копий последовательностей ДНК (CNV). Методом arrayCGH также были подтверждены и/или уточнены точки разрыва, предположенные с помощью цитогенетических и других молекулярно-цитогенетических методов. Микроаномалии и/или вариации числа копий последовательностей ДНК затрагивали все хромосомы и довольно большое число генов, которые могут быть ассоциированы с недифференцированными формами умственной отсталости и аутизма. Нами был сделан вывод о том, что патогенез умственной отсталости связан со многими генами и, практически, со всеми хромосомами, и заболевание следует рассматривать в плане геномных сетей и генных взаимодействий, т. е. как связанное со специфическим 
комплексом процессов, в которые вовлекаются от нескольких десятков до нескольких тысяч генов. Единичные аномалии у индивидуумов с наследственными недифференцированными формами (например, с умственной отсталостью) указывают, скорее всего, на одно из звеньев патогенетического каскада, а не на специфическую перестройку, характерную для заболевания. Вероятно, к изучению многих недифференцированных форм предположительно наследственных заболеваний следует подходить с точки зрения персонифицированной геномной медицины, т. е. основываясь на идентификации индивидуальных особенностей вариаций генома на молекулярном и клеточном уровнях (см рекомендуемую литературу). Таким образом, следует подходить к клиническому анализу больного персонализировано, используя все современные геномные и клеточные технологии в диагностике. Становится всё более и более очевидным, что патогенез наследственных заболеваний, связанный со многими генами, необходимо рассматривать в плане геномных сетей и геномных взаимодействий. Предлагаемый биоинформатический (in silico) подход к анализу геномых перестроек позволяет определить возможные гены-кандидаты и молекулярные «процессы-мишени», связанные с патогенезом наследственных нервных и психических заболеваний. Анализируя наиболее известные методы поиска этиологических факторов недифференцированных форм, можно сделать вывод о том, что сочетание высокоразрешающих молекулярно-цитогенетических методов и in silico анализа может считаться наиболее удачной комбинацией для поиска генетических причин недифференцированных форм наследственных заболеваний.

Кроме того, применение цитогенетических и молекулярно-цитогенетических методов, направленных на идентификацию хромосомных (геномных) микроаномалий, позволяет не только выявлять те или иные численные и структурные изменения генома, но также картировать гены-кандидаты данной формы нарушения психики. Таким образом, анализ геномных вариаций и микроаномалий хромосом (генома), 
обнаруженных современными молекулярно-цитогенетическими методами, представляет несомненный интерес для выявления причин заболеваний и фактически дифференцирования изучаемых форм, определения их генетических маркеров, а также дальнейшего поиска генетических и эпигенетических механизмов патологии головного мозга.

В заключение следует также отметить значимость современных технологий молекулярной цитогенетики в изучении уже дифференцированных форм. В частности, авторы Юров И.Ю., Ворсанова С.Г. и Юров Ю.Б. предлагают оригинальную гипотезу классификации генетических заболеваний, для которых уже известен тип наследования, в журнале Molecular Cytogenetic (Молекулярная цитогенетика) (Iourov I.Y., Vorsanova S.G., Yurov Y.B. Pathway-based classification of genetic diseases. Mol Cytogenet. 2019; 12:4). Приводим краткое изложение этой гипотезы. Известно, что в медицинской генетике заболевания классифицируются в соответствии с их природой («гипотетической природой»), основанной на характере генетических нарушений. Эту классификацию можно представить как «генно-ориентированную» и «факторно-ориентированную»: болезнь может быть моногенной, олигогенной или полигенной/мультифакторной, приводя к догме о том, что гены и их взаимодействие со средой являются единственными параметрами, необходимыми для описания заболевания с генетической природой. В этой связи следует отметить, что даже моногенные заболевания могут быть ассоциированы с целым каскадом молекулярных и клеточных изменений, проявляя вариабельность в фенотипических проявлениях и патологических механизмах. Поскольку патогенетические механизмы (геномные сети) в свете современных геномных исследований оказывают большее влияние на понимание возникновения и течения болезни, чем генетические дефекты как таковые, то существует необходимость классификации болезней, отражающей как генетические причины, так и молекулярноклеточные механизмы. В данной статье авторы предлагают 
расширение общепринятой классификации заболеваний, основанной на выявленных геномных нарушениях с последующим биоинформатическим анализом при приоритизации генов и определении процессов-кандидатов. Дополнительная классификация болезни должна также фокусироваться и на специфических для болезней «молекулярных путях». Авторы предлагают, следуя традиции при создании биомедицинских терминов, использовать древнегреческие слова и приставки, а также применить слово «грифос» для обозначения типа болезни. Древнегреческое слово «грифос» одновременно означает «сеть» и «головоломку по типу мозаики» (пазл) и, соответственно, довольно удачно символизирует термин «путь» в контексте молекулярной биологии и медицины. Объединив слова «грифос» и греческие префиксы, можно предложить следующие типы обозначения болезней:

моногрифный - изменение одной геномной сети может привести к соответствующим фенотипическим проявлениям;

дигрифный, тригрифный - изменение двух или трех геномных сетей может также приводить к фенотипическим проявлениям;

олигогрифный - изменение нескольких геномных сетей может приводить к соответствующим фенотипическим проявлениям;

полигрифный - изменение многих геномных сетей может приводить к многочисленным фенотипическим проявлениям;

гомеогрифный - изменение общих геномных сетей может также приводить к соответствующим фенотипическим проявлениям при коморбидных заболеваниях.

Чтобы показать применение предлагаемой авторами классификации заболевания, приведем конкретные примеры:

1) фенилкетонурия - болезнь, вызванная мутациями в гене $P A H$, кодирующем фенилаланингидроксилазу, катализируя реакцию гидроксилирования фенилаланина в тирозин. Эту болезнь следует обозначить как моногенно-моногрифное заболевание; 
2) синдром Ретта - заболевание, вызванное генетическими нарушениями в гене $M E C P 2$, этот ген участвует в нескольких геномных сетях, главным образом, регулирующих активность генома. По предлагаемой классификации его можно обозначить как моногенно-полигрифный синдром;

3) атаксия-телеангиэктазия - синдром хромосомной нестабильности, вызванный генетическими нарушениями в гене ATM. Этот ген участвует во множестве путей регулирования поддержания стабильности генома, клеточного цикла, запрограммированной гибели клеток и т. д. По предложенной классификации эту болезнь следует также обозначить как моногенно-полигрифное заболевание;

4) случай, описанный авторами этого пособия (Iourov et al., Mol Cytogenet. 2015; 8:82. doi: 10.1186/s13039-015-0185-9), делеции короткого плеча хромосомы 3 (3p22.1p21.31) с выявленными нарушениями двух геномных сетей. По предложенной классификации эти нарушения следует обозначить как хромосомное дигрифное заболевание;

5) синдром Вильямса - заболевание, при котором точно неизвестно, сколько генных/геномных сетей нарушено, но известно, что их число не менее 3-х, но и не больше 20-ти. Этот синдром можно отнести к хромосомным олигогрифным заболеваниям;

6) синдром Неймегена (Nijmegen breakage syndrome) и атаксию-телеангиэктазию следует рассматривать, как моногенные гомеогрифные заболевания, т. к. гены, мутации в которых с ними ассоциированы, входят в одну генную/геномную сеть, но эти болезни клинически различны.

Авторы полагают, что представленная классификация имеет право на существование в свете достижений в медицинской генетике и геномике за последние десятилетия, связанных с разработкой и применением в фундаментальных исследованиях и клинической практике современных геномных и цитогеномных технологий. 


\section{Гдава 8. МЕДИКО-ГЕНЕТИЧЕСКОЕ КОНСУ ЯЬТИРОВАНИЕ (МГК)}

Одной из ключевых задач медицинской генетики остаётся осуществление комплекса профилактических мероприятий, направленных на предотвращение развития наследственно детерминированных заболеваний. При организации и проведении профилактических мероприятий следует учитывать несколько факторов:

1) большая часть наследственно обусловленных заболеваний передаётся из поколения в поколение, то есть носит семейный характер;

2) несмотря на тяжесть течения многих наследственных заболеваний, улучшение оказания медицинской помощи больным с наследственной и врождённой патологией обуславливает повышение качества жизни пациентов, что может способствовать повышению распространения мутантных генов в популяции.

Обязательной составляющей профилактических мероприятий, направленных на предупреждение рождения и развития наследственных болезний, является медико-генетическое консультирование (МГК) - это вид специализированной медицинской помощи населению, целью которой является предупреждение рождения ребёнка с врождённой и наследственной патологией.

Появление генетической консультации как самостоятельной службы в 1947 году связывают с доктором Ш. Ридом (S. Reed), который сформулировал основные задачи медико-генетической помощи и дал определение МГК. Он первым применил термин «генетическое консультировние», определив его как социальную помощь для оказания её наследственно отягощённым семьям, и написал руководство по генетическому консультированию в 1955 году. Однако, известно, что первый кабинет по МГК за рубежом был организован в 1941 году в Мичиганском университете доктором 
Д. Нилом (J. Neel, 1915-2000 гг.). Гораздо ранее, в 1929 году, советский невропатолог и генетик С.Н. Давиденков организовал МГК в России в Москве при Институте нервно-психиатрической профилактики. В 1932 году он впервые в мире сформулировал принципы медико-генетической помощи при наследственных болезнях и заболеваниях с наследственным предрасположением. Развитие МГК приостановилось в 30-х годах прошлого века из-за появления такой науки как евгеника, с которой связаны расовая дискриминация, геноцид и введение насильственной смерти в Германии как метода «оздоровления расы». В 60-70-х годах прошлого века наблюдалось возрождение и стремительное развитие МГК в разных странах мира. В настоящее время во всём мире насчитывается более 1000 генетических консультаций, в России эта цифра приближается к 100 и они функционируют в каждом регионе страны. По данным литературы известно, что от $7 \%$ до 8,5-9\% населения нуждаются в МГК. Известно, что следующие основные функции лежат в основе МГК:

1) определение типа наследственной передачи заболевания в семье;

2) оценка прогноза для будущего потомства в семье;

3) помощь при постановке диагноза наследственного заболевания, если требуются специальные генетические методы;

4) объяснение величины риска родителям в доступной форме и помощь при принятии ими решения;

5) пропаганда генетических знаний среди населения и врачей других специальностей.

Известно, что эффективное медико-генетическое консультирование связано с эффективностью диагностики. Это один из первых этапов МГК. К сожалению, обращаемость населения в МГК в России мала, и определяется как 0,5-1\% от всех семей, тогда как по расчётам она должна составлять не менее $7 \%$. Чаще всего за МГК обращаются семьи, в которых имеются больные с врождёнными пороками развития, хромосомными болезнями, нервными и психическими заболеваниями. В настоящее время расширяющиеся диагностические 
возможности, включая молекулярные и молекулярно-цитогенетические методы, позволяют достаточно эффективно установить диагноз наследственного заболевания. Следующим этапом МГК является расчёт повторного риска. Существуют два подхода к оценке генетического риска:

1) теоретические подходы к оценке, основанные на законах формальной генетики;

2) расчёт, основанный на эмпирических показателях частоты среди родственников определённой степени родства.

Достаточно чётко разработаны теоретические основы оценки генетического риска для менделирующих наследственных заболеваний (см предыдущие главы), при этом, основная задача сводится к описанию фенотипа и идентификации генотипа заболевания с поправкой на вероятностную оценку сегрегационной частоты в зависимости от генотипов родителей будущего ребёнка (см рекомендуемую литературу). При мультифакторных наследственных заболеваниях консультирование по поводу риска основывается довольно часто на эмпирических данных, поскольку порой трудно понять специфические дискретные генотипы болезни. В такой ситуации вероятностное прогнозирование связано с использованием сложных математических методов и специальных генетических моделей. Расчёт риска при хромосомной патологии также основан на эмпирических данных. В медико-генетической практике используются таблицы эмпирического риска (см рекомендуемую литературу). При хромосомных аномалиях учитывается тип хромосомных нарушений и возраст матери.

Заключение о повторном риске заболевания предоставляется непосредственно членам семьи (иногда нескольким членам), поэтому требуется разъяснение его смысла в доступной форме. При этом основным принципом для врача-генетика является недирективная консультация, которая предполагает, что окончательное решение вопроса принадлежит семье, а не врачу-генетику. Знание врачом содержания и принципов 
МГК позволяет более эффективно осуществлять профилактику наследственных заболеваний.

Умение проводить профилактические мероприятия, направленные на предупреждение появления наследственных и врождённых заболеваний в семье, что способствует снижению частоты широко распространённых наследственных заболеваний, в том числе и мультифакторной природы, необходимо для практической деятельности, прежде всего, врача-генетика, а также педиатра, психиатра и невропатолога.

Знание молекулярных, цитогенетических и клинических основ наследственных болезней, а также знакомство с рекомендуемой литературой, помогут исследователям с высшим медицинским, биологическим и психологическим образованием постигать основы медицинской генетики и успешно работать в подразделениях генетического профиля педиатрических, психиатрических и психологических учреждений, а также в медико-генетических консультациях.

Собственные исследования и публикация были частично поддержаны Госзаданием Минздрава России «Персонифицированная геномика недифференцированных форм умственной отсталости у детей», АААА-А18-118051590122-7. 


\section{РЕКОМЕНДУЕМАЯ ЛИТЕРАТУРА}

1. Ворсанова С.Г., Юров Ю.Б., Чернышов В.Н. Хромосомные синдромы и аномалии. Классификация и номенклатура. Ростовна-Дону: Изд. РГМУ, 1999, 192 с.

2. Ворсанова С.Г., Юров Ю.Б., Чернышов В.Н. Медицинская цитогенетика (учебное пособие). М.: Изд. Медпрактика, 2006, 300 с.

3. Ворсанова С.Г., Юров И.Ю., Соловьёв И.В., Юров Ю.Б. Гетерохроматиновые районы хромосом человека: клинико-биологические аспекты. М.: Изд. Медпрактика, 2008, 300 с.

4. Ворсанова С.Г., Юров И.Ю., Куринная О.С., Юров Ю.Б. Недифференцированные формы умственной отсталости у детей: цитогенетические и молекулярно-цитогенетические аспекты: монография. М.: Издательский дом Академии Естествознания, 2017, 244 с.

5. Ворсанова С.Г., Юров Ю.Б., Сильванович А.П., Демидова И.А., Юров И.Ю. Современные представления о молекулярной генетике и геномике аутизма.//Фундаментальные Исследования. 2013. № 4. Часть 2. С. 356-367.

6. Ворсанова С.Г., Юров Ю.Б., Демидова И.А., Колотий А.Д., Куринная О.С., Кравец В.С., Юров И.Ю. Биомаркеры неонкологических болезней мозга, обусловленных хромосомной нестабильностью, у детей.//Научный Результат. Медицина и Фармация. 2018. Том 4. № 2. С. 8-17.

7. Гинтер Е.К. Медицинская генетика. М.: Изд. Медицина, 2003, 448 c.

8. Гинтер Е.К., Козлова С.И. (редакция) Современное медикогенетическое консультирование. М.: Изд. Авторская академия, 2016, 304 c.

9. Жимулёв И.Ф. Общая и молекулярная генетика. Учебное пособие. 4-е издание. Новосибирск: Изд. Сибирское университетское издательство, 2007, 479 с.

10. Иванов В.П., Чурносов М.И. Методическое пособие по медицинской генетике. Белгород: Изд. Белгородский Государственный Университет, 2004, 102 с. 
11. Козлова С.И., Демикова Н.С. Наследственные синдромы и медико-генетическое консультирование. 3-е издание, перераб. и дополн. М.: Изд. Авторская академия, 2007, 448 с.

12. Коряков Д.Е., Жимулёв И.Ф. Хромосомы. Структура и функции. Новосибирск: Изд. СО РАН, 2009, 258 с.

13. Новиков П.В. СЕМИОТИКА наследственных болезней у детей. М.: Изд. «Триада-Х», 2009, 430 с.

14. Тиганов А.С., Юров Ю.Б., Ворсанова С.Г., Юров И.Ю. Нестабильность генома головного мозга: этиология, патогенез и новые биологические маркеры психических болезней.// Вестник Российской Академии Медицинских Наук. 2012. № 9. С. 45-53.

15. Юров И.Ю., Ворсанова С.Г., Юров Ю.Б. Современные достижения в молекулярно-цитогенетической диагностике наследственных болезней (лекция).//Клиническая Лабораторная Диагностика. 2005. № 11. С. 21-29.

16. Юров И.Ю., Ворсанова С.Г., Юров Ю.Б. Геномные и хромосомные болезни центральной нервной системы: молекулярные и цитогенетические аспекты. М.: Изд. «Медпрактика $-\mathrm{M»,} \mathrm{2014,} 384$ c.

17. Юров И.Ю., Ворсанова С.Г., Зеленова М.А., Юров Ю.Б. Анеуплоидия хромосомы 21 при заболеваниях головного мозга.// Фундаментальные Исследования. 2015. № 7 (Часть 1). С. 61-70.

18. Юров Ю.Б., Ворсанова С.Г., Юров И.Ю. Молекулярная цитогенетика и геномика аутизма.// Молекулярная Медицина. 2014. № 2. C. 3-7.

19. ISCN 2013 - An international systeme for human cytogenetic nomenclature. Shaffer L.S., McGowan-Jordan J., Schmid M. (ed) // S. Karger, Basel, 2013, 140 c.

20. ISCN 2016 - An international systeme for human cytogenetic nomenclature. McGowan-Jordan J., Simons A., Schmid M. (ed) // S. Karger, Basel, 2016, 139 c.

21. Vorsanova S.G., Yurov Y.B., Iourov I.Y. Human interphase chromosomes: a review of available molecular cytogenetic technologies.// Molecular Cytogenetics. 2010. 3(1):1. 


\section{РЕКОМЕНДУЕМЫЕ ЭЯЕКТРОННЫЕ РЕСУРСЫ}

DECIPHER - DECIPHER - Mapping the Clinical Genome база данных по картированию геномных аномалий и их фенотипы, институт Ф. Сэнджера: https://decipher.sanger.ac.uk.

DGV - Database of Genomic Variants - catalogue of structural variation in the human genome - каталог структурных вариантов генома человека: http://dgv.tcag.ca/dgv/app/home.

ECARUCA - European Cytogeneticists Association Register of Unbalanced Chromosome Aberrations - Регистр несбалансированных хромосомных аберрации Европейской ассоциации цитогенетиков: http://ecaruca.radboudumc.nl:8080/ecaruca.

Face2Gene - клинический ресурс для анализа изображений: https://www.face2gene.com.

OMIM - Online Mendelian Inheritance in Man (электронный каталог наследственных заболеваний): http://www.ncbi.nlm.nih. gov/sites/entrez? $\mathrm{db}=$ OMIM.

POSSUM - Pictures of Standard Syndromes and Undiagnosed Malformations (электронная база данных наследственных синдромов): http:www.possumcore.com/nuxeo/login.jsp.

PubMed - наиболее обширная база данных научных статей, посвященных различным аспектам биологии и медицины: http:// www.ncbi.nlm.nih.gov/sites/entrez. 


\section{ПРИЯОЖЕНИЕ}

\section{Оценка основных антропометрических данных у детей}

В зависимости от интервала, которому соответствует антропометрический показатель, дается его оценка, а также оценка физического развития ребенка в целом.

Интервал до 3 центиля - область «очень низких величин».

Интервал от 3 до 10 центиля - область «низких величин».

Интервал от 10 до 25 центиля - область величин «ниже среднего».

Интервал от 25 до 75 центиля - область «средних величин».

Интервал от 75 до 90 центиля - область величин «выше среднего».

Интервал от 90 до 97 центиля - область «высоких величин».

Интервал выше 97 центиля - область «очень высоких величин».

Если рост ребенка соответствует интервалу 25-75 центилей, то физическое развитие считается средним, если 10-25 центилей - ниже среднего, 3-10 центилей - низкое (карликовость), ниже 3 центиля - очень низкое. Таким же образом дается оценка высокого физического развития (интервал 90-97 центилей), выше среднего (75-90 центилей) и очень высокого (выше 97 центиля).

Оценка окружности головы дается следующим образом: значения, соответствующие интервалу более 90 центилей, расцениваются как макроцефалия, и менее 10 центилей - как микроцефалия.

Оценка гармоничности развития проводится следующим образом. Если различия между длиной, массой тела и окружностью груди не превышают одного интервала, то говорят о гармоничном физическом развитии. В случае, когда различия этих антропометрических показателей составляют 2 интервала и более, развитие считается дисгармоничным. Например, у больного синдромом Марфана длина тела оценена как очень высокая величина, масса тела - средняя, а окружность груди ниже среднего. В этом случае физическое развитие ребенка высоко дисгармоничное. 
И.Ю. Юров, С.Г. Ворсанова, В.Ю. Воинова, М.И. Чурносов, Ю.Б. Юров

Центильные величины длины тела (см) мальчиков (0 мес. - 17 лет)

\begin{tabular}{|c|c|c|c|c|c|c|}
\hline \multirow{2}{*}{ Возраст } & \multicolumn{6}{|c|}{ Центили } \\
\hline & 3 & 10 & 25 & 75 & 90 & 97 \\
\hline 0 мес. & 48,0 & 48,9 & 50,0 & 53,2 & 54,3 & 55,1 \\
\hline 1 & 50,5 & 51,5 & 52,8 & 56,3 & 57,5 & 58,7 \\
\hline 2 & 53,4 & 54,3 & 55,8 & 59,5 & 61,0 & 62,1 \\
\hline 3 & 56,1 & 57,0 & 58,6 & 62,1 & 64,0 & 65,5 \\
\hline 4 & 58,6 & 59,5 & 61,3 & 65,6 & 67,0 & 68,7 \\
\hline 5 & 61,0 & 61,9 & 63,4 & 67,9 & 69,6 & 70,9 \\
\hline 6 & 63,0 & 64,0 & 65,6 & 69,9 & 71,3 & 72,5 \\
\hline 7 & 65,0 & 65,9 & 67,5 & 71,4 & 73,0 & 74,1 \\
\hline 8 & 66,5 & 67,6 & 68,9 & 73,0 & 74,5 & 75,7 \\
\hline 9 & 67,8 & 68,8 & 70,1 & 74,5 & 75,9 & 77,1 \\
\hline 10 & 68,8 & 69,9 & 71,3 & 76,1 & 77,4 & 78,8 \\
\hline 11 & 69,9 & 71,0 & 72,6 & 77,3 & 78,9 & 80,4 \\
\hline 12 & 71,0 & 72,0 & 73,8 & 78,5 & 80,3 & 81,7 \\
\hline 15 & 72,9 & 74,3 & 76,0 & 81,3 & 86,5 & 84,9 \\
\hline 18 & 75,0 & 76,5 & 78,4 & 84,4 & 83,4 & 88,2 \\
\hline 21 & 77,2 & 78,6 & 80,8 & 86,8 & 88,2 & 91,0 \\
\hline 24 & 79,4 & 81,0 & 83,0 & 88,4 & 92,0 & 93,8 \\
\hline 27 & 81,4 & 83,2 & 85,5 & 92,2 & 94,6 & 96,3 \\
\hline
\end{tabular}


Цитогенетические, молекулярные и клинические основы генетически обусловленных болезней

\begin{tabular}{|c|c|c|c|c|c|c|}
\hline 30 & 83,7 & 85,2 & 87,5 & 94,8 & 97,2 & 99,0 \\
\hline 33 & 86,0 & 87,4 & 90,0 & 97,4 & 99,7 & 101,4 \\
\hline 36 & 88,0 & 89,6 & 92,1 & 99,7 & 102,2 & 103,9 \\
\hline 3,5 лет & 90,3 & 92,1 & 95,0 & 102,5 & 105,0 & 106,8 \\
\hline 4,0 & 93,2 & 95,4 & 98,3 & 105,5 & 108,0 & 110,0 \\
\hline 4,5 & 96,3 & 98,3 & 101,2 & 108,5 & 111,2 & 113,5 \\
\hline 5,0 & 98,4 & 101,7 & 104,9 & 112,0 & 114,5 & 117,2 \\
\hline 5,5 & 102,4 & 104,7 & 108,0 & 115,2 & 118,0 & 120,1 \\
\hline 6,0 & 105,5 & 108,0 & 110,8 & 118,8 & 121,4 & 123,3 \\
\hline 6,5 & 108,6 & 110,9 & 113,9 & 122,0 & 124,4 & 126,4 \\
\hline 7,0 & 110,3 & 113,8 & 117,0 & 125,0 & 127,9 & 130,0 \\
\hline 8,0 & 116,4 & 118,8 & 122,0 & 131,0 & 134,3 & 136,4 \\
\hline 9,0 & 121,5 & 124,6 & 127,5 & 136,5 & 140,3 & 142,5 \\
\hline 10,0 & 126,4 & 129,2 & 133,0 & 142,0 & 146,2 & 149,1 \\
\hline 11,0 & 131,2 & 134,0 & 138,0 & 148,3 & 152,9 & 155,2 \\
\hline 12,0 & 135,8 & 138,8 & 142,7 & 154,9 & 159,5 & 162,4 \\
\hline 13,0 & 140,2 & 143,6 & 147,4 & 160,4 & 165,8 & 169,6 \\
\hline 14,0 & 144,9 & 148,3 & 152,4 & 166,4 & 172,2 & 176,0 \\
\hline 15,0 & 149,3 & 153,2 & 158,0 & 172,0 & 178,0 & 181,0 \\
\hline 16,0 & 154,0 & 158,0 & 162,2 & 177,4 & 182,0 & 185,0 \\
\hline 17,0 & 159,0 & & 168,0 & & & \\
\hline
\end{tabular}


И.Ю. Юров, С.Г. Ворсанова, В.Ю. Воинова, М.И. Чурносов, Ю.Б. Юров

Центильные величины массы тела (кг) мальчиков (0 мес. - 17 лет)

\begin{tabular}{|c|c|c|c|c|c|c|}
\hline \multirow{2}{*}{ Возраст } & \multicolumn{6}{|c|}{ Центили } \\
\hline & 3 & 10 & 25 & 75 & 90 & 97 \\
\hline 0 мес. & 2,4 & 2,7 & 3,0 & 3,7 & 4,0 & 4,4 \\
\hline 1 & 3,1 & 3,5 & 3,8 & 4,5 & 5,2 & 5,6 \\
\hline 2 & 3,9 & 4,3 & 4,6 & 5,5 & 6,2 & 6,6 \\
\hline 3 & 4,5 & 4,9 & 5,4 & 6,4 & 7,0 & 7,5 \\
\hline 4 & 5,2 & 5,6 & 6,2 & 7,2 & 7,9 & 8,4 \\
\hline 5 & 5,8 & 6,2 & 6,8 & 7,9 & 8,6 & 9,1 \\
\hline 6 & 6,4 & 6,8 & 7,4 & 8,6 & 9,2 & 9,7 \\
\hline 7 & 6,9 & 7,4 & 7,9 & 9,1 & 9,8 & 10,3 \\
\hline 8 & 7,4 & 7,8 & 8,4 & 9,6 & 10,3 & 10,8 \\
\hline 9 & 7,8 & 8,3 & 8,9 & 10,1 & 10,9 & 11,3 \\
\hline 10 & 8,0 & 8,6 & 9,2 & 10,6 & 11,3 & 11,8 \\
\hline 11 & 8,3 & 8,9 & 9,5 & 11,0 & 11,8 & 12,3 \\
\hline 12 & 8,6 & 9,1 & 9,8 & 11,5 & 12,2 & 12,7 \\
\hline 15 & 9,2 & 9,6 & 10,5 & 12,2 & 12,9 & 13,5 \\
\hline 18 & 9,6 & 10,2 & 11,0 & 12,8 & 13,6 & 14,2 \\
\hline 21 & 10,1 & 10,6 & 11,5 & 13,5 & 14,3 & 14,9 \\
\hline 24 & 10,6 & 11,1 & 12,0 & 14,1 & 14,9 & 15,4 \\
\hline 27 & 11,1 & 11,6 & 12,4 & 14,6 & 15,4 & 15,9 \\
\hline
\end{tabular}


Цитогенетические, молекулярные и клинические основы генетически обусловленных болезней

\begin{tabular}{|c|c|c|c|c|c|c|}
\hline 30 & 11,5 & 12,0 & 12,8 & 15,1 & 16,0 & 16,5 \\
\hline 33 & 11,9 & 12,4 & 13,2 & 15,6 & 16,5 & 17,0 \\
\hline 36 & 12,1 & 12,8 & 13,6 & 16,0 & 16,9 & 17,5 \\
\hline 3,5 лет & 12,7 & 13,4 & 14,2 & 17,0 & 18,0 & 18,7 \\
\hline 4,0 & 13,3 & 14,2 & 15,1 & 18,0 & 19,1 & 20,0 \\
\hline 4,5 & 14,0 & 14,9 & 15,9 & 19,0 & 20,6 & 21,7 \\
\hline 5,0 & 14,8 & 15,7 & 16,8 & 20,1 & 22,0 & 23,2 \\
\hline 5,5 & 15,5 & 16,6 & 17,8 & 21,4 & 23,4 & 25,1 \\
\hline 6,0 & 16,3 & 17,6 & 18,9 & 22,6 & 24,9 & 27,0 \\
\hline 6,5 & 17,2 & 18,4 & 20,0 & 24,0 & 26,4 & 29,0 \\
\hline 7,0 & 18,2 & 19,6 & 21,3 & 25,5 & 28,0 & 31,1 \\
\hline 8,0 & 20,0 & 21,5 & 23,4 & 28,4 & 31,7 & 35,1 \\
\hline 9,0 & 22,0 & 23,4 & 25,6 & 31,4 & 35,4 & 39,2 \\
\hline 10,0 & 24,0 & 25,6 & 28,0 & 35,1 & 39,5 & 45,0 \\
\hline 11,0 & 26,0 & 28,0 & 31,0 & 39,2 & 44,5 & 50,5 \\
\hline 12,0 & 28,3 & 30,4 & 34,4 & 43,8 & 50,0 & 57,0 \\
\hline 13,0 & 31,0 & 33,4 & 39,8 & 49,0 & 56,2 & 63,6 \\
\hline 14,0 & 34,0 & 35,2 & 42,2 & 54,6 & 62,2 & 70,6 \\
\hline 15,0 & 37,8 & 40,8 & 46,9 & 60,2 & 65,1 & 76,5 \\
\hline 16,0 & 41,2 & 45,4 & 51,8 & 65,9 & 73,0 & 82,5 \\
\hline 17,0 & 46,4 & 50,5 & 56,8 & 70,6 & 78,0 & 86,2 \\
\hline
\end{tabular}


И.Ю. Юров, С.Г. Ворсанова, В.Ю. Воинова, М.И. Чурносов, Ю.Б. Юров

\section{Центильные величины окружности головы (см) мальчиков (0 мес. - 17 лет)}

\begin{tabular}{|c|c|c|c|c|c|c|}
\hline \multirow{2}{*}{ Возраст } & \multicolumn{6}{|c|}{ Центили } \\
\hline & 3 & 10 & 25 & 75 & 90 & 97 \\
\hline 0 мес. & 32,5 & 33,2 & 43,0 & 35,5 & 36,5 & 37,7 \\
\hline 1 & 34,8 & 35,3 & 36,0 & 37,9 & 39,0 & 39,8 \\
\hline 2 & 36,9 & 37,3 & 38,0 & 40,3 & 40,9 & 41,8 \\
\hline 3 & 38,4 & 38,8 & 39,5 & 41,6 & 42,5 & 43,3 \\
\hline 4 & 39,6 & 40,2 & 40,8 & 42,9 & 43,8 & 44,5 \\
\hline 5 & 40,6 & 41,2 & 42,0 & 44,0 & 45,0 & 45,9 \\
\hline 6 & 41,5 & 42,0 & 42,7 & 45,3 & 46,0 & 46,7 \\
\hline 7 & 42,2 & 42,8 & 43,7 & 46,1 & 47,0 & 47,7 \\
\hline 8 & 42,8 & 43,6 & 44,2 & 46,8 & 47,7 & 48,4 \\
\hline 9 & 43,5 & 44,0 & 44,8 & 47,4 & 48,3 & 49,0 \\
\hline 10 & 44,0 & 44,6 & 45,4 & 48,0 & 48,8 & 49,6 \\
\hline 11 & 44,3 & 45,0 & 45,9 & 48,6 & 49,3 & 50,0 \\
\hline 12 & 44,6 & 45,3 & 46,2 & 49,1 & 49,8 & 50,7 \\
\hline 15 & 45,3 & 46,0 & 46,7 & 49,5 & 50,3 & 51,3 \\
\hline 18 & 46,0 & 46,6 & 47,3 & 49,9 & 50,7 & 51,6 \\
\hline 21 & 46,5 & 47,2 & 47,7 & 50,3 & 51,0 & 52,0 \\
\hline 24 & 47,0 & 47,6 & 48,1 & 50,5 & 51,3 & 52,3 \\
\hline 27 & 47,3 & 47,9 & 48,5 & 50,8 & 51,7 & 52,7 \\
\hline
\end{tabular}


Цитогенетические, молекулярные и клинические основы генетически обусловленных болезней

\begin{tabular}{|c|c|c|c|c|c|c|}
\hline 30 & 47,5 & 48,2 & 48,8 & 51,1 & 52,0 & 53,0 \\
\hline 33 & 47,8 & 48,4 & 49,2 & 51,3 & 52,3 & 53,3 \\
\hline 36 & 48,0 & 48,6 & 49,5 & 51,5 & 52,6 & 53,5 \\
\hline 3,5 лет & 48,6 & 49,2 & 49,9 & 52,0 & 53,0 & 54,0 \\
\hline 4,0 & 49,0 & 49,6 & 50,2 & 52,4 & 53,4 & 54,3 \\
\hline 4,5 & 49,3 & 49,8 & 50,4 & 52,7 & 53,8 & 54,6 \\
\hline 5,0 & 49,6 & 50,1 & 50,7 & 53,1 & 54,2 & 55,0 \\
\hline 5,5 & 49,8 & 50,4 & 51,0 & 53,5 & 54,5 & 55,5 \\
\hline 6,0 & 50,0 & 50,6 & 51,2 & 54,0 & 54,8 & 55,7 \\
\hline 6,5 & 50,2 & 50,8 & 51,4 & 54,3 & 55,0 & 55,8 \\
\hline 7,0 & 50,4 & 51,0 & 51,6 & 54,5 & 55,3 & 56,0 \\
\hline 8,0 & 50,5 & 51,4 & 52,0 & 55,0 & 55,8 & 56,6 \\
\hline 9,0 & 50,8 & 51,7 & 52,5 & 55,5 & 56,3 & 57,2 \\
\hline 10,0 & 51,2 & 52,0 & 52,8 & 56,0 & 56,7 & 57,7 \\
\hline 11,0 & 51,5 & 52,3 & 53,2 & 56,3 & 57,2 & 58,2 \\
\hline 12,0 & 51,7 & 52,6 & 53,5 & 56,7 & 57,7 & 58,8 \\
\hline 13,0 & 51,9 & 52,8 & 53,7 & 57,3 & 58,1 & 59,2 \\
\hline 14,0 & 52,1 & 53,0 & 54,0 & 57,5 & 58,5 & 59,6 \\
\hline 15,0 & 52,3 & 53,2 & 54,3 & 57,8 & 58,8 & 60,0 \\
\hline 16,0 & 52,4 & 53,4 & 54,4 & 57,9 & 59,0 & 60,1 \\
\hline 17,0 & 52,5 & 53,5 & 54,6 & 58,0 & 59,1 & 60,2 \\
\hline
\end{tabular}


И.Ю. Юров, С.Г. Ворсанова, В.Ю. Воинова, М.И. Чурносов, Ю.Б. Юров

Центильные величины окружности груди (см) у мальчиков (0 мес. - 17 лет)

\begin{tabular}{|c|c|c|c|c|c|c|}
\hline \multirow{2}{*}{ Возраст } & \multicolumn{6}{|c|}{ Центили } \\
\hline & 3 & 10 & 25 & 75 & 90 & 97 \\
\hline 0 мес. & 31,7 & 32,3 & 33,5 & 36,0 & 36,8 & 37,3 \\
\hline 1 & 33,3 & 34,1 & 35,4 & 38,0 & 38,9 & 39,4 \\
\hline 2 & 35,0 & 35,7 & 37,0 & 40,0 & 40,8 & 41,6 \\
\hline 3 & 36,5 & 37,3 & 38,4 & 42,1 & 43,1 & 43,8 \\
\hline 4 & 38,1 & 38,8 & 39,8 & 43,5 & 44,5 & 45,7 \\
\hline 5 & 39,3 & 40,1 & 41,1 & 45,0 & 46,2 & 47,7 \\
\hline 6 & 40,6 & 41,4 & 42,4 & 46,3 & 47,6 & 49,0 \\
\hline 7 & 41,7 & 42,5 & 43,4 & 47,5 & 48,9 & 50,1 \\
\hline 8 & 42,7 & 43,5 & 44,4 & 48,5 & 49,9 & 51,1 \\
\hline 9 & 43,6 & 44,3 & 45,2 & 49,3 & 50,7 & 52,0 \\
\hline 10 & 44,3 & 45,0 & 46,0 & 50,0 & 51,5 & 52,8 \\
\hline 11 & 44,8 & 45,6 & 46,6 & 50,8 & 52,2 & 53,6 \\
\hline 12 & 45,3 & 46,1 & 47,0 & 51,2 & 52,8 & 54,3 \\
\hline 15 & 46,0 & 46,8 & 47,9 & 51,9 & 53,7 & 55,0 \\
\hline 18 & 46,5 & 47,4 & 48,6 & 52,4 & 54,3 & 55,6 \\
\hline 21 & 47,0 & 47,9 & 49,1 & 52,9 & 54,7 & 56,0 \\
\hline 24 & 47,6 & 48,4 & 49,5 & 53,2 & 55,1 & 56,4 \\
\hline 27 & 47,8 & 48,7 & 49,9 & 53,5 & 55,6 & 56,8 \\
\hline
\end{tabular}


Цитогенетические, молекулярные и клинические основы генетически обусловленных болезней

\begin{tabular}{|c|c|c|c|c|c|c|}
\hline 30 & 48,2 & 49,1 & 50,3 & 53,9 & 55,8 & 57,3 \\
\hline 33 & 48,4 & 49,3 & 50,5 & 54,2 & 56,1 & 57,7 \\
\hline 36 & 48,6 & 49,7 & 50,8 & 54,6 & 56,4 & 58,2 \\
\hline 3,5 лет & 49,2 & 50,3 & 51,5 & 55,0 & 57,1 & 59,0 \\
\hline 4,0 & 50,0 & 51,2 & 52,4 & 55,8 & 58,0 & 59,9 \\
\hline 4,5 & 50,8 & 52,0 & 53,3 & 56,9 & 59,0 & 61,2 \\
\hline 5,0 & 51,3 & 52,8 & 54,0 & 58,0 & 60,0 & 62,6 \\
\hline 5,5 & 52,2 & 53,5 & 55,0 & 59,1 & 61,3 & 63,8 \\
\hline 6,0 & 53,0 & 54,4 & 56,0 & 60,2 & 62,5 & 65,1 \\
\hline 6,5 & 53,8 & 55,2 & 57,0 & 61,3 & 63,8 & 66,4 \\
\hline 7,0 & 54,6 & 56,2 & 57,9 & 62,3 & 65,1 & 67,9 \\
\hline 8,0 & 56,1 & 58,0 & 60,0 & 64,8 & 67,9 & 70,8 \\
\hline 9,0 & 57,7 & 59,6 & 61,9 & 67,1 & 70,6 & 73,8 \\
\hline 10,0 & 59,3 & 61,4 & 63,9 & 69,8 & 73,6 & 76,8 \\
\hline 11,0 & 61,1 & 63,0 & 66,0 & 72,1 & 76,2 & 79,8 \\
\hline 12,0 & 62,6 & 65,0 & 68,0 & 74,9 & 79,0 & 82,8 \\
\hline 13,0 & 64,7 & 66,9 & 70,2 & 78,2 & 82,2 & 87,0 \\
\hline 14,0 & 67,0 & 68,6 & 73,1 & 81,8 & 86,2 & 91,0 \\
\hline 15,0 & 70,0 & 72,6 & 76,3 & 85,7 & 90,1 & 94,2 \\
\hline 16,0 & 73,3 & 76,1 & 80,0 & 89,9 & 93,6 & 97,0 \\
\hline 17,0 & 77,0 & 80,1 & 82,9 & 92,2 & 95,5 & 98,4 \\
\hline
\end{tabular}


И.Ю. Юров, С.Г. Ворсанова, В.Ю. Воинова, М.И. Чурносов, Ю.Б. Юров

Центильные величины длины тела (см) девочек (0 мес. - 17 лет)

\begin{tabular}{|c|c|c|c|c|c|c|}
\hline \multirow{2}{*}{ Возраст } & \multicolumn{6}{|c|}{ Центили } \\
\hline & 3 & 10 & 25 & 75 & 90 & 97 \\
\hline 0 мес. & 47,0 & 46,0 & 49,2 & 52,1 & 53,3 & 54,5 \\
\hline 1 & 49,7 & 50,0 & 52,4 & 55,3 & 56,9 & 57,7 \\
\hline 2 & 52,2 & 53,3 & 55,0 & 58,6 & 59,9 & 60,8 \\
\hline 3 & 55,1 & 56,1 & 57,9 & 61,5 & 63,0 & 63,9 \\
\hline 4 & 57,4 & 58,6 & 60,5 & 64,1 & 65,6 & 66,4 \\
\hline 5 & 59,9 & 61,0 & 62,8 & 66,4 & 67,8 & 68,8 \\
\hline 6 & 62,1 & 63,0 & 64,3 & 68,2 & 69,8 & 70,8 \\
\hline 7 & 63,7 & 64,2 & 66,4 & 70,0 & 71,6 & 72,7 \\
\hline 8 & 65,2 & 66,1 & 67,7 & 71,6 & 73,1 & 75,2 \\
\hline 9 & 66,5 & 67,5 & 69,3 & 72,8 & 74,5 & 75,8 \\
\hline 10 & 67,7 & 68,8 & 70,5 & 74,2 & 75,9 & 77,1 \\
\hline 11 & 69,0 & 70,3 & 71,7 & 75,7 & 77,1 & 78,3 \\
\hline 12 & 71,4 & 71,4 & 72,8 & 76,3 & 78,3 & 79,3 \\
\hline 15 & 72,2 & 73,6 & 75,2 & 78,8 & 81,2 & 82,4 \\
\hline 18 & 74,0 & 75,8 & 77,5 & 82,1 & 84,4 & 86,0 \\
\hline 21 & 76,0 & 78,2 & 80,0 & 84,6 & 87,4 & 88,8 \\
\hline 24 & 78,4 & 80,4 & 82,6 & 87,5 & 90,2 & 92,2 \\
\hline 27 & 80,8 & 83,0 & 85,4 & 90,1 & 93,0 & 94,7 \\
\hline
\end{tabular}


Цитогенетические, молекулярные и клинические основы генетически обусловленных болезней

\begin{tabular}{|c|c|c|c|c|c|c|}
\hline 30 & 83,4 & 85,6 & 87,8 & 92,8 & 95,6 & 97,3 \\
\hline 33 & 85,9 & 88,2 & 90,3 & 95,5 & 98,2 & 100,0 \\
\hline 36 & 88,6 & 90,8 & 92,9 & 98,1 & 100,8 & 102,9 \\
\hline 3,5 лет & 91,0 & 93,4 & 95,6 & 101,0 & 103,9 & 105,8 \\
\hline 4,0 & 94,0 & 96,2 & 98,4 & 104,2 & 106,9 & 109,1 \\
\hline 4,5 & 96,9 & 99,3 & 101,5 & 107,1 & 110,6 & 114,0 \\
\hline 5,0 & 99,9 & 102,4 & 104,9 & 110,7 & 114,0 & 116,5 \\
\hline 5,5 & 102,5 & 105,2 & 108,0 & 114,5 & 117,1 & 120,0 \\
\hline 6,0 & 105,3 & 108,0 & 111,0 & 118,0 & 120,8 & 124,0 \\
\hline 6,5 & 108,0 & 110,5 & 114,0 & 121,7 & 124,2 & 127,4 \\
\hline 7,0 & 111,0 & 113,6 & 117,1 & 125,0 & 128,1 & 131,3 \\
\hline 8,0 & 116,6 & 119,4 & 123,0 & 131,0 & 134,4 & 137,6 \\
\hline 9,0 & 122,0 & 124,4 & 128,5 & 136,7 & 140,6 & 143,8 \\
\hline 10,0 & 127,0 & 130,0 & 133,8 & 142,5 & 146,6 & 150,1 \\
\hline 11,0 & 131,0 & 134,2 & 138,6 & 148,6 & 153,9 & 156,8 \\
\hline 12,0 & 135,2 & 138,4 & 143,0 & 155,1 & 159,3 & 163,5 \\
\hline 13,0 & 139,5 & 143,1 & 148,0 & 160,3 & 164,3 & 168,0 \\
\hline 14,0 & 144,0 & 147,4 & 152,4 & 164,2 & 168,0 & 170,5 \\
\hline 15,0 & 148,1 & 151,6 & 156,3 & 167,0 & 170,3 & 172,6 \\
\hline 16,0 & 151,7 & 155,0 & 158,3 & 169,0 & 172,0 & 174,1 \\
\hline 17,0 & 154,2 & 157,3 & 161,2 & 170,0 & 173,2 & 175,5 \\
\hline
\end{tabular}


И.Ю. Юров, С.Г. Ворсанова, В.Ю. Воинова, М.И. Чурносов, Ю.Б. Юров

Центильные величины массы тела (кг) девочек (0 мес. - 17 лет)

\begin{tabular}{|c|c|c|c|c|c|c|}
\hline \multirow{2}{*}{ Возраст } & \multicolumn{6}{|c|}{ Центили } \\
\hline & 3 & 10 & 25 & 75 & 90 & 97 \\
\hline 0 мес. & 2,3 & 2,5 & 3,0 & 3,5 & 3,8 & 4,0 \\
\hline 1 & 3,0 & 3,3 & 3,7 & 4,3 & 4,6 & 4,9 \\
\hline 2 & 3,7 & 4,0 & 4,4 & 5,0 & 5,3 & 5,6 \\
\hline 3 & 4,4 & 4,6 & 5,0 & 5,7 & 6,1 & 6,5 \\
\hline 4 & 5,0 & 5,3 & 5,6 & 6,5 & 6,9 & 7,4 \\
\hline 5 & 5,5 & 5,8 & 6,2 & 7,2 & 7,7 & 8,2 \\
\hline 6 & 6,1 & 6,3 & 6,8 & 7,9 & 8,5 & 9,0 \\
\hline 7 & 6,5 & 6,8 & 7,3 & 8,5 & 9,1 & 9,7 \\
\hline 8 & 7,0 & 7,3 & 7,7 & 9,1 & 9,7 & 10,5 \\
\hline 9 & 7,4 & 7,7 & 8,2 & 9,6 & 10,4 & 11,2 \\
\hline 10 & 7,7 & 8,1 & 8,7 & 10,1 & 11,2 & 11,3 \\
\hline 11 & 8,1 & 8,5 & 9,1 & 10,6 & 11,5 & 12,2 \\
\hline 12 & 8,3 & 8,8 & 9,4 & 11,0 & 11,9 & 12,6 \\
\hline 15 & 8,9 & 9,4 & 10,0 & 11,7 & 12,7 & 13,3 \\
\hline 18 & 9,4 & 9,9 & 10,6 & 12,5 & 13,4 & 13,9 \\
\hline 21 & 9,8 & 10,4 & 11,1 & 13,1 & 13,9 & 14,6 \\
\hline 24 & 10,3 & 10,9 & 11,6 & 13,5 & 14,5 & 15,2 \\
\hline 27 & 10,8 & 11,3 & 12,0 & 14,0 & 15,0 & 15,7 \\
\hline
\end{tabular}


Цитогенетические, молекулярные и клинические основы генетически обусловленных болезней

\begin{tabular}{|c|c|c|c|c|c|c|}
\hline 30 & 11,2 & 11,7 & 12,5 & 14,5 & 15,5 & 16,3 \\
\hline 33 & 11,5 & 12,1 & 12,9 & 14,9 & 16,0 & 16,8 \\
\hline 36 & 11,8 & 12,5 & 13,3 & 15,4 & 16,5 & 17,3 \\
\hline 3,5 лет & 12,4 & 13,1 & 14,0 & 16,3 & 17,8 & 18,6 \\
\hline 4,0 & 13,1 & 13,9 & 14,8 & 17,2 & 19,0 & 20,0 \\
\hline 4,5 & 13,8 & 14,9 & 15,8 & 18,4 & 20,4 & 21,6 \\
\hline 5,0 & 14,9 & 15,8 & 16,9 & 19,8 & 21,9 & 23,7 \\
\hline 5,5 & 15,6 & 16,6 & 17,8 & 21,2 & 23,6 & 25,8 \\
\hline 6,0 & 16,3 & 17,4 & 18,8 & 22,5 & 25,1 & 27,9 \\
\hline 6,5 & 17,1 & 18,2 & 19,9 & 24,0 & 26,7 & 29,8 \\
\hline 7,0 & 18,0 & 19,3 & 20,6 & 25,3 & 28,4 & 31,8 \\
\hline 8,0 & 20,0 & 21,2 & 23,0 & 28,5 & 32,2 & 36,4 \\
\hline 9,0 & 21,9 & 23,3 & 25,4 & 32,0 & 36,4 & 41,0 \\
\hline 10,0 & 23,9 & 25,6 & 28,0 & 36,0 & 41,1 & 47,0 \\
\hline 11,0 & 26,0 & 28,0 & 31,1 & 40,3 & 46,0 & 53,5 \\
\hline 12,0 & 28,4 & 31,4 & 35,2 & 45,4 & 51,3 & 58,8 \\
\hline 13,0 & 32,0 & 35,3 & 40,0 & 51,8 & 56,8 & 64,2 \\
\hline 14,0 & 36,1 & 39,9 & 44,0 & 55,0 & 60,9 & 70,0 \\
\hline 15,0 & 39,4 & 43,7 & 47,6 & 58,0 & 63,9 & 73,6 \\
\hline 16,0 & 42,4 & 46,8 & 51,0 & 61,0 & 66,2 & 76,1 \\
\hline 17,0 & 45,2 & 48,4 & 52,4 & 62,0 & 68,0 & 79,0 \\
\hline
\end{tabular}


И.Ю. Юров, С.Г. Ворсанова, В.Ю. Воинова, М.И. Чурносов, Ю.Б. Юров

\section{Центильные величины окружности головы (см) девочек (0 мес. - 17 лет)}

\begin{tabular}{|c|c|c|c|c|c|c|}
\hline \multirow{2}{*}{ Возраст } & \multicolumn{6}{|c|}{ Центили } \\
\hline & 3 & 10 & 25 & 75 & 90 & 97 \\
\hline 0 мес. & 32,0 & 33,0 & 34,0 & 35,5 & 36,4 & 37,0 \\
\hline 1 & 33,8 & 34,8 & 36,0 & 38,0 & 38,8 & 39,5 \\
\hline 2 & 35,6 & 36,3 & 37,4 & 39,8 & 40,6 & 41,4 \\
\hline 3 & 36,9 & 37,7 & 38,5 & 41,3 & 42,2 & 43,0 \\
\hline 4 & 38,2 & 38,9 & 39,7 & 42,4 & 43,3 & 44,2 \\
\hline 5 & 39,2 & 39,9 & 40,7 & 43,5 & 44,4 & 45,4 \\
\hline 6 & 40,1 & 40,8 & 41,5 & 44,3 & 45,3 & 46,3 \\
\hline 7 & 41,0 & 41,7 & 42,5 & 45,3 & 46,2 & 47,3 \\
\hline 8 & 41,6 & 42,3 & 43,2 & 45,9 & 46,9 & 48,0 \\
\hline 9 & 42,4 & 42,9 & 43,7 & 46,6 & 47,6 & 48,5 \\
\hline 10 & 42,8 & 43,5 & 44,3 & 47,2 & 48,3 & 49,2 \\
\hline 11 & 43,2 & 43,9 & 44,8 & 47,8 & 48,7 & 49,6 \\
\hline 12 & 43,5 & 44,2 & 45,0 & 48,2 & 49,2 & 50,1 \\
\hline 15 & 44,2 & 45,1 & 45,9 & 48,7 & 49,6 & 50,5 \\
\hline 18 & 44,9 & 45,7 & 46,4 & 49,0 & 49,9 & 50,9 \\
\hline 21 & 45,4 & 46,1 & 46,9 & 49,4 & 50,2 & 51,2 \\
\hline 24 & 46,0 & 46,6 & 47,3 & 49,7 & 50,5 & 51,5 \\
\hline 27 & 46,5 & 47,0 & 47,8 & 50,0 & 50,7 & 51,8 \\
\hline
\end{tabular}


Цитогенетические, молекулярные и клинические основы генетически обусловленных болезней

\begin{tabular}{|c|c|c|c|c|c|c|}
\hline 30 & 47,0 & 47,5 & 48,0 & 50,4 & 51,0 & 52,0 \\
\hline 33 & 47,3 & 47,9 & 48,4 & 50,6 & 51,4 & 52,4 \\
\hline 36 & 47,6 & 48,1 & 48,6 & 51,0 & 51,7 & 52,7 \\
\hline 3,5 лет & 47,8 & 48,3 & 49,0 & 51,5 & 52,3 & 53,2 \\
\hline 4,0 & 48,0 & 48,6 & 49,3 & 51,9 & 52,7 & 53,5 \\
\hline 4,5 & 48,3 & 48,9 & 49,7 & 52,3 & 52,9 & 53,8 \\
\hline 5,0 & 48,5 & 49,1 & 50,0 & 52,5 & 53,2 & 54,0 \\
\hline 5,5 & 48,8 & 49,4 & 50,2 & 52,7 & 53,5 & 54,2 \\
\hline 6,0 & 49,0 & 49,6 & 50,3 & 52,8 & 53,7 & 54,5 \\
\hline 6,5 & 49,2 & 49,8 & 50,6 & 53,0 & 53,9 & 54,6 \\
\hline 7,0 & 49,4 & 50,0 & 50,7 & 53,3 & 54,1 & 54,8 \\
\hline 8,0 & 49,7 & 50,3 & 51,0 & 53,6 & 54,4 & 55,2 \\
\hline 9,0 & 50,0 & 50,6 & 51,3 & 53,9 & 54,6 & 55,4 \\
\hline 10,0 & 50,3 & 50,8 & 51,5 & 54,1 & 54,8 & 55,6 \\
\hline 11,0 & 50,4 & 51,0 & 51,7 & 54,3 & 55,0 & 55,8 \\
\hline 12,0 & 50,5 & 51,2 & 51,9 & 54,6 & 55,2 & 56,1 \\
\hline 13,0 & 50,6 & 51,4 & 52,0 & 54,8 & 55,5 & 56,4 \\
\hline 14,0 & 50,7 & 51,5 & 52,1 & 55,0 & 55,7 & 56,6 \\
\hline 15,0 & 50,8 & 51,6 & 52,2 & 55,2 & 55,9 & 56,7 \\
\hline 16,0 & 50,9 & 51,7 & 52,3 & 55,3 & 56,0 & 56,9 \\
\hline 17,0 & 51,0 & 51,8 & 52,4 & 55,4 & 56,1 & 57,1 \\
\hline
\end{tabular}


И.Ю. Юров, С.Г. Ворсанова, В.Ю. Воинова, М.И. Чурносов, Ю.Б. Юров

Центильные величины окружности груди (см)

девочек (0 мес. - 17 лет)

\begin{tabular}{|c|c|c|c|c|c|c|}
\hline \multirow{2}{*}{ Возраст } & \multicolumn{6}{|c|}{ Центили } \\
\hline & 3 & 10 & 25 & 75 & 90 & 97 \\
\hline 0 мес. & 30,8 & 31,8 & 33,2 & 35,7 & 36,4 & 37,0 \\
\hline 1 & 32,9 & 34,0 & 35,3 & 37,4 & 38,1 & 39,0 \\
\hline 2 & 34,6 & 35,7 & 37,2 & 39,1 & 40,0 & 40,9 \\
\hline 3 & 36,2 & 37,3 & 38,7 & 40,5 & 41,2 & 42,8 \\
\hline 4 & 38,1 & 39,1 & 40,4 & 42,1 & 43,2 & 44,3 \\
\hline 5 & 39,4 & 40,5 & 41,7 & 43,5 & 44,6 & 45,8 \\
\hline 6 & 40,6 & 41,6 & 42,9 & 44,9 & 46,1 & 47,2 \\
\hline 7 & 41,8 & 42,8 & 44,0 & 46,0 & 47,2 & 48,5 \\
\hline 8 & 42,8 & 43,7 & 44,9 & 46,9 & 48,3 & 49,8 \\
\hline 9 & 43,6 & 44,5 & 45,6 & 47,8 & 49,3 & 51,0 \\
\hline 10 & 44,3 & 45,2 & 46,2 & 48,1 & 50,1 & 52,0 \\
\hline 11 & 45,0 & 45,8 & 46,8 & 49,3 & 50,8 & 52,7 \\
\hline 12 & 45,5 & 46,3 & 47,3 & 49,9 & 51,4 & 53,3 \\
\hline 15 & 46,4 & 47,2 & 48,1 & 50,8 & 52,3 & 53,9 \\
\hline 18 & 47,1 & 47,8 & 48,7 & 51,3 & 52,9 & 54,5 \\
\hline 21 & 47,5 & 48,2 & 49,1 & 51,9 & 53,5 & 55,0 \\
\hline 24 & 47,8 & 48,6 & 49,5 & 52,5 & 54,0 & 55,6 \\
\hline 27 & 47,9 & 48,8 & 49,8 & 53,0 & 54,5 & 56,2 \\
\hline 30 & 48,0 & 48,9 & 49,9 & 53,3 & 55,0 & 56,8 \\
\hline 33 & 48,1 & 49,0 & 50,1 & 53,7 & 55,5 & 57,2 \\
\hline
\end{tabular}


Цитогенетические, молекулярные и клинические основы генетически обусловленных болезней

\begin{tabular}{|c|c|c|c|c|c|c|}
\hline 36 & 48,2 & 49,1 & 50,3 & 54,0 & 56,0 & 57,6 \\
\hline 3,5 лет & 48,6 & 49,5 & 51,0 & 54,3 & 56,2 & 57,8 \\
\hline 4,0 & 49,2 & 50,4 & 51,6 & 55,1 & 56,9 & 58,6 \\
\hline 4,5 & 50,4 & 51,0 & 52,3 & 55,9 & 57,8 & 59,7 \\
\hline 5,0 & 50,9 & 51,6 & 53,0 & 56,9 & 58,8 & 61,0 \\
\hline 5,5 & 51,5 & 52,2 & 53,9 & 57,8 & 60,0 & 62,2 \\
\hline 6,0 & 52,3 & 53,0 & 54,8 & 58,6 & 61,2 & 63,6 \\
\hline 6,5 & 53,2 & 53,8 & 55,5 & 59,8 & 62,4 & 64,8 \\
\hline 7,0 & 54,7 & 54,6 & 56,3 & 61,0 & 63,7 & 66,6 \\
\hline 8,0 & 56,3 & 56,3 & 58,2 & 64,5 & 67,6 & 70,6 \\
\hline 9,0 & 56,7 & 58,0 & 60,0 & 68,1 & 71,4 & 75,1 \\
\hline 10,0 & 58,0 & 60,1 & 62,0 & 71,3 & 75,5 & 78,8 \\
\hline 11,0 & 59,8 & 62,2 & 64,4 & 74,5 & 78,6 & 82,3 \\
\hline 12,0 & 61,9 & 64,5 & 67,2 & 77,6 & 81,9 & 86,0 \\
\hline 13,0 & 64,3 & 66,8 & 70,0 & 80,9 & 85,0 & 88,0 \\
\hline 14,0 & 67,0 & 69,6 & 73,0 & 83,5 & 87,6 & 91,0 \\
\hline 15,0 & 70,0 & 72,9 & 76,2 & 85,5 & 89,3 & 92,6 \\
\hline 16,0 & 73,0 & 75,9 & 78,8 & 87,1 & 90,6 & 93,9 \\
\hline 17,0 & 75,4 & 78,0 & 80,7 & 88,0 & 91,1 & 94,6 \\
\hline
\end{tabular}

Авторы приносят особую благодарность к.б.н. Куринной О.С. - старшему научному сотруднику лаборатории молекулярной цитогенетики нервно-психических заболеваний ОСП НИКИ педиатрии им. академика Ю.Е. Вельтищева ФГБОУ ВО РНИМУ им. Н.И. Пирогова Минздрава России за неоценимую помощь в подготовке учебного пособия, а также выражают благодарность к.б.н., с.н.с. Колотию А.Д. и к.б.н., н.с. Зеленовой М.А. за техническую помощь. 


\author{
Юров Иван Юрьевич \\ Ворсанова Светлана Григорьевна \\ Воинова Виктория Юрьевна \\ Чурносов Михаил Иванович \\ Юров Юрий Борисович
}

\title{
ЦИТОГЕНЕТИЧЕСКИЕ, МОЛЕКУЛЯРНЫЕ И КЛИНИЧЕСКИЕ ОСНОВЫ ГЕНЕТИЧЕСКИ ОБУСЛОВЛЕННЫХ БОЛЕЗНЕЙ
}

Учебное пособие

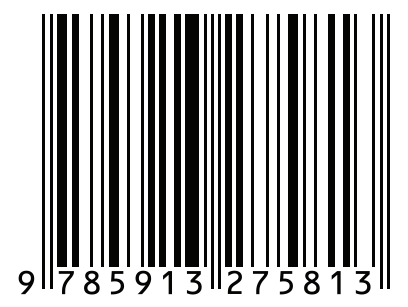

Технический редактор Кулакова Г.А.

Подписано в печать 17.04.2019

Бумага офсетная.

Гарнитура NewtonC

Формат 60×84 1/16

Печать трафаретная. Печ. л. 10,25.

Тираж 500 экз. Заказ № 012-19.

Отпечатано в типографии ИД «Академия Естествознания», 440026, г. Пенза, ул. Лермонтова, 3 